"IT'S ABOUT BEING GENUINE AND HAVING HEART": LATINOS' PERSPECTIVES OF COLLEGE COUNSELING

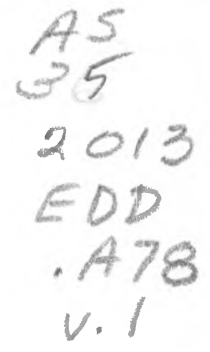

A dissertation submitted to the faculty of San Francisco State University In partial fulfillment of The Requirements for

Doctor of Education

In

Educational Leadership

by

Blanca Estela Arteaga

San Francisco, California

May 2013 
Copyright by

Blanca Estela Arteaga

2013 


\section{CERTIFICATION OF APPROVAL}

I certify that I have read "It's About Being Genuine and Having Heart": Latinos' Perspectives of College Counseling by Blanca Estela Arteaga, and that in my opinion this work meets the criteria for approving a dissertation submitted in partial fulfillment of the requirements for the degree: Doctor of Education in Educational Leadership at San Francisco State University.

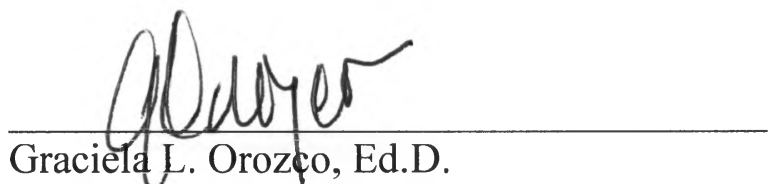

Associate Professor \& School Counseling Coordinator

San Francisco State University

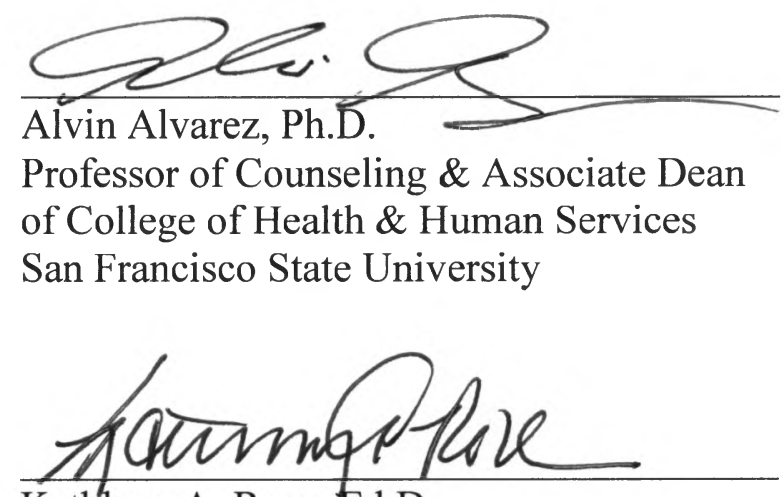

Kathleen A. Rose, Ed.D.

Executive Vice President \& Chief Instruction Officer Gavilan College 


\title{
"IT'S ABOUT BEING GENUINE AND HAVING HEART": LATINOS' PERSPECTIVES OF COLLEGE COUNSELING
}

\author{
Blanca Estela Arteaga \\ San Francisco State University \\ 2013
}

Latino students represent the fastest-growing population in the state of California and in the United States as well as the largest number in the California Community College (CCC) system. Unfortunately, compared to other ethnic groups, Latino community college students continue to lag academically. Given the scarce research related to community college students and community college counseling services, this study explored how 26 first-generation, lowincome, Latino community college students perceived, negotiated, and developed a relationship with their community college counselor. This study also extended the literature on (a) students' motives for pursuing higher education; (b) the role of la familia [the family] in supporting students to attend college; (c) Latino students' high school counseling experiences, and (d) the importance of community college counseling services in assisting and motivating students to reach transfer and graduation. This study proposes a set of counseling guidelines that can assist in relationship-building between students and community college counselors which could be termed as, relational etiquette. In addition, based on participants' consejos [advice] for community college counselors, participants' description of the characteristics of un buen consejero [a good counselor], and other published research related to students' counseling experiences, this study provides a list of community college students' preferred counselor characteristics and recommendations for the improvement of community college counseling services.

I certify that the Abstract is a correct representation of the content of this dissertation.

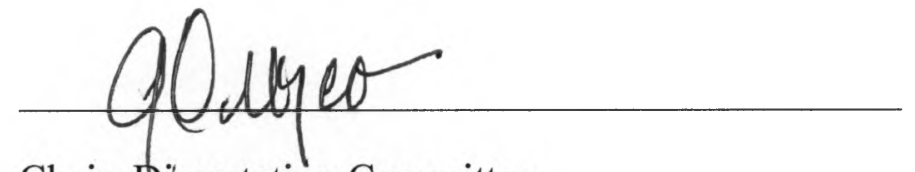

Chair, Dissertation Committee

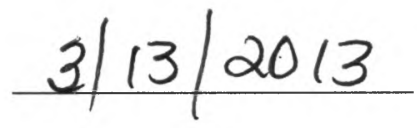

Date 


\section{ACKNOWLEDGEMENTS}

Completing this dissertation symbolizes esfuerzo, dedicación, perseverancia, sacrificio, and a personal commitment to student advocacy. I could not have completed this dissertation without the love and support of various people in my life, thus I would like to extend my gratitude. To Miguel Arteaga, el amor de mi vida, no podría haber logrado esta meta sin tu amor y tu apoyo incondicional. Le doy gracias a Dios por tenerte a mi lado. ¡Te amo! To Saileen Arteaga, mi princesa, gracias por siempre recibirme con los brazos abiertos los días y fines de semana que llegaba a casa "ya que se había metido el sol" porque estaba haciendo tarea o en la escuela. ¡Te amo princesa hermosa! To Martha Mustafa, mi mamá y amiga, gracias por su apoyo, cariño, y su disposición a cuidar a Saileen cuando lo necesitaba. I love you má! To mis tíos Rosy Ramirez and Marco Ramirez and to the rest of mi familia, gracias por su motivación y sus consejos. ¡Los quiero mucho! To AJ Winckler, thank you for the encouragement, countless hours of study-time together, and hilarious conversations during the long car rides. I'm so glad I met you! To Dr. Donohue-Mendoza, thank you for being my mentor, cheerleader, and editor. With your encouragement, I overcame many doubts and have grown as a person. To Dr. Orozco, muchísimas gracias for always assisting me with any concerns through email, phone, and/or our lengthy monthly conferences. Gracias for your invaluable guidance and for your supervision of my studies as my dissertation chair. To Dr. Rose and Dr. Alvarez, thank you for your time and dedication to my dissertation, my learning, and my growth as a practitioner. To the 12 ETCCD instructors, thank you for allowing me to recruit participants in your classroom and for being willing to provide extra credit to study participants. Finally, to the 26 Latino students who participated in this study, thank you for your time and for your confianza in sharing your life struggles and counseling experiences with me. This study could not have been possible without your voice. Because of you, I am committed to applying relational etiquette in my practice as a community college counselor and to continue advocating for students. 


\section{TABLE OF CONTENTS}

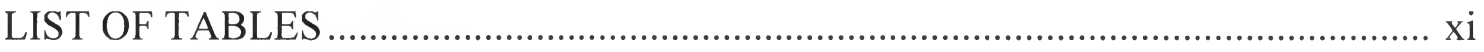

LIST OF FIGURES .....................................................................................

LIST OF APPENDICES …………………………..............................................

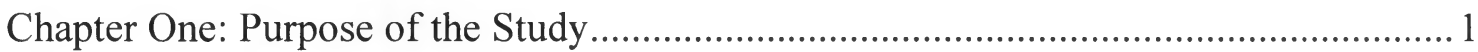

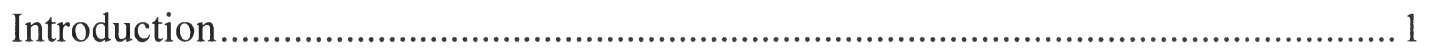

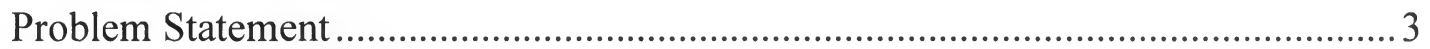

Purpose of the Study ................................................................................. 4

Study Justification.........................................................................................

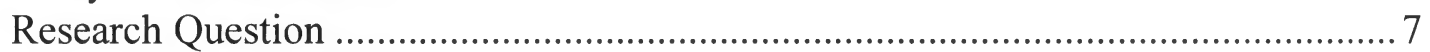

Operational Definitions of Key Terms .............................................................. 8

Statement of Delimitations and Scope of Study ……….......................................... 12

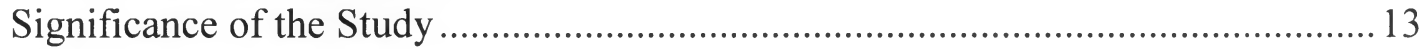

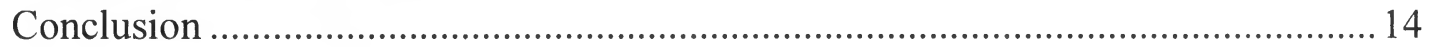

Chapter Two: Literature Review ……………………........................................ 15

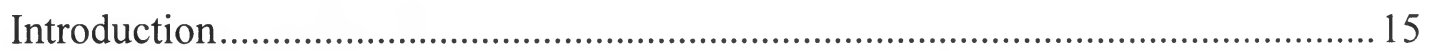

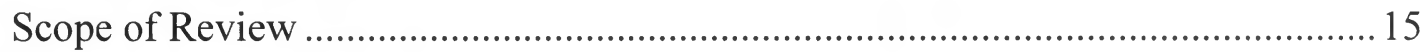

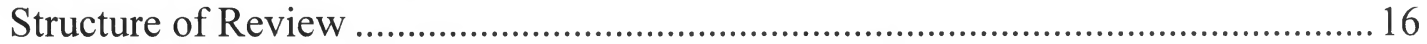

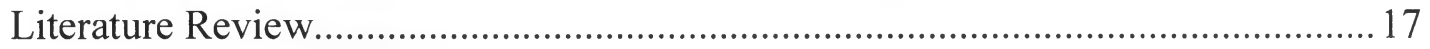

Familismo and parental support promote students' pursuit for college.............. 17

Defining community college counseling and its core functions..........................22

The role of community college counselors in the matriculation process.............25

The role of community college counselors in support and advocacy.................28

High school counseling services........................................................................ 30

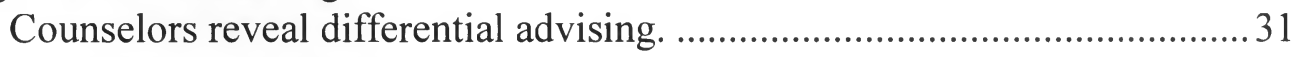

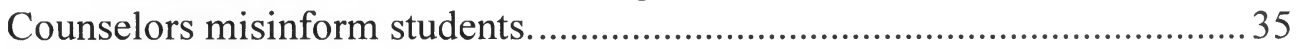

Counselors rush through the counseling process........................................... 37

Community college counseling services........................................................... 40

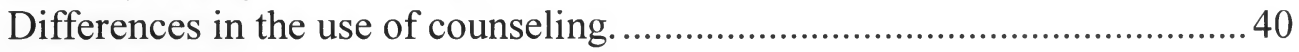

Inaccessibility to counselors and inadequate advisement.............................. 42

High counselor-to-student ratios also present a major barrier for students. . 43

Categorical support programs.................................................................... 47

The importance of the student-counselor relationship........................................50 


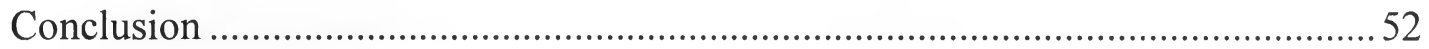

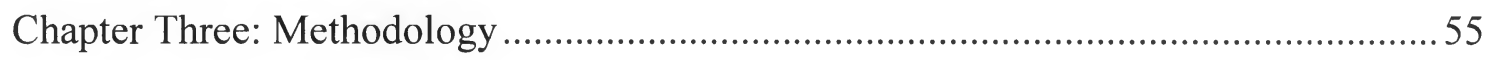

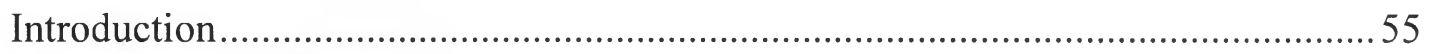

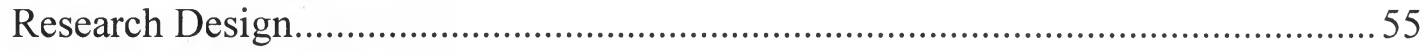

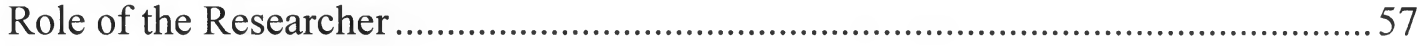

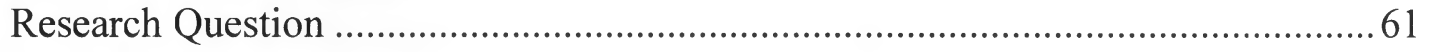

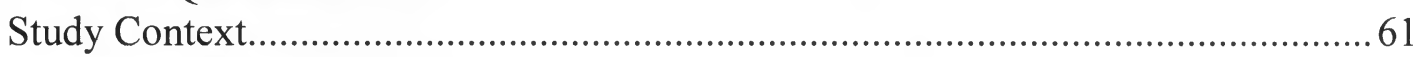

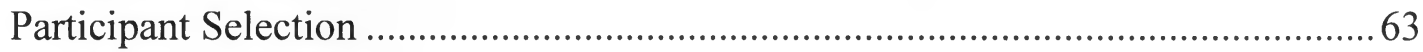

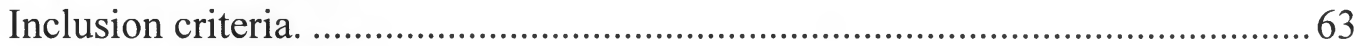

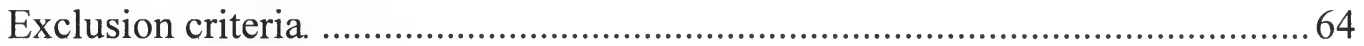

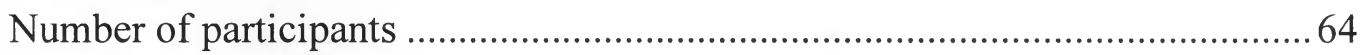

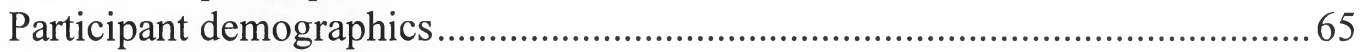

Ethics and Protection of Human Subjects............................................................ 70

Institutional permission............................................................................... 70

Review board approval. ............................................................................... 70

Participant permission................................................................................ 71

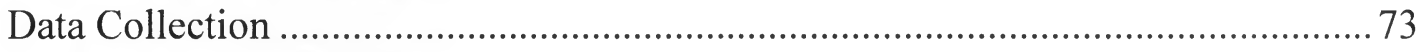

Participant recruitment ................................................................................ 73

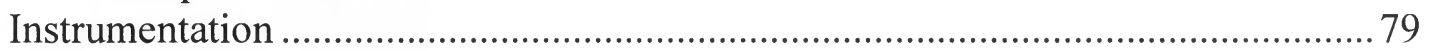

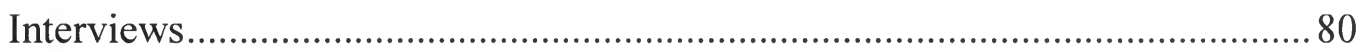

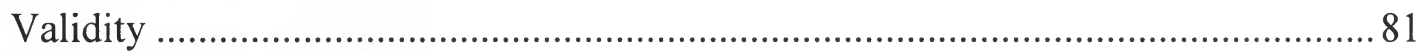

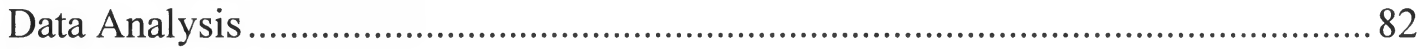

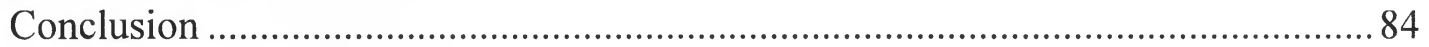

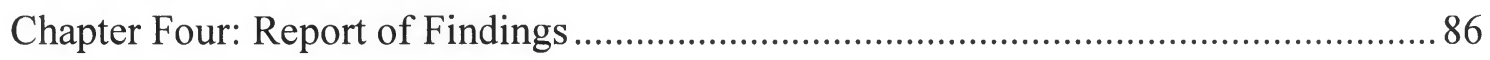

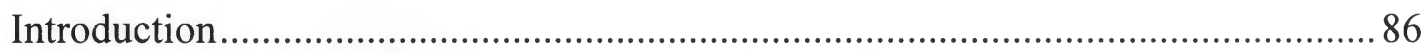

Students' Motivación [Motivation] to Attend College ………...................................8 87

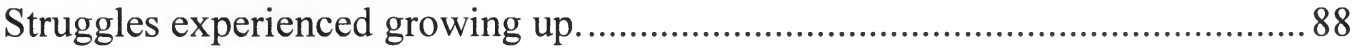

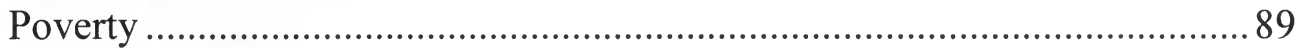

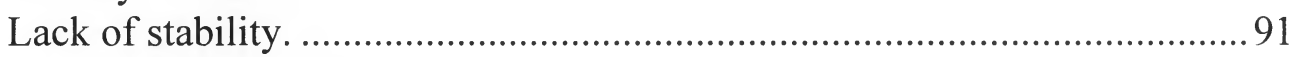

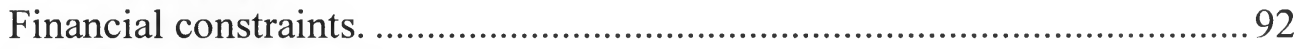

Parental sacrifices and advice. ..................................................................... 92

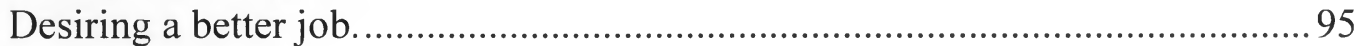

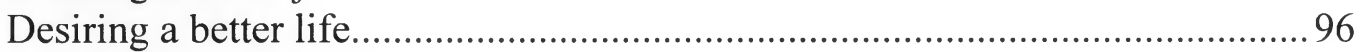

A life better than the life growing up........................................................96

A life with better communication. ...........................................................97

A life with independence. …………....................................................... 98

A life as a role model.................................................................................. 98 
Students' Consejos [Advice] for Community College Counselors .......................... 158

Care more about students.......................................................................... 160

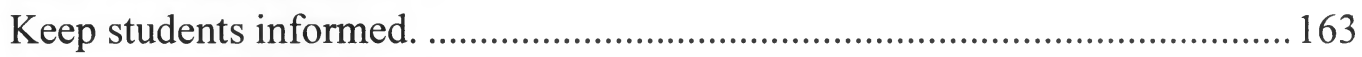

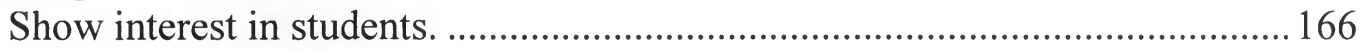

Increase bilingual counseling services............................................................. 168

Provide consistency in counseling and information. ......................................... 171

Theoretical Model for Students' Perspectives of Community College Counseling173

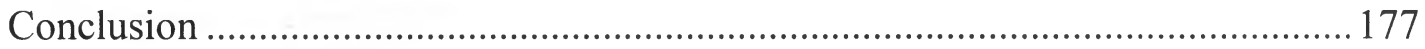

Chapter Five: Discussion and Recommendations..................................................... 183

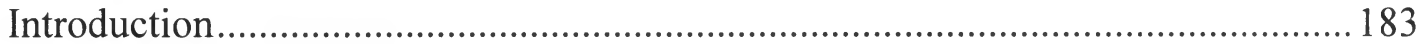

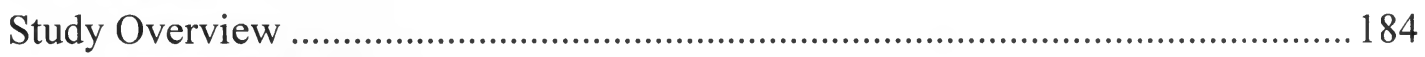

Purpose of the study ...................................................................................... 184

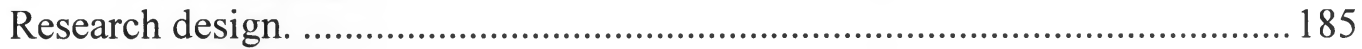

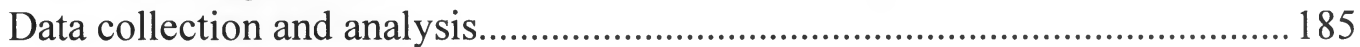

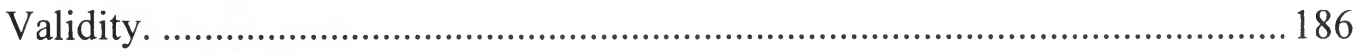

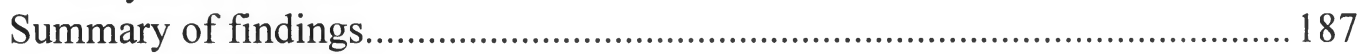

Interpretation of Findings ............................................................................... 192

Developing a grounded theory model to explain first-generation, low-income,

Latino students' perspectives of community college counseling services......... 192

Defining Latino community college students..................................................... 193

Emphasizing counseling services for the success of Latinos............................. 195

Latinos' perceptions of community college counseling services. ...................... 198

Promoting personalismo and positive counseling relationships for Latinos. ...207

Listening to Latinos' consejos [advice] to improve counseling services. ........210

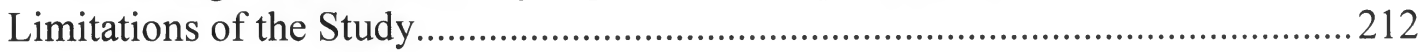

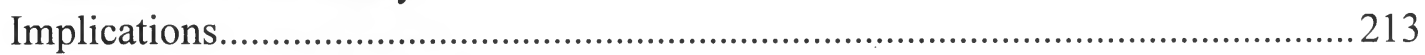

Recommendations for Action .........................................................................2215

Apply relational etiquette to community college counseling..........................2.216

Re-design the delivery of counseling services................................................220

High-touch versus low-touch counseling services.......................................221

Employ a case management approach to counseling...................................222

Utilize peer advisors. ............................................................................... 225

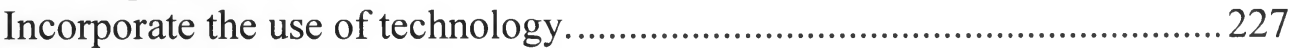

Analyze the evaluation process in counseling departments...............................223

Develop vision and commitment to multiculturalism and social justice. .........237

Examine counselor hiring practices. .................................................................239

Utilize community college students' preferred counselor characteristics. . 240

Analyze the counselor interview protocol................................................... 242 
Provide ongoing counselor professional development. ................................2245

Recommendations for Further Study ........................................................ 248

Reflections on the Research Process.................................................................2251

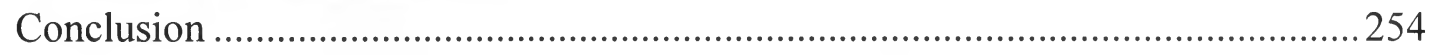

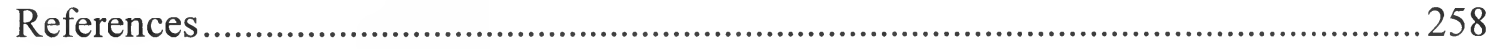

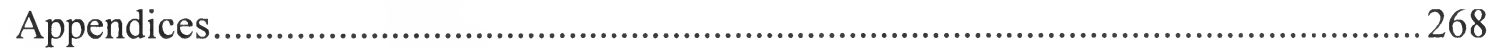




\section{LIST OF TABLES}

Table

Page

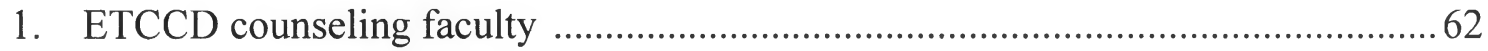

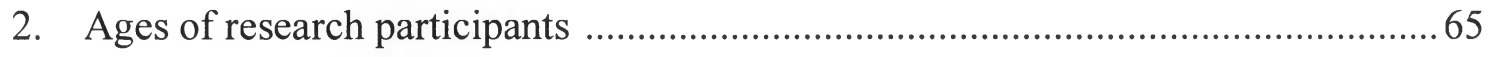

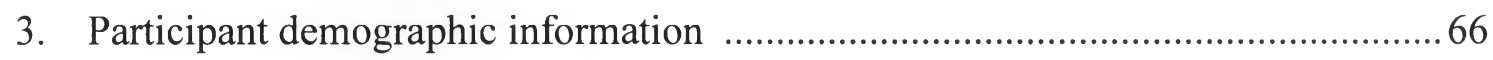

4. Family composition of participants who have children ......................................66

5. Enrollment status of participants who have children ..........................................67 67

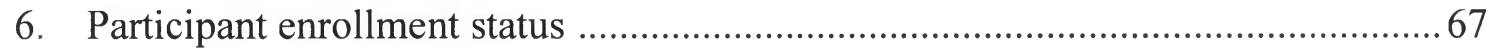

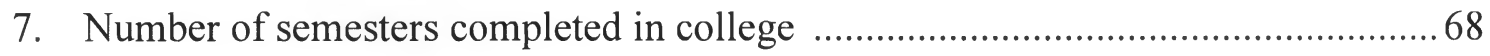

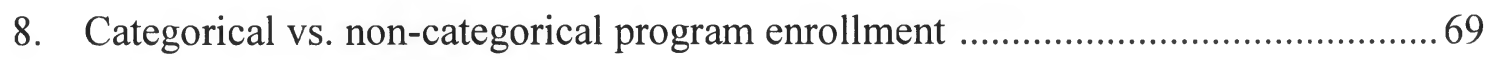

9. Number of counseling appointments scheduled per semester ..............................70

10. Participants' motivación [motivation] to attend college ........................................ 88

11. Support of la familia [the family] in students' pursuit of higher education ......... 101

12. Barriers of la familia [the family] to providing academic support ....................... 109

13. Importance of community college counseling services .................................... 113

14. Role of community college counselors …................................................... 116

15. Characteristics of un buen consejero [a good counselor] in community college .118

16. Positive community college counseling experiences ........................................ 123

17. Participants' community college counseling experiences ................................. 124

18. Participants' positive community college counseling experiences in support programs vs. no support programs .......................................................... 124

19. Participants' positive community college counseling experiences with general counselors 
20. Number of participants who had at least one negative counseling experience with categorical counselors and general counselors .................................................. 138

21. Negative community college counseling experiences …….................................. 139

22. Hindrances to seeking community college counseling services ........................... 152

23. Participants' hindrances to seeking counseling in support programs vs no support

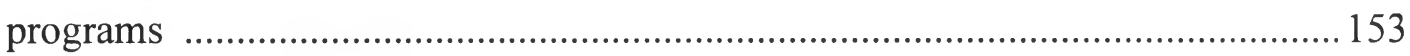

24. Participants' consejos [advice] for community college counselors .......................159

25. ETCCD categorical program funding allocations and counselor-to-student ratios $2011 / 2012$ 202

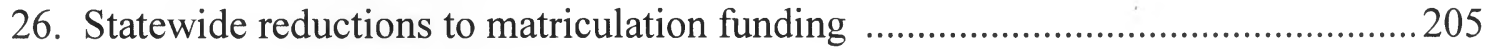

27. ETCCD reductions to off-contract counseling hours .............................................206

28. Guidelines for applying relational etiquette in community college counseling ...219

29. Community college students' preferred counselor characteristics 


\section{LIST OF FIGURES}

Figure

Page

1. Participants' majors

.68

2. Theoretical model of how first-generation, low-income, Latino students perceive, negotiate, and develop a relationship with their community college counselor .... 174

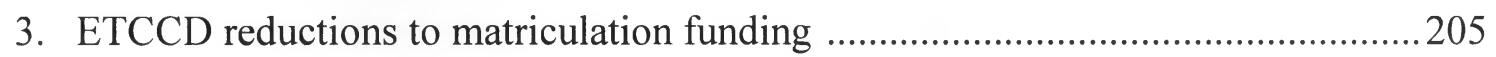




\section{LIST OF APPENDICES}

Appendix

Page

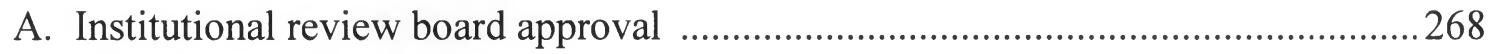

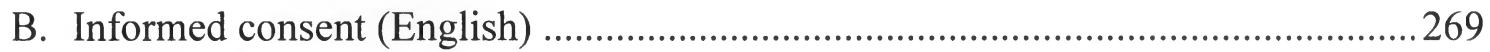

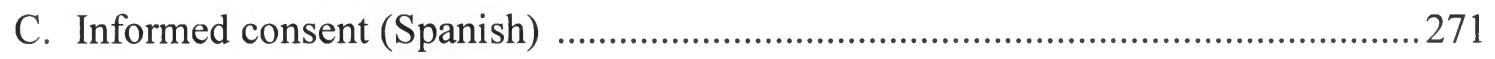

D. Permission agreement to contact instructor (English) .......................................273

E. Permission agreement to contact instructor (Spanish) ....................................2274

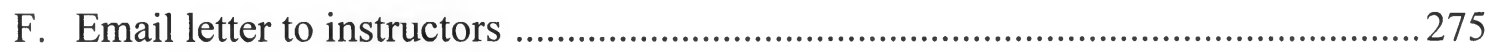

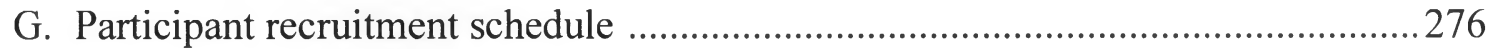

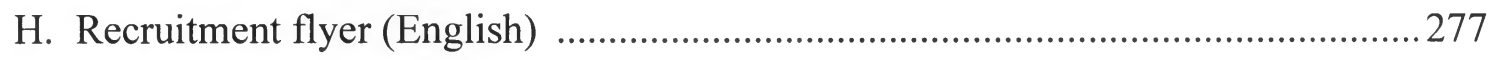

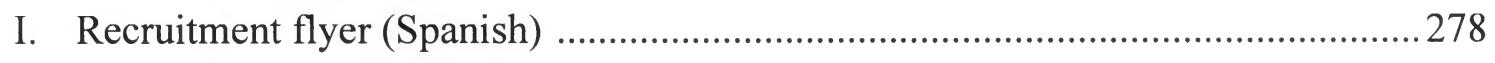

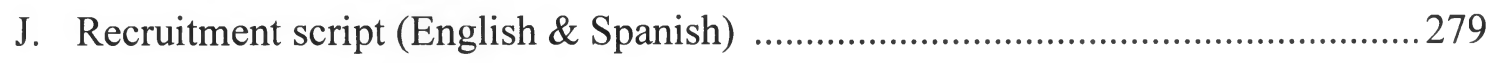

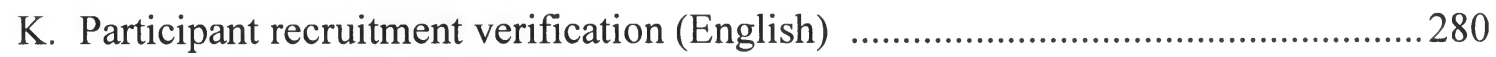

L. Participant recruitment verification (Spanish) .................................................... 281

M. Script for participants put on a waitlist (English \& Spanish) ..............................2282

N. Script for ineligibility to participate in the study (English \& Spanish) .................283

O. Semi-structured in-depth interview protocol (received counseling) .......................228

P. Semi-structured in-depth interview protocol (no counseling received)..................288

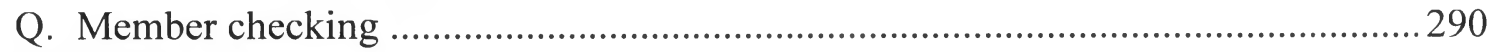

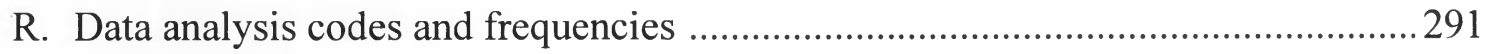

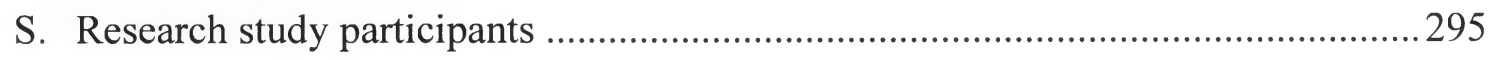




\section{Chapter One: Purpose of the Study}

\section{Introduction}

As a first-generation, low-income, Latina, coming to college is really hard and it takes a lot of sacrifice because I don't have a lot of financial help . . . Sometimes I think, 'I need to work more because I need money to pay the bills, but my education is also important.' So, it's like 'which way do I go?' It's also hard because sometimes I feel really lost . . like when I first came, I didn’t know how to read the catalog, how to choose my classes, or what the numbers meant. It was confusing even to fill out a registration card . . . Since my parents and none of my family members went to college, they can't help me. So I feel like I'm on my own to get all the research about general ed, what classes to take, what's going to benefit me to transfer, and what I want to do. So this whole college thing is like 'OH MY GOD!' (Jessica S., 9/12/12, Question 1, 20). Jessica S. is one of 2.5 million students who attend a California Community College (CCC) to gain access and education in one of 112 campuses around the state (Sengupta \& Jepsen, 2006). The CCC system is the world's largest system of higher education. According to the Community College League of California (CCLC) (2012b), in 2008-2009 out of every 1,000 members of the population, 75 attended a CCC representing over $87 \%$ of undergraduate students and $24 \%$ of community college students nationwide. The CCC Chancellor's Office (CCCCO) (2009) indicated many CCC students are economically disadvantaged, immigrants, foster youth, veterans, 
employees, parents, disabled, and face personal and medical challenges that may hinder their ability to reach their educational objectives.

Among the many groups of students enrolled within the CCC system, Latino students make up the largest number (34\%) compared to $33 \%$ of Caucasian, $12 \%$ of Asian, and $8 \%$ of African-American students (CCLC, 2012). Latinos students also make up the fastest-growing population in the state of California and in the United States (Shulock \& Moore, 2007). According to the National Center for Educational Statistics (NCES) (2011), between 1976 and 2009, the percentage of Latino college students increased from $3 \%$ to $12 \%$ while the percentage of Caucasian students dropped from $83 \%$ to $62 \%$. Projections from the California Postsecondary Education Commission (CPEC) (2009) suggested that Latino student enrollment in CCC will increase by $40 \%$ over the next ten years while the percentage of Caucasian students will remain stable. This increase in Latino student enrollment within the CCC system is consistent with their growth in the United States. Between 2000 and 2010, for example, the Latino population grew by $43 \%$ representing $38 \%$ of the population in CA and $16 \%$ of the total United States population (Humes, Jones, \& Ramirez, 2011). By 2040, it is expected that three Latino children will be born for every Caucasian child born (Lay, 2010). Although Latino students represent the largest number of students attending CCC and the fastest growing population in the United States, they represent the smallest number of students who achieve degree completion. 


\section{Problem Statement}

In California, completion rates for Latino community college students are dismal. Bailey and Morest (2006) confirmed that in the CCC system, Latino students had lower completion rates (18\%) compared to their Caucasian (27\%) and Asian (33\%)

peers. Furthermore, Moore and Shulock (2010) stated that only $16 \%$ of working age (25-64) Latino adults have a college degree (associate or higher) compared to $50 \%$ of Caucasian working age adults. In fact the researchers found that in a six-year period, only $11 \%$ of degree seekers were awarded an associate degree (Moore \& Shulock, 2010). Within the CCC system, success rates for Latino students also vary by CC district and location.

El Toro Community College District (ETCCD) is located in the central coast of California and is one of $112 \mathrm{CCC}$ serving approximately 6,000 students of which more than half are Latino (54\%) (CCCCO, 2012a). Similar to the population trends in the state of California, ETCCD has seen an increase in the Latino students. Over the last seven years, the Latino student population grew from $48 \%$ to $54 \%$ while the Caucasian student population decreased from $39 \%$ to $32 \%$ (CCCCO, 2012a). Although Latino students represent the majority of the population at ETCCD, two studies conducted by the ETCCD campus researcher revealed that completion rates for this student population are of great concern. After tracking a cohort of 675 students over six academic years (2001/2002 to $2006 / 2007)$, the first study revealed that only $18 \%$ of Latino students completed an associate degree (Scott \& Perry, 2010). Further analyzing 
the Latino student population, the second study tracked Latino students over a threeyear period (2006-2009) and revealed that only 3\% of Latino students completed an associate degree compared to $29 \%$ of Asian, $9 \%$ of Caucasian, and $6 \%$ of AfricanAmerican students (Scott \& Perry, 2010). Latinos represent the fastest growing population in California and will likely represent half of the United States population. If their success rate continues to lag behind other student populations within the CCC system, the state will encounter (a) inequality, (b) political and social instability, and (c) economic decline (Lay, 2010).

\section{Purpose of the Study}

The purpose of this study is to gain a deeper understanding of how firstgeneration, low-income, Latino community college students perceive, negotiate (interpret or try to make meaning of), and develop a relationship with their community college counselor. Community college counselors provide assistance and guidance to students in resolving academic, career, vocational, transfer, personal, and crisis situations in the CCC setting (Academic Senate for California Community Colleges, 2003). In the last 30 years, researchers have recognized the importance and the need for counselors to assist students in reaching their educational goals (Board of Governors, 1992; Croquett, 1978; Pulliams, 1990; Vasconcellos, 1988; Wiseman \& Messitt, 2010). Counseling services are especially important for Latino students as they represent the fastest-growing population and tend to face many personal and academic challenges that make them less likely than other demographic groups to reach college completion. 
Latino students are likely to: (1) come from a poor socioeconomic background, (2) be first-generation students, (3) have poor college preparatory experiences (4) face challenges that interfere with their academic achievement, and (5) represent the smallest number of students who reach degree completion (associate or higher) (Davis, 2010; Gándara, 2010; Moore \& Shulock, 2010; Pulliams, 1990).

\section{Study Justification}

Latinos are the fastest-growing population in CA and in the U.S. (Shulock \& Moore, 2007). In fact, CPEC (2009) projected that in the next ten years it is likely that Latinos will make up half of the student population. As the Latino student population continues to increase within the CCC system, the state of CA, and the United States, reducing the achievement gap in their completion rate is a critical social justice and equity issue as it portends inequitable opportunities, decreased civic participation, lower tax revenues, and potentially grave consequences for the economy and the social structure of the United States (Gándara, 1995; Lay, 2010; Museus \& Ravello, 2010; Woodlief \& Olson, 2002).

To date, there has been minimal research conducted in the area of Latino CC students. Research is even scarcer in the specific area of community college counseling for Latino students. Current research related to counseling services has generally focused on the high school counseling experiences of Latino students, thus leaving a gap in the literature about the counseling experiences, perceptions, and needs of Latino community college students. The gap in the literature is especially pronounced with 
respect to the college experiences of Latino, low-income, and first-generation student populations. Exploring the experiences of this student population is significant because the CCC system is expected to enroll an increased number of Latino students, firstgeneration students, and students from low-income families (CPEC, 2009). Further investigation is needed to understand: (1) Latino students' needs as they navigate the system of higher education, (2) how student-counselor relationships motivate students to persist toward degree completion, and (3) how promising counseling practices can be used to support Latino students and ultimately improve the CCC counseling field. Exploring the counseling experiences of first-generation, low-income, Latino community college students will fill the gap in the literature and shed light on the importance of counseling in motivating students to retain, persist, and complete their education objectives.

As a practitioner-scholar and a current community college counselor, the findings can assist the researcher and other CCC counselors in gaining greater knowledge about the needs of first-generation, low-income, Latino students. By understanding Latino students' needs, community college counselors will be able to examine their own counseling activities and improve upon their practice in serving this student population and other marginalized groups. Using students' perspectives will inform institutional practices including, (a) organizational culture, (a) hiring, (b) evaluation, and (c) counselor professional development. Overall, the findings will be useful for (1) informing the field and the CCC system about promising counseling 
practices that assist Latino community college students to academically succeed, and (2) redesign the delivery of counseling and student services to accommodate the mandates of the Student Success Act of 2012 (SB1456) (Lowenthal \& Liu, 2012) using diminishing resources in a more creative way.

\section{Research Question}

How do first-generation, low-income, Latino students perceive, negotiate (interpret or try to make meaning of), and develop a relationship with their community college counselor? Gathering information about Latino students' perceptions and experiences with community college counseling services will provide institutions with greater understanding about: (1) Latino students' needs as they navigate the system of higher education, (2) how student-counselor relationships motivate students to persist toward degree completion, and (3) how promising counseling practices can be used to support Latino students and continuous improvement in the CCC counseling field. The researcher proposed that students who perceived having positive counseling experiences and student-counselor relationships with their community college counselor would be more motivated to persist toward the achievement of their educational objectives than students who perceived having negative counseling experiences and student-counselor relationships. She also proposed that the current community college counseling model may have to be restructured to meet the diverse needs of an evolving CCC student population. 


\section{Operational Definitions of Key Terms}

Assessment includes, but is not necessarily limited to, the administration of assessments or placement tests to "determine student competency in computational and language skills and readiness for college" (Lowenthal \& Liu, 2012, p.9). Assessment scores are used to generate course placement recommendations (Michalowski et al., 2011).

Board of Governor's Grant (BOGG) is a fee waiver that is offered by CCC to assist low-income students in paying part of their tuition and fees. Students must be CA residents and meet specified income standards by household size to qualify (Lay, 2010).

Categorical programs are programs that are state and federally funded to provide services to special populations including, students affected by social, economic, language, and educational disadvantages. These programs ensure that students receive more intensive or "high-touch" support than is available to students who do not participate in these programs (California Department Education, 2011; WestEd \& The RP Group, 2012).

Community College Counseling refers to the service of providing assistance and guidance to students in resolving academic, career, vocational, transfer, personal, and crisis intervention in the CCC setting (Academic Senate for California Community Colleges, 2003). 
Deficit thinking posits that the student who fails school does so because of his/her internal deficits, deficiencies in intellectual abilities, linguistic shortcomings, lack of motivation to learn, or immoral behavior (Valencia, 2010).

Educational plan is a written or electronic form that details the step-by-step and semester-by-semester path students need to follow in order to reach their educational goals. The plan and its implementation should be reviewed as necessary to ensure that students' needs and objectives are accurately reflected (Michalowski, Ortiz-Mercado, McDaniel, Chan, \& Sheldon, 2011).

Familismo is a cultural value held by Latinos that involves maintaining close relations and ties to la familia [the family] including extended family such as aunts, uncles, cousins, grandparents, and close friends (Arredondo, Bordes, \& Paniagua, 2008; Paniagua, 2005; Santiago-Rivera, Arrendondo, \& Gallardo-Cooper, 2002).

Extended Opportunity Programs and Services (EOPS) is a state funded program that was established in the CCC system as a result of Senate Bill 164 (SB 164, Alquist) being enacted into law in 1969. The intent of the program is to foster the identification, recruitment, retention, and educational stimulation of students affected by social, economic, language, and educational disadvantages. The EOPS program has two primary goals: (1) to provide "over and above" (additional services than what can be received elsewhere on campus) support services to students with economic, social, and educational challenges, and (2) to increase the number of students who complete their 
educational objectives including, certificate, associate degree, and/or transfer to a fouryear university (Title 5 Regulations, 2011).

First-generation describes a person whose parents did not receive a baccalaureate degree from a four-year university (Davis, 2010).

Hispanic-Serving Institutions (HSI) are public and private two- and four-year colleges and universities with Latino enrollments of $25 \%$ or more full-time students (U.S. Department of Education, 2011).

Mathematics, Engineering, Science Achievement (MESA) is a grant-funded program that was developed in 1970 to increase the number of educationally disadvantaged students transferring to four-year universities to earn math-based degrees. The primary components of MESA include academic excellence workshops, academic support/tutoring, a student study center, career development, and counseling (MESA, 2012).

Matriculation is an agreement between the student and the college for the purpose of realizing the student's educational objectives (California Education Code Section 78212) Matriculation mandates comprehensive services including orientation, assessment and placement, counseling and education planning, and academic interventions to all CCC students (Lowenthal \& Liu, 2012; Michalowski et al., 2011).

Latino refers to both male and female students who self-identify as coming from Latin American descent (Gonzalez \& Gándara, 2005). 
Orientation is designed to provide students with information regarding CCC campus procedures, academic expectations, financial assistance, and any other matters the college or district finds appropriate (Lowenthal \& Liu, 2012; Michalowski et al., 2011).

Persistence describes students' continuous enrollment from one semester to the next while being in good standing (2.00 grade point average or higher) at their institution of higher education (Pascarella \& Terenzini, 2005).

Personalismo is a Latino cultural value of warmth and personal relationships, especially with counselors. A way of demonstrating personalismo and building rapport is through platica [personable small talk] (Arredondo et al., 2008; Paniagua, 2005; Santiago-Rivera et al., 2002).

Puente Project is a privately funded program that was founded in 1981 by Felix Galaviz and Patricia McGrath at Chabot College in Hayward, CA in an effort to increase the number of Mexican-American/Latino students transferring to a four-year university. The Puente program is offered at 59 of the $112 \mathrm{CCC}$ campuses and its model consists of writing, counseling, and mentoring (Puente, 2012; WestEd \& The RP Group, 2012).

Student Success Act of 2012 (SB 1456) was endorsed by Governor Brown and signed into law in September 2012 as a result of the recommendations made by the Student Success Task Force to strengthen student achievement in the CCC system. SB 
1456 is a reform initiative aimed at improving college completion rates for community college students.

The purpose of the SB 1456 is to increase California community college student access and success by providing effective core matriculation services including orientation, assessment and placement, counseling and education planning, and academic interventions. The focus of SB 1456 is on the entering students' transition into college in order to provide a foundation for student achievement and successful completion of students' educational goals, with a priority toward serving students who enroll to earn degrees, career technical certificates, or transfer (Lowenthal \& Liu, 2012, p.1).

TRIO Student Support Services (SSS TRIO) was developed in 1968 and is currently one of eight federally funded programs targeted to serve and assist firstgeneration, low-income, and/or disabled students in reaching their educational objectives. The primary goal of the program is to increase the college retention and graduation of its participants through offering services such as academic tutoring, information and assistance on course selection, financial aid, and scholarships, and counseling services (U.S. Department of Education, 2012).

\section{Statement of Delimitations and Scope of Study}

This study looks at Latino students' perspectives of community college counseling services. Using a qualitative grounded theory research design, the researcher was able to explore the life struggles and counseling experiences of first- 
generation, low-income, Latino community college students as they navigated the system of higher education in an effort to reach their educational objectives.

\section{Significance of the Study}

Latino students tend to face many personal and academic challenges that make them less likely than other demographic groups to reach college completion. Latinos are likely to: (a) come from a poor socioeconomic background, (b) be first-generation students, (c) have poor college preparatory experiences, and (d) face challenges that interfere with their academic achievement (Davis, 2010; Gándara, 2010; Pulliams, 1990). As the Latino student population continues to increase within the CCC system, the state of CA, and the United States, reducing the gap in their completion rates is a critical social justice and equity issue. Projections in the state of CA suggest that by 2018, 22 million new college degrees will be needed in the labor force (Lay, 2010). Unfortunately, based on the current completion rates, CA is expected to fall short by at least 3 million degrees (associate or higher) (Lay, 2010). This shortfall in degrees will create barriers to equal participation in the labor force and inequitable economic opportunities for Latino students, decreased civic participation, and lower tax revenues, thus portending grave consequences for the economy and the social structure of the United States (Gándara, 1995; Lay, 2010; Museus \& Ravello, 2010; Woodlief \& Olson, 2002). Ultimately, this underachievement of Latinos presents a problem for both the state of CA and the CCC system (Kimura-Walsh et al., 2008). Given the increasing number of Latino students attending CCC and their risk of attrition (Vela-Gude et al., 
2009), understanding all avenues of reform outcomes, especially those delivered by counseling services, will be necessary to support Latino students to reach completion in CCC.

\section{Conclusion}

Employing a qualitative grounded theory research design, this study seeks to learn how first-generation, low-income, Latino students perceive, negotiate, and develop a relationship with their community college counselor. This dissertation is organized into four remaining chapters. Chapter Two reviews the literature pertaining to the role of familismo [close relations and ties to the family] and parental support in promoting students' pursuit for college, the role and function of community college counselors, Latino students' high school counseling experiences, community college counseling services, and the importance of the student-counselor relationship. Chapter Three delineates the qualitative grounded theory research methods of this study. Chapter Four describes the qualitative findings of this study. Chapter Five concludes with an interpretation of the findings, a discussion of the limitations and implications of the study, recommendations for action and further study, and reflections on the research process. 


\section{Chapter Two: Literature Review}

\section{Introduction}

The purpose of this study was to explore how first-generation, low-income, Latino students perceived, negotiated, and developed a relationship with their community college counselor. This chapter is divided into three sections including the scope of review, structure of review, and literature review. The literature review specifically focuses on the role of familismo [close relations and ties to the family] and parental support in promoting students' pursuit for college, the role and function of community college counselors, Latino students' high school counseling experiences, community college counseling services, and the importance of the student-counselor relationship.

\section{Scope of Review}

In this review, Latino students' perspectives of community college counseling services were examined by focusing on one primary research question: How do firstgeneration, low-income, Latino community college students perceive, negotiate and develop a relationship with their community college counselor? The ERIC (EBSCO), Google Scholar, and ProQuest education electronic databases were searched for peerreviewed articles. The following research terms were used to guide the electronic search: (a) counseling, (b) advising, (c) guidance, (d) community college, (e) higher education, (f) student-counselor interactions, (g) relationships, (h) Latino/Hispanic/Mexican, and (i) support programs. Abstracts were read to gather 
research articles relative to the initial research question. The references of the articles chosen from the initial screening were reviewed to obtain additional articles from authors who were cited repeatedly within the literature. To create a record of publication, information was gathered from each article including the general topic, research questions, participants, location, methodology, findings, and areas for further research. The topics that emerged from the literature reviewed included: (a) negative high school counseling experiences of Latino students, (b) community college counseling experiences of students of color, (c) family support, (d) counseling in categorical support programs, (e) and faculty-student interactions. The studies were then grouped by topic and education context (high school and community college).

\section{Structure of Review}

The literature review examined Latino students' experiences and perspectives of high school and community college counseling services. The crucial information for this review is organized into seven sections. First, a summary will be provided relative to the research about familismo [close relations and ties to the family] and parental support that promotes students' pursuit for college. Second, community college counseling and its core functions will be defined. Third, the role of community college counselors in the matriculation process will be described. Fourth, the role of community college counselors in student support and advocacy will be presented. Fifth, a review of high school counseling services will be summarized. Sixth, literature on community college counseling services will be discussed. Seventh, the importance of 
the student-counselor relationship will be explained. Finally, a summary of the findings and areas for further research will be provided.

\section{Literature Review}

\section{Familismo and parental support promote students' pursuit for college.}

Familismo [close relations and ties to the family] among Latinos is paramount (Arredondo et al., 2008; Paniagua, 2005; Santiago-Rivera et al.,2002). "Familismo encompasses loyalty, commitment, and dedication to la familia [the family]" (Ojeda, Navarro, \& Morales, 2011, p.223). In fact, because Latinos value interdependence, unity, and collaboration among their family, they generally turn to their familia [family] during times of stress and economic difficulties (Arredondo et al., 2008; Paniagua, 2005; Santiago-Rivera et al., 2002). Although family ties often extend to relatives such as aunts, uncles, cousins, grandparents, and close friends, Latinos hold the highest value for their parents (Santiago-Rivera et al., 2002). Nevertheless, Latinos often come from families with a limited educational background.

Latinos are more likely than any other ethnic group to be first-generation (neither parent has obtained a baccalaureate degree from a four-year university) and come from homes where English proficiency and parental education is low (Davis, 2010; Gándara, 2010). In fact, Gándara (2010) indicated that 41\% of Latina mothers have less than a high school diploma compared to $6 \%$ of Caucasian, $16 \%$ of Asian, and $18 \%$ of African-American mothers. She further claimed that an even smaller number of Latina mothers hold a baccalaureate degree or higher (10\%), compared to $32 \%$ of 
Caucasian, $45 \%$ of Asian, and 15\% of African-American mothers. Such findings often fuel cultural deficit views which posit that parents and communities of color (a) do not value the importance of an education, (b) fail to instill such values in their children, and (c) are at fault for poor student academic performance (Valencia, 2010). Contrary to deficit views, current research has portrayed Latino parents as a central source of support, encouragement, and motivation for Latino students (Ceballo, 2004; Ceja, 2004; Delgado-Gaitán, 1990, 2004; Gándara, 1995).

Convinced that anything is possible for their children, Latino parents socialize their children to believe that there is no other option but to attend college (Ceballo, 2004) and will do whatever it takes to help them succeed (Zell, 2010). In a qualitative study, Ceja (2004) interviewed 20 Latina high school students to examine the ways in which direct and indirect parental messages influenced their college aspirations. Although this study focused on female students, the researcher confirmed that Latino parents influenced their daughters directly by stressing the importance of doing well in school and attending college as a way to enhance economic and occupational mobility. Parents also influenced their children indirectly by using their lived experiences and marginal conditions as stories of empowerment and motivation (Ceja, 2004). These findings suggest that although the messages transmitted by parents to their children did not explicitly mention the importance of attending a particular type of higher education institution, the messages of encouragement and support were important in making students realize that they wanted to achieve and pursue higher education. 
Similarly, Ceballo (2004) interviewed 10 Latino students attending Yale University to investigate the role of parents and home characteristics in their academic success. Providing extensive examples of student responses, the researcher reported that all of the students believed that their parents maintained unconditional commitment to education and viewed it as the best and only route to escape poverty. Students in this study mentioned that their parents were minimally involved in their education due to language barriers and limited schooling, but that they expressed their support through unspoken behavior. For example, parents would lower the television volume if their children were studying, they would stay up to keep them company through late night projects, and would not require them to work or do chores so that they could focus solely on their education. However, the major limitation of this study was that participant interviews were conducted in 1986 with the views of a particular generation of Latino students. More research is needed about the views of students in the current generation. Nevertheless, these findings suggest that although Latino parents are constrained by their limited educational background, their parenting practices and nonverbal expressions conveyed the importance of education and their high support for students' educational attainment.

Moreover, Gándara (1995) individually interviewed 50 low-income Latino men and women who had completed doctoral level education (PHD, MD, or JD) to investigate their educational mobility having come from low-income homes with little education. Using a large sample, the researcher found that parental involvement, 
especially from the mother, was a critical component in the academic success of participants. Most participants in this study reported that their parents counseled, encouraged, inspired, and supported them in reaching their educational goals and objectives. Some participants recalled instances of their parents assisting them with school work to the extent they could, which was typically very limited. They further mentioned that although their parents did not have the resources or the experience to provide thorough assistance with school work, they protected their time for study, provided financial assistance, modeled and encouraged literacy, and instilled in them high standards.

Furthermore, in an ethnographic study, Delgado-Gaitán (1990) studied 20 Latino families to investigate how Spanish-speaking parents assisted their children in the educational process and how they socialized them to reach their potential. The researcher found that though the lack of communication between school and home caused many Spanish-speaking parents to feel isolated and ignorant about their role in their children's schooling, parents' value for schooling was not eliminated. The researcher revealed that parents demonstrated their value for education by providing their children with a nurturing learning environment at home filled with conversation about family events, discussion of daily routines, reading of favorite books, and completion of puzzles. The researcher further indicated that although parents took pride in assisting their children with the organization of homework settings, their limited educational experience often hindered them from providing extensive support with the 
completion of homework assignments. These findings revealed that Spanish-speaking Latino parents strongly value education for their children and that their participation in their children's schooling takes many forms in the home and in the school depending on factors such as parents' knowledge of the school, their ability to communicate, and the school's receptivity in involving parents.

In general, the combination of familismo and parental encouragement has been found to be a (a) motivating factor in Latino students' pursuit of higher education, (b) positive predictor in students' determination to complete their college education, and (c) source of support to students' college persistence (Ojeda et al., 2011). Latino parents may not have had any schooling in the U.S., or may have limited knowledge about the educational system and the proper resources to effectively support their children's schooling, yet they value education highly and provide a strong emotional environment in the home (Delgado-Gaitán, 2004; Gándara, 1995, Ojeda et al., 2011). Home activities between Latino parents and their children demonstrated that parents inspired their children, taught them language and literacy, and helped them adjust to a different culture (Delgado-Gaitán, 1990, 2004). Parents motivated and encouraged their children to stay in school through story-telling of their own life experience of resilience, courage, value for education, and expectation for their success (Delgado-Gaitán, 2004).

Nevertheless, parents' desires for their children to pursue a college education are not sufficient (Cabrera \& Padilla, 2004; Delgado-Gaitán, 2004). Due to their own academic shortcomings, language, and cultural barriers, Latino parents are seldom in 
the position to provide thorough information about academic planning and college requirements (Corwin et al., 2004; Delgado-Gaitán, 1990; Gándara, 1995; Zalaquett, 2005). Latino parents' low levels of education also limits their ability to offer specific advice to support their children's educational interests (Kimura-Walsh et al., 2008; Zalaquett, 2006; Ojeda et al., 2011). Consequently, institutional agents such as counselors can close the gap in knowledge and provide support for Latino students to navigate the college system and reach their educational goals.

Defining community college counseling and its core functions. In the last 30 years, researchers have recognized the importance and the need for counselors to assist students in reaching their educational goals (Board of Governors, 1992; Croquett, 1978; Pulliams, 1990; Vasconcellos, 1988; Wiseman \& Messitt, 2010). The American Counseling Association (ACA) (2010a) defined counseling as "a professional relationship that empowers diverse individuals, families, and groups to accomplish mental health, wellness, education, and career goals." Similarly, the Academic Senate for California Community Colleges (ASCCC) (2003) defined counseling as "the act of providing assistance and guidance to students in resolving academic, career, vocational, transfer, and personal problems and difficulties in the community college setting." While there is no statewide definition for community college counseling, ACA (2010a), ASCCC (2003), and California Education Code (AB1725), have affirmed the relationship of counseling faculty to the mission of the CCC system and to the success of students. The landmark community college legislation, AB1725 stated: 
Open access to community colleges must be assured for all adults who can benefit from instruction. Such access is meaningful only if supported by a system of assessment, counseling, and placement that assists students in identifying their talents and abilities, directs them to courses that meet their needs, and maintains standards designed to ensure their success (Vasconcellos, 1988, p.1).

Likewise, the Board of Governors in its Basic Agenda (1992) demonstrated support for student success and recognized the need for community college counseling in helping students succeed, thus approving the Title 5 regulations that required that all CCC offer counseling services for their students. Title 5 Regulations articulated that counseling programs in CCC shall include, but not be limited to three core functions including:

(1) Academic counseling, in which the student is assisted in assessing, planning, and implementing his or her immediate and long-range academic goals, (2) Career counseling, in which the student is assisted in assessing his/her aptitudes, abilities, and interests, and is advised concerning current future employment trends, and (3) Personal counseling, in which the student is assisted with personal, family, or other social concerns, when that assistance is related to the student's education (Section 51018).

Using Title 5 regulations and the ethical code of ACA, in 1997 the ASCCC adopted a set of universal standards of practice for all CCC counseling programs 
(ASCCC, 1997). The counseling functions delineated by ASCCC (1997) included the three core functions articulated by Title 5 regulations (Academic Counseling, Career Counseling, and Personal Counseling), but incorporated six additional core functions including:

(1) Crisis intervention, either directly or through cooperative arrangements with other resources on campus or in the community, (2) Multicultural counseling, in which students are counseled with a respect for their origins and cultural values, (3) Outreach to students and community to encourage them to avail themselves from services, focused on maximizing all students' potential to benefit from the academic experience, (4) Consultation to the college governance process and liaison to the college community to make the environment as beneficial to the intellectual, emotional, and physical development of students as possible, (5) Research and review of counseling programs and services with the goal of improving their effectiveness, and (6)Training and professional development for counseling and staff, interns, and others in the college community (p.2). Together, the nine standards and practices for $\mathrm{CCC}$ counseling programs provide a framework for the design, development, delivery, and review of counseling department policies and practices (ASCCC, 1997). By providing guidance and intervention through an integrated combination of support services and counseling functions, counselors play a critical role in carrying out the multiple missions of the 
CCC system, assisting students in reaching their objectives, and offering support through the matriculation process.

\section{The role of community college counselors in the matriculation process.}

CCC counselors are critical to the delivery of the matriculation focused support services within the Student Success Act of 2012 (SB 1456). Matriculation support services include but are not necessarily limited to:

(a) Orientation, designed to provide students with information concerning campus procedures, academic expectations, financial assistance and any other matters the district finds appropriate; (b) Assessment upon enrollment to determine student competency in computational and language skills and readiness for college; (c) Counseling and education planning; (d) Referral to specialized support services as needed (e.g., financial aid, health services, career services, veteran support services, foster youth services, extended opportunity programs); and (e) Evaluation of each students' progress, and required advisement and counseling for students who are enrolled in basic skills courses, who have not declared an educational goal, or who are on academic probation. (Lowenthal \& Liu, 2012, p.8)

The matriculation process is intended to ensure that all students have access to higher education opportunities and to provide students with the steps they need to take to achieve their educational goals (Michalowski et al., 2011). Community College counselors play a significant role in all components of the matriculation process. 
The role of community college counselors is further outlined by the Consultation Council Task Force on Counseling (ASC, 2003). The Consultation Council Task Force on Counseling explained that through orientation, community college counselors provide new students with the opportunity to become familiar with the college campus, its programs and services, degree options, and policies and expectations. In addition, they indicated that using multiple measures of assessment, counselors: (a) holistically evaluate students' skills, abilities, strengths, and areas of needed improvement, (b) accurately place students into courses, and (c) develop student educational plans (a written or electronic form that details the step-by-step and semester by semester path students need to follow in order to reach their educational goals) that meets students' needs. The Consultation Council further explained that through student follow-up, counselors provide student interventions and referrals to other campus services (e.g., tutoring, financial aid, childcare, etc.) or other community services that may assist students in overcoming any challenges or obstacles that may hinder their ability to reach their educational goals.

The Academic Senate for California Community Colleges (ASCCC) (2012) revised and adopted their position regarding the essential functions of counselors and the delivery of counseling services by adding a discussion about the importance of educational plans and briefly covering the use of technology in the delivery of counseling services. According to the ASCCC (2012), student education plans 
developed by CCC counseling faculty should include but not be limited to the following:

(a) Consideration of and planning for multiple layers of student goals (associate degree or higher), (b) recommended course sequencing that reflects a balanced course load based on a students' strengths, scheduling patterns, and course requirements with prerequisites built in, (c) student support referrals to services both on and off campus, (d) information about auxiliary requirements to meet a student's educational goals (testing, Advanced Placement (AP) scores, minimum GPA, and deadlines), (e) planning for and prioritizing multiple transfer institutions, (f) recommendations of courses to increase a student's competitiveness for admission, if transfer is intended, (g) distinction of catalog rights and options for selecting a catalog year, (h) professional knowledge of programs and differences between programs at different institutions, and (i) evaluation of transcripts from other institutions (p.4).

Through educational planning, counselors take into account students' stated goals within the context of students' personal lives and the changes that may take place as they progress through the system of higher education (ASCCC, 2012). ASCCC (2012) indicated that due to the diverse abilities of the CCC student population, some students may be self-directed and guide themselves toward the achievement of their goals through accessing technology and college resources (e.g., college catalog, advisement sheets). However, the ASCCC (2012) further claimed the majority of 
students, even those who appeared to be self-directed, benefited from counseling services as many of them utilized counseling to have their decisions and pathways affirmed.

Overall, community college counseling is fundamental to the delivery of matriculation services (ASCCC, 2003). Through providing an essential integrated combination of orientation, assessment, educational planning, student follow-up, referral, and multiple forms of counseling services (academic, career, personal, vocational, multicultural, and crisis intervention), community college counselors assist students in navigating the system of higher education and are critical in ensuring that students persist and retain toward the achievement of their educational objectives (ASCCC, 1995, 1997, 2003, 2012).

The role of community college counselors in support and advocacy. Aside from playing a critical role in the matriculation process, community college counselors also perform various support and advocacy roles that contribute to student success. In his seminal theoretical piece, Croquett (1978) noted counseling as a cornerstone of student retention that when provided effectively will contribute to the development of more mature student academic and career goals, a more positive attitude, and increased student academic performance. Three decades later, Wiseman and Messitt (2010) similarly reported that counselors contribute to student success and retention by empowering students to utilize their prior knowledge and think critically about their academic plans and decisions before coming to final conclusions. To illustrate, 
Pulliams (1990) conceptually noted that effective community college counselors possess a strong sense of professional mission and a personal drive to help students reach their fullest potential. He further theorized that having rapport with students, the ability to understand their experiences, and the ability to develop favorable relationships with students were important strengths counselors should possess in order to be able to meet the academic and personal needs of the diverse community college population.

Under Pulliams' (1990) description of effective community college counseling, counselors perform multiple roles of learning agents, advocates, and student developers to meet students' needs. Pulliams (1990) indicated that as learning agents, counselors assist students in setting realistic goals and in understanding the need and the value of completing their academic objectives. Moreover, he stated that as student advocates, counselors offer advice, assist students in accessing services and resources related to student success, and empower them to face and overcome obstacles. Counselors support students with developmental needs, stress the importance of skill-building, and empower them to build a pattern of success (Pulliams, 1990). Nevertheless, the limited empirical research conducted to date is insufficient for substantiating Pulliams' (1990) conceptual framework.

The literature related to the function, role, and support of community college counseling services (ACA, 2010b; ASCCC, 1995, 1997, 2003; Croquett, 1978; California Education Code, Title 5 regulations; Pulliams 1990; Wiseman \& Messitt, 2010), revealed that although there is no statewide definition or limitations on the role 
of community college counselors, the multiple core functions of counseling substantiate the critical support for students and facilitate the multiple missions of the CCC system. Through the delivery of matriculation activities and by performing support and advocacy roles, community college counselors provide encouragement, assistance, guidance, and referral to on-campus and community resources that are essential for student persistence and completion (Pascarella \& Terenzini, 2005; Tinto, 2000). Although the combination of findings indicated the obligation of community colleges to provide counseling services, there is minimal empirical evidence that counseling is adequately provided to meet the diverse needs of CCC students. Empirical evidence is even more limited in the area of community college counseling for Latino students who represent the fastest-growing student population. Therefore, reviewing high school literature is important in providing some grounding in what is known to date related to Latino students' perspectives and experiences with counseling services.

High school counseling services. Research conducted in the high school setting indicated that Latino students have preferred counselor characteristics that they feel are important for academic success. Eckenrod-Green and Culbreth (2008) interviewed eight Latino high school students to explore their perceptions about their school counselor. Although the researchers used a small sample, students made a convincing claim that they preferred counselors who possessed Spanish-speaking abilities, who listened and who were understanding, patient, trustworthy, friendly, and helpful. While it is reasonable to expect that these characteristics are portrayed by 
counselors and that high quality counseling services are available to all students as a baseline resource for academic planning, detrimental differences continue to exist in high school counseling services (Corwin et al., 2004). Researchers found that minority and female students are more likely to seek counseling services (Bryan et al., 2009), yet many educators still have the misconception that Latino students are not interested in education and/or are not capable of succeeding in school (Zalaquett, 2005). In fact, Latino students are still singled out as not having aspirations and/or abilities to conquer the rigors of college (Martinez, 2003). Based on high school counselors' thoughts of students having unrealistic aspirations, many are steered away from pursuing a fouryear college education and guided toward shorter certificate programs (Grubb, 2001, 2006; Martinez, 2003). In fact, the high school counseling literature suggested that counselors (a) reveal differential advising, (b) misinform students, and (c) rush through the counseling process.

Counselors reveal differential advising. The literature suggested that many counselors often used differential treatment and advised students based on their own perceptions of students' abilities. Immerwahr (2003) qualitatively analyzed the challenges facing Latino high school students who encountered obstacles to higher education. The author conducted focus groups with 50 Latino students and interviews with four parents and 14 teachers in predominantly Latino high schools in several states. Findings indicated that Latino students encountered various barriers to achievement (minimal adult supervision, misinformation about college requirements, and a choice of 
less successful options by students). More specifically, the researcher indicated disparities between the counseling experiences of "college-prep" students (typically coming from middle-class families), "non-college-bound" students (often coming from working class families) and "college-maybes" (often coming from immigrant families where parents did not complete college). The researcher discovered that counselors expected "college-prep" students to attend college, typically assisted them with the application process, provided them with resources, and guided them every step of the way. On the other hand, "non-college-bound" students, who often experienced academic struggles, were perceived by counselors as "non-college material" and were provided with minimal direction on the process for college entrance. Similarly, the "college-maybe" students received minimal guidance from their counselors and were often forced to make all of the decisions related to their educational futures on their own. Students in this study claimed that the lack of guidance they received from their counselor combined with their parents' limited knowledge about high school and college requirements led them to base their information about college on what they heard from other students, siblings, cousins, or close family friends. The results of this study indicated that due to receiving minimal guidance from parents and inadequate or misleading information from counselors, Latino students were poorly informed about their options for the future and were at risk of making pivotal and life-changing decisions without sufficient knowledge. 
Similarly, using a mixed methods approach, Kimura-Walsh et al. (2008) surveyed and conducted focus groups with 16 Latina students attending an urban majority Latino high school. The authors assessed students' perceptions regarding social expectations to attend college, availability of resources, sources of social support, and barriers to higher education. Although this study did not focus on the experiences of male high school students, the extensive use of student experiences informed the researchers' findings that counselors often advised students according to their college eligibility and class ranking. In doing so, counselors unequally distributed college resources to the students they served resulting in differential opportunities for Latina students. For example, students in this study indicated that counselors often denied them college applications based on their high school academic ranking. The researchers further indicated that institutional practices often channeled college preparatory resources and assistance to the top 10 percent of the graduating class at the cost of those who were non-high achievers. They claimed that students who possessed a 3.0 grade point average (GPA) were considered University of California (UC) bound and had access to resources to help them complete their college applications. Their counterparts, students who possessed a lower grade point average, were: (1) tracked into the California State University (CSU) system or into the community college system, (2) only provided with access to resources for their designated institution types and, (3) prevented from obtaining information about more selective schools. 
Using a case study approach, Martinez (2003) qualitatively examined the schooling experiences of four first-generation Latino students who were subjected to low expectations and denied access to opportunities available to the mainstream students in high school. Although the researcher used a small sample, the use of student stories informed the researcher's findings that participants repeatedly experienced inequity through low expectations from their counselors. Students in this study indicated that their counselors discouraged them from applying to four-year universities and advised them that applying for scholarships was a "waste of time." They further claimed that the lack of guidance and the low expectations they received from their counselor made them feel unprepared for college and doubtful about their decisions to pursue college.

Research indicated that counselors often express more concern for students who come from prestigious or wealthy families and provided them with additional services (Vela-Gude et al., 2009). On the other hand, counselors underestimated the academic potential of less fortunate students and often discouraged them from taking advanced placement courses and college entrance exams, and applying to Ivy League universities (Vela-Gude et al., 2009). The results of these studies (Immerwahr, 2003; KimuraWalsh et al., 2008; Martinez, 2003) indicated that prioritizing services based on lowexpectations, class rank, and GPA can result in an inequitable distribution of resources, time, and attention for students with the least resources who typically need the most 
counseling support. Being misinformed about the college process can have a similar negative effect on the academic preparation and success of Latino high school students.

Counselors misinform students. The literature suggested that Latino students are often misinformed by their counselors. In a qualitative study, Zalaquett (2005) retrospectively interviewed 12 first-generation Latino students enrolled in an urban university about their high school experiences to detect Immerwahr's (2003) barriers to achievement (minimal adult supervision, misinformation about college requirements, and a choice of less successful options by students). Providing student experiences as evidence, the researcher found counselors provided students with minimal guidance about higher education and showed little interest in students' futures. Zalaquett (2005) indicated that being misinformed about scholarships, financial aid, and college entrance requirements caused many Latino students to make poor choices about their postsecondary education. Some students in this study reported that they did not gain admission to a higher education institution the first time they applied due to being misinformed about the required paperwork, deadlines, and the overall admission and registration process. The results of this study indicate that Latino students who are firstgeneration are frequently left to make all decisions about their future on their own because of the minimal guidance available to them from their counselors. However, a major limitation to this study is that due to the retrospective nature of students' responses, the results may be tainted by student memory. 
Likewise, in a three-year qualitative study of 12 college preparation programs in northern and southern California high schools, Corwin et al. (2004) conducted focus groups and interviews with teachers, counselors, assistant principals, principals, students, and parents to analyze how disparities in counseling services affected college access for students of color. Drawing on student perspectives, the researchers found that students expressed overwhelming frustration over their counseling interactions and felt that counselors often served as impediments to college access. Students in this study complained about being incorrectly assigned to take courses that did not fulfill college eligibility requirements. They claimed that due to counselors' unwillingness to change their class schedule, they often had to make up courses at a local community college to fulfill the required coursework to meet college entrance requirements. Overall, the researchers indicated that most students believed that counselors did not encourage them to attend college after high school and often felt that counselors' main role was to assist with class scheduling to meet high school graduation requirements. Though the researchers did not indicate the number of student participants who were interviewed, this study demonstrated that students' negative perceptions of their high school counselors tarnished their confidence in counselors' ability to accurately support them in pursuing their college aspirations for the future.

Vela-Gude et al. (2009) interviewed eight Latino undergraduate students attending a Hispanic Serving Institution (HSI) to analyze their perceptions about their high school counseling experiences. Though the researchers used a small sample, the 
extensive use of student stories informed the researchers' findings that students were often sent to higher education with insufficient or inadequate advisement. Participants in this study recalled experiences of losing credit for taking concurrent enrollment courses (courses taken at a community college while enrolled in high school) and receiving minimal information regarding the college application process, scholarships and other resources available to them. They further indicated that their counselors were uninterested in providing mentoring and individual attention to students who came from less than prestigious circumstances, often underestimated their potential to succeed academically, and were inaccessible. A limitation to this study, however, is that due to the retrospective nature of students' responses, the results may be tainted by student memory.

Counselors rush through the counseling process. The literature indicated that many students feel that they are rushed through the counseling process and are often left feeling that their counselor simply considers them a number (Eckenrod-Green \& Culbreth, 2008). In fact, after interviewing eight Latino high school students to explore their perceptions of their counselor, Eckenrod-Green and Culbreth (2008) found that counselors were often rushed and therefore unsupportive and not genuinely interested in assisting students with their individual needs and concerns. Students in this study experienced a lack of genuine care, trust, support, and confidence in counselors, and yet a great desire to build trusting relationships. 
Disparities existed between the intended effects of counseling services and students' perceptions of the usefulness of these services at their schools. In a three-year qualitative study of 12 college preparation programs in northern and southern California high schools, Corwin et al. (2004) conducted focus groups and interviews with teachers, counselors, assistant principals, principals, students, and parents to analyze how disparities in counseling services affected college access for students of color. The researchers found that students overwhelmingly expressed frustration over their counseling interactions stating that they needed more time to receive adequate attention from their counselors. Students in this study further claimed that making an appointment to see their counselor often took weeks, too long to change their schedule and still have the ability to catch up in a new class. Overall, students lacked confidence in their counselors and felt a general distrust of counseling services.

Counselors in this study, however, expressed school constraints such as having numerous counseling duties (i.e., scheduling issues, classroom referrals), limited resources (including size of personnel), and inadequate time to effectively counsel students due to high student-to-counselor ratios. An academic counselor in this study explained that due to his large caseload, he only saw $9^{\text {th }}$ through $11^{\text {th }}$ grade students four times per year for ten minutes during each session. He confirmed that he spent additional time with $12^{\text {th }}$ grade students because a major part of his responsibilities included monitoring graduation requirements. The results of this study revealed that although both counselors and students pointed to similar challenges of fostering helpful 
relationships, the negative perceptions the students had of their counselors stood out. Therefore, addressing inequities in quality and accessibility of counseling is vital to enhance students' chances for educational and career advancement.

Dominated by qualitative methodological designs and small samples, the limited high school counseling literature discussed thus far (Aviles et al., 1999; Bryan et al., 2009; Corwin et al., 2004; Eckenrod-Green, 2008; Immerwahr, 2003; Kimura-Walsh et al., 2008; Martinez, 2003; Vela-Gude et al., 2009; Zalaquett, 2005) revealed reoccurring themes that counselors (a) misinformed students about college eligibility requirements and opportunities available to them, (b) incorrectly assigned students to courses, (c) used differential treatment and advisement based on their assumptions regarding Latino students and their academic potential, (d) rushed students through the counseling process due to high counselor-student ratios, and (e) demonstrated a lack of genuine care for students. Such experiences have been found to make students develop selfdoubt in their ability to succeed academically, feel marginalized, and undeserving of a place in college (Terenzini et al., 1994; Zell, 2010). Although the results of these studies confirmed Latino students' preferred counselor characteristics, negative counseling experiences, and initial suggestions for change, they generally focused on the high school counseling experiences of Latino students. Thus, there is a gap in the literature about the counseling experiences, perceptions, and needs of Latino community college students. 
Community college counseling services. Latino students arrive to CCC campuses inspired to pursue higher education, to gain independence (Cabrera \& Padilla, 2004), and with the desire to be role models who can make meaningful contributions to their family, community, and society (Terenzini et al., 1994; Zell, 2010). Although the CCC system has recognized that community college counseling services are essential to assist students in meeting their goals, students indicate that the counseling services they receive are not meeting their needs (Bryan et al., 2009; Corwin et al., 2004; EckenrodGreen, 2008; Immerwahr, 2003; Kimura-Walsh et al., 2008; Martinez, 2003; Vela-Gude et al., 2009). The limited community college counseling literature revealed that there are differences in the use of counseling among community college students, and that many Latino community college students face inaccessibility to counselors and inadequate advisement as they did in high school. On the other hand, research evidence indicated that students who are part of categorical support programs (state funded programs to serve special populations) have a different and more positive experience with their community college counselor.

Differences in the use of counseling. Research indicated that the utilization of counseling services within CCC varies based on students' race and individual needs. Orozco et al. (2010) interviewed 363 Latino, African American, Asian, Native American, and Caucasian immigrant community college students to examine students' utilization and perceptions of counseling. The study revealed that Caucasian and Asian students were more likely to seek counseling services than Latino and Native American 
students. Compared to Caucasian (70\%) and Asian (65\%) students, only 50\% of Latino students saw a community college counselor (Orozco et al., 2010). The researchers suggested that this difference in the use of counseling was possibly due to the fact that the majority $(60 \%)$ of all community college students are the first in their family to attend college and may be unfamiliar with services available to them. It may also be due to their poor experiences with counselors in their previous years of schooling (Orozco et al., 2010; Woodlief \& Olson, 2002). Though the researchers gathered a large sample of students, the small number of Latino students in that study $(28 \%$ of the sample) specifically provided a narrow view on the reasons why this group of students may be less likely to seek counseling services.

Similarly, in a national qualitative study conducted in 15 different colleges Grubb (2006) interviewed counselors, directors of counseling, and directors of student services to examine the special needs of community college students, the basic structure of counseling, and counselors' interactions with students. Using student perspectives as evidence, the researcher indicated that students who were first-generation, unmotivated, and indecisive about their educational goals were less likely than honors students, international students, and motivated students to seek and receive counseling services. Counseling personnel in this study suggested that students who had clear goals often sought counseling services to verify the completeness of their courses, while students who were undecided on their goals did not seek counseling because of limited resources or fear of not knowing what to ask. They explained that counseling was most helpful to 
"students in the middle" those who had some idea about their goals and some initiative to seek counseling. Although the researcher provided evidence about students' utilization of community college counseling, this study had two major limitations. First, the researcher did not state the race of students who typically sought counseling services. Second, the study was limited to the voices and views of counseling faculty and counseling administrators, thus providing a limited view about students' perspectives and reasons behind not seeking community college counseling services.

Inaccessibility to counselors and inadequate advisement. Latino students believed that community colleges provide them with the opportunity to improve their skills, develop their goals, and prepare them to meet their future educational endeavors. However, counseling services have not been found to be congruent to students' needs (CCCSE, 2012; Nodine, Jaeger, Venezia, \& Bracco, 2012; Zell, 2010). The Center for Community College Student Engagement (CCCSE) (2012) indicated that although 91\% of community college students reported that counseling was a somewhat or very important service, many students were not getting the type of counseling they needed to help them reach their academic goals. In fact, $71 \%$ of students agreed or strongly agreed that counselors helped them identify the courses they needed to take during their first semester, but only $38 \%$ agreed or strongly agreed that counselors helped them create a plan to meet their academic goals.

Similarly, after conducting focus groups with 161 current and former community college students in four states (Florida, North Carolina, Ohio, and Texas), 
Nodine et al. (2012) found that counseling was perceived as a critical component in students' college experience. Nevertheless, the researchers indicated that students' counseling experiences affected their perceptions about the effectiveness of counseling services and the quality of their college experience in general. In fact, the researchers found that having positive counseling experiences helped students stay connected, on track, and in college, while negative counseling experiences contributed to students feeling disconnected, being off track, and likely to drop out. In general, students in this study indicated a desire to be more connected to and supported by community college counselors.

\section{High counselor-to-student ratios also present a major barrier for students.} According to the California Association of School Counselors (CASC, 2010), the maximum recommended counselor-to-student ratio is 250:1. Nevertheless, the American Counseling Association (ACA) (2010b) indicated that most educational institutions have not been able to keep the recommended ratio. They claimed that the average counselor-to-student ratio in United States K-12 schools is 467:1. This ratio is higher in the state of California (809:1) and even higher in Santa Clara County (1010:1) (CASC, 2010). More specifically, the CCC system has also struggled to meet the recommended counselor-to-student ratio (370:1) cited by the ASCCC (2003). After surveying 67 community college counselors at 54 community colleges from 28 states about common counseling practices, the American College Counseling Association's Community College Task Force (ACCACCTF) (2010) determined an average 
counselor-to-student ratio of 2000-2500:1. This ratio is more than double the counselor-to-student ratio at ETCCD (913:1; calculated in terms of the five full-time, six part-time general counselors, and the total headcount of 7,303 indicated by the CCCCO for the Spring 2012 term). The high counselor-to-student ratios in educational institutions often lead students to face: (a) long waits, (b) difficulty making appointments, (c) pressured time limits with their counselors, and (d) rushed conversations (Nodine et al., 2012; Public Agenda \& WestEd, 2012; Venezia et al., 2010; Woodlief \& Olson, 2002). Due to students' limited time with their counselor, their educational plan (a written or electronic form that details the step-by-step and semester-by-semester path that students need to follow in order to reach their educational goals) is cut short leaving students without knowing which courses they need to take next to meet their goals (Orozco et al., 2010; Nodine et al., 2012; Venezia et al., 2010).

Constrained access to counselors and limited time for counseling sessions often results in inadequate advisement (Nodine et al., 2012; Orozco et al., 2010; Public Agenda \& WestEd, 2012). Zell (2010) interviewed 15 Latino current and former community college students to examine the impact of their psychological and subjective experiences in college on their persistence toward achieving their educational goals. The researcher found that common problems identified by students included counselors' lack of knowledge or unfamiliarity with students' interests and ill advisement regarding graduation and transfer course requirements. Students in this study indicated that 
counselors rarely explained which courses were needed to meet degree and/or transfer requirements, causing them to lose credits needed to meet the requirements of their particular four-year institution. Overall, the combination of inadequate advisement and negative personal interactions with community college counselors presented a "make or break" experience for Latino students (Zell, 2010, p. 179). Although student experiences provided convincing evidence of counselors' inadequate advisement, this study was based on self-reported data. Thus, the results could have been affected by students' ability to remember their experiences.

Similarly, in their qualitative study, Orozco et al. (2010) interviewed 363 students of color across nine different CCC campuses to explore how they perceived and utilized academic advising and personal counseling. Using student stories as evidence, the researchers also found inadequate advisement. Due to inappropriate and lack of timely information, students in this study reported finding themselves unfairly placed into remedial courses and taking courses that were not necessary to meet their goals, which was a waste of their time. One Latina student in this study indicated that in high school she was in the top 10 percent of her graduating class, yet when she arrived to the college campus, she was placed in two transferable courses and three that were not transferable. She explained that her counselor wanted to ease her into college, but that this placement caused her to have to make up the remaining transferable courses during the summer term. This particular study did not primarily focus on Latino students' perceptions. 
Moreover, in a mixed methods study, Venezia et al. (2010) conducted focus groups with 257 students of unidentified ethnicities, interviews with 12 counselors, and telephone surveys with an unidentified number of matriculation officers to examine the policies and practices of assessment and placement in CCC and to hear students' perspectives about their assessment and placement experiences. Using extensive student voice as evidence, the researchers found that although community college counselors play a significant role in matriculation services, most students in this study believed that matriculation services were a "one-shot-deal" (something that happens over the course of one day and is never revisited) (p.2). When describing their experiences with community college counseling services, students in this study reported frustration over long waiting lines, limited attention, and low expectations regarding course placement. Students further indicated that inaccessibility to counseling limited their ability to (a) discuss and clarify assessment and course placement (b) follow-up with their counselor throughout the semester, (c) form a relationship with their counselor, and (d) develop an educational plan that would help them keep track of the courses they needed to meet their objectives. Using student experiences as evidence, the researchers highlighted the negative experiences that CCC students faced relative to assessment and placement. Nevertheless, this study did not report the ethnicities of the students in the sample.

The CCC literature discussed thus far (CCCSE, 2012; Grubb, 2006; Nodine et al., 2012; Orozco et al., 2010; Public Agenda \& WestEd, 2012; Venezia et al., 2010; 
Woodlief \& Olson, 2002; Zell, 2010) indicated that although some CCC students do not seek or receive counseling services, students who do visit counselors continue to face the overwhelming barriers they experienced in high school. Using extensive student perspectives as evidence, these studies suggested that many students experienced inaccessibility to counseling and inadequate advisement that often caused them to feel pressured, rushed, and confused about the next steps they needed to take to meet their educational goals. Constraints on counseling and access to critical information about appropriate courses and college entrance requirements can potentially limit access to higher education for low-income students and minority students (Aviles et al., 1999; Kimura-Walsh et al., 2008; Martinez, 2003). Counselors are often the only resource that first-generation low-income students and minority students have for college information (Kimura-Walsh et al., 2008; Santiago-Rivera et al., 2002). Though some students will flourish without institutional intervention, first-generation students who typically have limited access to higher education information will require more intrusive counselors support, encouragement and assistance (Bryan et al., 2009; Terenzini et al., 1994). Such support for special populations including first-generation and low-income students has been found to exist in categorical programs (programs that are state and federally funded to provide services to special populations).

Categorical support programs. Within CCC, categorical support programs such as Extended Opportunity Programs and Services (EOPS), TRIO, Puente Project, and Mathematics, Engineering and Science Achievement (MESA) have been found to play 
a key role in student success especially for first-generation and low-income students (Orozco et al., 2010; Venezia et al., 2010). Orozco et al. (2010) qualitatively analyzed how students of color who were members of specialized programs across several college campuses perceived and utilized academic advising and personal counseling. Collecting student stories and using a large sample of 363 students, the researchers found that students who were part of categorical support programs expressed high satisfaction with their counselors and described them as caring, knowledgeable, understanding of their life experiences, and always "going the extra mile" for their students. Moreover, students in this study emphasized the quality and strength of their student-counselor relationship, and indicated that through their participation in a categorical program, they had access to timely and accurate information and academic support. Though the researchers' findings were convincing in the key role that categorical support programs play in the lives of first-generation and low-income students, the voice of Latino students was not specifically highlighted. In fact, only $28 \%$ of the sample in this study were Latino.

Similarly, in a mixed methods study, Venezia et al. (2010) conducted focus groups with 257 students, interviews with 12 counselors, and telephone surveys with an unidentified number of matriculation officers to examine the policies and practices of assessment and placement in CCC and to hear students' perspectives about their assessment and placement experiences. Using extensive student voice as evidence, the researchers indicated that students who participated in categorical support programs 
reported greater satisfaction with counseling services. Students in this study expressed that categorical counselors better understood their needs, were more available to them, and provided them with more useful advice. Though the use of a large sample and student voice strengthened the researchers' findings that students who participated in categorical support programs had more positive counseling experiences, the study did not specifically focus on the counseling perspectives of Latino students.

Moreover, Grant-Vallone et al. (2004) quantitatively examined the key contributors to the social and academic adjustment of 118 first-generation and/or financially disadvantaged students in a four-year university. The researchers found that students who utilized categorical support programs had higher: (1) sense of belonging, (2) social adjustment, and (3) likelihood of staying in school. While this study focused on four-year university categorical programs, it failed to provide in-depth information about students' experiences due to its quantitative methodology.

The limited literature on categorical support programs revealed that students who participated in those programs seemed to have greater access to counseling services, often developed positive and caring long-term relationships with their counselors, and felt a sense of belonging compared to students who did not participate in such programs. Although these findings can possibly be explained by the design of categorical programs that require multiple contacts with program counselors and have low counselor-student ratios (Venezia et al., 2010), research shows that developing a 
sense of belonging based on positive relationships and diverse encounters can prevent attrition (Zell, 2010).

The importance of the student-counselor relationship. Recent research indicated that Latino students tend to experience lack of positive interactions with counselors whom they perceive to be unconcerned about their success (Eckenrod-Green \& Culbreth, 2008; Orozco, Alvarez, \& Gutkin, 2010; Zell, 2010). When students have negative perceptions of their counselors and choose not to forge relationships with them, a potential channel of support and higher education resources are diminished (Corwin, Venegas, Oliverez, \& Colyar, 2004), which are crucial to reaching degree completion. According to Valenzuela (1999), authentic caring or cariño (a deeper level of care that is similar to love, but based on respect) that nurtures and values relationships between faculty (in community college, faculty refers to counselors and instructors) and students plays a decisive role in determining students' motivation to achieve academically.

Noddings (2003) defined "care" as a "state of mental suffering or of engrossment where the one who 'cares' has a regard or inclination toward someone, is willing to spend time with that person, and is interested in what that person thinks, feels, and desires" (p.9). She further claimed that to care means "to be charged with the protection, welfare, or maintenance of someone" (p.9). It is important to note, however, that faculty does not need to establish a deep, lasting, time-consuming personal relationship with every student to demonstrate caring. Rather, caring about 
students involves a faculty member's total and non-selective presence with each student as they address or encounter them (Noddings, 2003). "The time interval in which the student meets with a faculty member may be brief, but the encounter must be total" (Noddings, 2003, p.180).

Noddings (2003) argued that faculty's willingness to advocate for students is essential to caring, and that their role is to convey acceptance through building positive relations and connections with students. Similarly, Tinto (2000) conceptually noted that interactions with faculty play a major role in students' integration within the institution. He stated that when students experienced positive interactions, they became integrated into the system and were more likely to persist and be committed to their educational goals and the institution. Still others (Cejda \& Rhodes, 2004; Zell, 2010), asserted that quality interactions and feeling "cared for" by faculty are important factors in determining minority students' persistence toward degree completion.

Given that student-counselor relationships appear to be of pivotal importance, Paniagua (2005) suggested that student-counselor relationships should be developed at three levels: conceptual, behavioral, and cultural. Paniagua (2005) noted that the conceptual level of student-counselor relationships involved students and counselors being sincere, open, honest, motivating, empathetic, sensitive, inquisitive, and credible with one another. He further indicated that the behavioral level of student-counselor relationships included students and counselors perceiving each other as competent. Finally, Paniagua (2005) suggested that at the cultural level of student-counselor 
relationships, cultural compatibility (racial/ethnic similarities between students and counselors) played a critical role in providing more effective and culturally sensitive counseling services for students. Overall, through structuring institutions around the values of caring and nurturing relationships that are based on respect, Latino students can be assisted and motivated to reach their educational objectives (Noddings, 2003; Paniagua, 2005; Tinto, 2000; Valenzuela, 1999).

\section{Conclusion}

The literature reviewed indicated that although Latino parents provide unconditional commitment to their children's education and motivate them to pursue higher education, they are often inexperienced with the college-going process and face great challenge in providing accurate information to assist their children in reaching college completion. Therefore, the literature suggests that community college counselors are in key positions to assist Latino students in navigating through the hurdles of higher education and in supporting them in their educational goals.

Although it is reasonable to expect that high quality college counseling services are available to all students as a baseline resource for academic planning, detrimental differences continue to exist in counseling services (Corwin et al., 2004). Dominated by qualitative methodological designs, the limited high school counseling literature relevant to Latino students revealed reoccurring themes that counselors (a) misinformed students about college eligibility requirements and opportunities available to them, (b) incorrectly assigned students to courses, (c) used differential treatment and advisement 
based on their assumptions regarding Latino students and their academic potential, (d) rushed students through the counseling process due to high counselor-student ratios, and (e) demonstrated a lack of genuine care for students (Aviles, Guerrero, Howarth, \& Thomas, 1999; Bryan et al., 2009; Corwin et al., 2004; Eckenrod-Green \& Culbreth, 2008; Immerwahr, 2003; Kimura-Walsh et al., 2008; Martinez, 2003; Vela-Gude, et al., 2009; Zalaquett, 2005).

Similarly, the limited research on community college counseling services indicated that Latino students and other students of color continue to face the overwhelming barriers they experienced in high school including inaccessibility to counselors due to high counselor-student ratios, inadequate advisement, and lack of genuine care (Orozco et al., 2010; Woodlief \& Olson, 2002; Zell, 2010). In contrast, campus level research done on multiple community college campuses showed that students praise categorical support programs (state funded programs that serve specific student groups) emphasizing the quality and accessibility to counseling, the caring encounters, and long-term relationships developed with their counselors (GrantVallone, Reid, Umali, \& Pohlert, 2004; Orozco et al., 2010; Venezia, Bracco, \& Nodine, 2010). The community college literature, however, focused minimally on Latino students' counseling perceptions and needs.

In general, the literature is sparse about how Latino students perceive, negotiate, and develop a relationship with community college counselors. As a result, this study is guided by the following research question: How do first-generation, low-income, Latino 
students perceive, negotiate (interpret or try to make meaning of), and develop a relationship with their community college counselor? Gathering information about Latino students' perceptions and experiences with community college counseling services will provide institutions with greater understanding about: (a) Latino students' needs as they navigate the system of higher education, (a) how student-counselor relationships motivate students to reach their educational objectives, and (c) how promising counseling practices can be used to support Latino students and continuous improvement in the $\mathrm{CCC}$ counseling field.

Exploring the counseling experiences of first-generation, low-income, Latino community college students will fill the gap in the literature and shed light on the pivotal role of counselors in motivating students to retain, persist, and complete their educational goals. More specifically, this study will share the life and counseling experiences of currently enrolled community college male, female, immigrant, and English as a Second Language (ESL) first-generation, low-income, Latino students whose experiences have not been portrayed in the current literature.

The next chapter (Chapter Three) will review the qualitative grounded theory research design that was used in this study to capture the community college counseling experiences of first-generation, low-income, Latino students. Chapter Three is presented in nine sections including: (a) research design, (b) role of the researcher, (c) research question, (d) study context, (e) participant selection, (f) ethics and protection of human subjects, (g) data collection, (h) validity, and (i) data analysis. 


\section{Chapter Three: Methodology}

\section{Introduction}

The purpose of this study was to explore how first-generation, low-income, Latino students perceived, negotiated, and developed a relationship with their community college counselor. A qualitative grounded theory research design was selected to allow for a more comprehensive exploration of Latino students' perspectives of community college counseling services. This chapter is presented in nine sections including: (a) research design, (b) role of the researcher, (c) research question, (d) study context, (e) participant selection, (f) ethics and protection of human subjects, (g) data collection, (h) validity, and (i) data analysis.

\section{Research Design}

Qualitative research can be defined as "an examination process of perceptions that investigates a social or human dilemma through building a complex and holistic picture, analyzing words, reporting detailed views of informants, and conducting the study in a natural setting" (Creswell, 2008, p. 63). Creswell (2008) indicated that qualitative research is appropriate when the researcher relies on the views of participants to gain understanding on the position they hold about an educational issue. This study employed a qualitative grounded theory research design in order to learn about first-generation, low-income, Latino students' perspectives of community college counseling services. Qualitative data were collected through semi-structured in-depth interviews which can be described as a thorough exploration of a group of individuals 
(Creswell, 2008). Interviewing is one of the most common and powerful ways to understand the experiences of participants rather than to predict or to control that experience (Seidman, 2005).

The use of a grounded theory research design (Glaser \& Strauss, 1967) in this study is guided by the research questions that allowed the researcher to focus on student experiences as it relates to students' interaction with their community college counselor. Grounded theory specifically emphasizes observing the world through the eyes of participants while developing concepts and theories that are grounded in multiple stages of data collection (Glaser \& Strauss, 1967). Hutchinson (1988) indicated that grounded theory "offers a systematic method by which to study the richness and diversity of human experience to generate relevant, plausible theory which can be used to understand the contextual reality of social behavior" (p.126). Thus, grounded theorists do not apply their ideas in an action setting. Rather, they generate an explanatory theory that emerges through constant comparative analysis where the researcher uses the data to generate concepts, categories, and variations (Glaser, 2003). In this way, predictive statements about the experiences of individuals are grounded in the data from participants (Creswell, 2008).

Using grounded theory allowed the researcher to use (a) the information from the literature review to guide the data collection and analysis, and (b) the process of constant comparisons to better organize the raw data into meaningful sets of events and re-occurring themes. The mechanics of emerging concepts coupled with continuous 
parallels to the literature create a synthesis of thought and a goal of contributing theory of knowledge at the conclusion (Glaser \& Strauss, 1967). According to Glaser and Strauss (1967), theory is a process that is ever-developing rather than a perfected product. By implementing a qualitative methodology in combination with a grounded theory design, the researcher was able to: (a) listen to the voices of Latino community college students as they shared their experiences on how they perceived, negotiated (interpret or try to make meaning of), and developed the relationship with their community college counselor; (b) freely search for constant new ideas and elements; and (c) develop theories based on themes encountered in the data collection process.

\section{Role of the Researcher}

The researcher is a first-generation bicultural Latina who is bilingual and biliterate in English and Spanish and who is currently employed at El Toro Community College District (ETCCD) (pseudonym) as counselor for Extended Opportunity Programs and Services (EOPS) and California Work Opportunity and Responsibility to Kids (CalWORKs). She has worked as a high school and community college counselor for the past ten years and has supported many students by providing them with educational, career, vocational, transfer, and personal counseling services, crisis intervention, and referral.

The researcher has experience working with first-generation, low-income, Latino students similar to those who comprise the sample of the current study. As counselor, she conducts intake interviews upon meeting with students. This experience 
assisted her in conducting participant interviews. The researcher also took two research methods courses in which interviewing was practiced and data were collected and analyzed. In addition, the researcher is a native Spanish-speaker who spent her formative years in México, lived in México in other points of her life, and took two Spanish for Spanish Speakers courses in college. Thus, being a bilingual and bicultural Latina was an asset in understanding participants, interviewing participants in their native language, and transcribing and analyzing interview data in the language in which the interview was conducted.

Moreover, as a previous community college student and as a current community college counselor, she gained a considerable amount of experiential knowledge on the challenges community college students face as they work to reach their educational objectives. Overall, she is a student advocate who is committed to improving the educational outcomes of Latino students and other under-represented students in higher education. The researcher acknowledges that as a counselor she is a gatekeeper for students who seek to reach their educational endeavors. However, she feels a great responsibility to assist students in overcoming barriers and persist to graduation and transfer.

Choosing her workplace as the study site enabled the researcher to serve as a participant-observer and quickly establish rapport, trust, and connection with study participants and instructors who allowed her to visit their classroom during the data collection process. Nevertheless, she is fully aware of her biases as a first-generation, 
low-income, Latina who (a) has similar lived experiences as the study participants, (b) attended ETCCD for part of her undergraduate career, and who (c) was part of Extended Opportunity Programs and Services (EOPS). Because of her biases and her closeness to the research setting, it became crucial for the researcher to monitor and be self-aware of how these personal biases could potentially influence the data. Thus, the researcher used several strategies to increase the validity of this study.

Prior to conducting the study, the researcher ensured that all participants were unknown to her and had never met with her for counseling services. In addition, she used a critical colleague and an inquiry auditor (Lincoln \& Guba, 1985), neither of whom were first-generation Latinos. Her critical colleague was a Filipino-American Middle School Principal who was part of her cohort in the Doctoral program at San Francisco State University. By reading her data memos, making comments, and asking questions, she assisted in neutralizing the researcher's personal biases throughout the data collection period. The researcher's critical colleague also read through detailed parts of participants' transcripts to confirm the findings of this study. The inquiry auditor who also assisted in neutralizing the researcher's biases was a Caucasian male with experience in high school and community college settings. He has been employed as a community college counselor for the past nine years and has experience with firstgeneration, low-income, Latino students. Throughout this study, the inquiry auditor was non-participant who assisted with the data coding and analysis process to ensure 
trustworthiness of the data. He also reviewed the findings chapter to make certain the report completely and accurately portrayed participants' experiences.

The researcher also used her dissertation chair to ensure the trustworthiness of the data. The researcher's dissertation chair is also a bilingual and bicultural Latina who is biliterate in English in Spanish, has translated two books on health and a number of other technical reports, and has published research related to community college counseling services. The researcher met with her dissertation chair a minimum of one time per month to ensure accuracy and trustworthiness of data translation and to discuss the findings that emerged from the data collection process.

For the entire duration of this study, the researcher used a research journal to track data, emerging understandings, and important elements related to the topic. The kinds of entries included descriptions of events that occurred in the interviews, thoughts that occurred to her that helped her understand students' experiences, policy and practice implications, unexpected occurrences, reflections, emerging questions and themes, and personal thoughts and feelings about assumptions and progress of the study. By utilizing a research journal to manage and strategize study elements and processes, the researcher was able to more easily organize the study.

During the data collection process, the researcher audio-recorded all participant interviews and produced verbatim transcripts. Participants' self-selected pseudonyms and the date of each interview were recorded in the filenames. The combination of these efforts allowed the data to be viewed more fully, from multiple angles. The 
validity of this study was supported by the triangulation of qualitative data, member checking, and the use of the researcher's critical colleague, inquiry auditor, and dissertation chair who were familiar with this study.

\section{Research Question}

How do first-generation, low-income, Latino students perceive, negotiate, and develop a relationship with their community college counselor?

\section{Study Context}

El Toro Community College District (ETCCD) (pseudonym) is a HispanicServing Institution (HSI) (a public two-year college with Latino enrollment of $25 \%$ or more full-time equivalent students) and is one of 112 public California Community Colleges (CCC) serving approximately 6,000 residents in the central coast of California. In an effort to enhance student access to a college education, ETCCD operates three instructional sites, thus increasing their curricular and student service offerings at the main campus. ETCCD serves a diverse student population. In the spring 2012 semester, over half of the student population was Latino (54\%) compared to $32 \%$ of Caucasian, 6\% Asian/Pacific Islander, 2\% African-American, .9\% Native-American, and 5\% Other/Unknown students (CCCCO, 2012a).

ETCCD employs 223 full time permanent employees and approximately 210 part-time faculty each semester. Of these permanent and part-time employees, 22 are counseling faculty of which $32 \%$ are full-time tenured employees $(n=7)$ and $68 \%$ are

part-time employees $(n=15)$. Of the seven full-time counselors, five are counselors who 
offer counseling services to the general student population. The other two are counselors from categorical programs such as Extended Opportunity Programs and Services (EOPS) and California Work Opportunity and Responsibility to Kids (CalWORKs) who offer services to students from special student populations (e.g, firstgeneration, low-income, single parents on public assistance, etc.) (Refer to Table 1 below). Moreover, of the 15 part-time counselors, $36 \%(n=8)$ are general counselors who provide counseling services to students in the generation population, while $32 \%$ are categorical counselors $(n=7)$ who serve students in categorical support programs such as Mathematics Engineering Science Achievement (MESA), Kinesiology, Disability Resource Center (DRC), and TRIO.

Table 1 ETCCD Counseling Faculty

\begin{tabular}{cccc}
\hline Counselor & $\begin{array}{c}\text { Number Employed } \\
\text { Part-Time }\end{array}$ & $\begin{array}{c}\text { Number Employed } \\
\text { Full-Time }\end{array}$ & $\begin{array}{c}\text { Total } \\
\text { Number* }\end{array}$ \\
\hline General & $8(36 \%)$ & $5(23 \%)$ & $13(59 \%)$ \\
Categorical & $7(32 \%)$ & $2(9 \%)$ & $9(41 \%)$ \\
\hline Total & $15(68 \%)$ & $7(32 \%)$ & 22 \\
\hline${ }^{*} n=22$ & & &
\end{tabular}

As illustrated in Table 1 above, of the 22 counselors employed at ETCCD, less than half (41\%) are categorical counselors (those who offer counseling services to students who are part of support programs) $(n=9)$, while over half $(59 \%)$ are general counselors (those who offer counseling services to students in the general population who are not part of specialized support programs) $(n=13)$. ETCCD is an ideal site for the study of first-generation, low-income Latino students in higher education as it offers 
a wide range of services to a majority Latino student population including (a) vocational, technical, certificate, degree, and transfer programs, (b) need-based grants, (c) tuition fee waivers, (d) student loans, and (e) student support services and programs.

\section{Participant Selection}

This qualitative study was designed utilizing purposeful sampling to obtain “information rich" (Patton, 1990, p.169) cases in order to acquire an in-depth understanding of the counseling experiences and needs of a small group of community college Latino students. Denzin and Lincoln (2008) posited that the preference of qualitative research is to study oppressed and under-developed groups. Glaser and Strauss (1967) indicated that grounded theory is particularly useful in research that seeks to examine deeply a social phenomenon based on presented information. This study is based on the pronounced gap in the literature with respect to community college counseling services, the college counseling experiences of minority, lowincome and first generation students (Orozco et al., 2010), and the research that demonstrated the low persistence rate of Latino students after their first year in college (Pascarella \& Terenzini, 2005).

Inclusion criteria. Participants were selected based on meeting the following criteria: self-identifying as (a) being Latino/Hispanic/Chicano, First-generation (their parents did not receive a baccalaureate degree from a four-year university), Lowincome based on the BOGG (Board of Governors Grant) fee waiver income standards;

(b) having completed a minimum of one semester at ETCCD; and (e) being 18 years of 
age or older. The researcher was prepared to include participants who had and/or had not met with a community college counselor. In fact, the researcher created a separate interview protocol for participants who had never met with a counselor (Refer to Appendix P). Ultimately, participants who volunteered for this study were those who had seen a community college counselor.

Exclusion criteria. Participants who did not meet the inclusion criteria and had met with the researcher for counseling services were excluded from the study. Since the researcher is currently employed as a counselor at ETCCD, she screened potential participants to ensure that they were unknown to her. The screening process involved: (a) using the El Toro College Scheduling and Reporting System (SARS) (a scheduling system that tracks students' counseling appointments) to screen that potential study participants had not received counseling services from her; and (b) excluding all participants whom the researcher identified had ever met with her for counseling services. Once potential participants were screened, the researcher then identified those who were ineligible and contacted them via email or telephone to let them know about their ineligibility to participate in the study (Refer to Appendix N).

Number of participants. This study included the participation of 26 Latino first-generation, low-income, community college students (Refer to Appendix S). Creswell (2008) indicated that typical qualitative research can include few individuals in order to gain in-depth information about the given area of study. He further stated that having a large number of cases becomes difficult to manage, and results in 
superficial perspectives. In order to define the number of participants for this study, the researcher relied on saturation, or a point were no new information could be gathered from the data collection process (Glaser, 2003).

Participant demographics. As demonstrated in Table 2 below, the ages of participants in the sample ranged from 18-23 years of age (69\%) to 36 years of age and over (12\%). The average age of participants was 24 .

Table 2

Ages of Research Participants

\begin{tabular}{cc}
\hline Age & $\begin{array}{c}\text { Number of } \\
\text { Participants* }^{*}\end{array}$ \\
\hline $18-23$ & $18(69 \%)$ \\
$24-29$ & $4(15 \%)$ \\
$30-35$ & $1(4 \%)$ \\
$36-40$ & $3(12 \%)$ \\
${ }^{*} \mathrm{n}=26$ &
\end{tabular}

Of the total participant sample, $73 \%$ were female while $27 \%$ were male. Over half of participants were single ( $77 \%)$ compared to $23 \%$ who were married $(n=6)$. Half of the participants were born in México (50\%) and slightly fewer participants were born in the United States (46\%). Of the participants born in México, all immigrated to the United States between the ages of 0 and 23. The majority of participants (65\%) were citizens of the United States, $19 \%$ were residents of California, and 15\% had no valid documentation (Refer to Table 3 below). 
Table 3

Participant Demographic Information

\begin{tabular}{|c|c|c|c|}
\hline Demographic & $\begin{array}{c}\text { Number of } \\
\text { Participants }^{*}\end{array}$ & Demographic & $\begin{array}{c}\text { Number of } \\
\text { Participants* }\end{array}$ \\
\hline Gender & & Nativity & \\
\hline Female & $19(73 \%)$ & United States & $12(46 \%)$ \\
\hline Male & $7(27 \%)$ & México & $13(50 \%)$ \\
\hline Marital Status & & Citizenship & \\
\hline Single & $20(77 \%)$ & U.S. Citizen & $17(65 \%)$ \\
\hline Married & $6(23 \%)$ & $\begin{array}{l}\text { Permanent Resident of CA } \\
\text { Non-Resident }\end{array}$ & $\begin{array}{l}5(19 \%) \\
4(15 \%)\end{array}$ \\
\hline Have Children & $8(31 \%)$ & & \\
\hline Do not Have Children & $18(69 \%)$ & $\begin{array}{l}\text { Age at Immigration to U.S. } \\
\text { 0-5 years } \\
\text { 6-11 year }\end{array}$ & $\begin{array}{l}3(23 \%) \\
3(23 \%)\end{array}$ \\
\hline & & $\begin{array}{l}12-17 \text { years } \\
18-23 \text { years }\end{array}$ & $\begin{array}{l}4(31 \%) \\
3(23 \%)\end{array}$ \\
\hline
\end{tabular}

As demonstrated on Table 3 above, $31 \%$ of participants had children $(n=8)$. Of the participants who had children, $75 \%$ lived in two-parent households $(n=6)$, while $25 \%$ were single parents $(\mathrm{n}=2)$ (Refer to Table 4 below).

Table 4

Family Composition of Participants who Have Children

\begin{tabular}{cc}
\hline Family Composition & Number of Participants* \\
\hline Two-Parent Household & $6(75 \%)$ \\
Single-Parent Household & $2(25 \%)$ \\
\hline${ }^{*} \mathrm{n}=8$ &
\end{tabular}

Half of the total number of participants who had children, was enrolled in college fulltime $(50 \%)$. However, participants' enrollment status varied by household composition (two-parent vs single parent household). For example, 100\% of participants who were single parents $(n=2)$ were enrolled in college full-time compared to $33 \%$ of participants 
who were part of two-parent families. Most participants from two-parent families were enrolled half-time (50\%) (Refer to Table 5 below).

Table 5

Enrollment Status of Participants who Have Children

\begin{tabular}{|c|c|c|c|}
\hline Enrollment Status & $\begin{array}{c}\text { Number of } \\
\text { Participants } \\
\text { in Two-Parent } \\
\text { Households* }\end{array}$ & $\begin{array}{c}\text { Number of } \\
\text { Participants in } \\
\text { Single-Parent } \\
\text { Households** }\end{array}$ & $\begin{array}{l}\text { Total Number of } \\
\text { Participants with } \\
\text { Children }\end{array}$ \\
\hline Full-time (12+ units) & $2(33 \%)$ & $2(100 \%)$ & $4(50 \%)$ \\
\hline Three-quarter time (9-11 units) & $1(12 \%)$ & 0 & $1(13 \%)$ \\
\hline Half-time (6-8 units) & $3(50 \%)$ & 0 & $3(38 \%)$ \\
\hline Total & 6 & 2 & 8 \\
\hline
\end{tabular}

Of the total sample of research participants, more than half were enrolled in college full-time $(65 \%)$ compared to $23 \%$ who were enrolled half-time, and $12 \%$ who were enrolled three-quarter time (Refer to Table 6 below).

Table 6

Participant Enrollment Status

\begin{tabular}{cc}
\hline Enrollment Status & Number of Participants* \\
\hline Full-time (12+ units) & $17(65 \%)$ \\
Half-time (6-8 units) & $6(23 \%)$ \\
Three-quarter time (9-11 units) & $3(12 \%)$ \\
\hline$*_{\mathrm{n}=26}$ &
\end{tabular}

The number of semesters that participants had completed in college ranged from two to three semesters $(38 \%)$ to more than eight semesters $(12 \%)$. The average number of semesters that participants had completed in college was four (Refer to Table 7 below). 
Table 7

Number of Semesters Completed in College

\begin{tabular}{cc}
\hline Number of Semesters & Number of Participants \\
\hline $2-3$ & $10(38 \%)$ \\
$4-5$ & $10(38 \%)$ \\
$6-7$ & $3(12 \%)$ \\
$8+$ & $3(12 \%)$ \\
${ }^{*} \mathrm{n}=26$ &
\end{tabular}

Participants' majors included Accounting Information Systems, Administration of

Justice, Architecture, Biology, Business, Child Development, Digital Media, English as a Second Language (ESL), Health Science, Music, Nursing, Natural Science, Political Science, Social Science, and Undeclared (Refer to Figure 1 below).

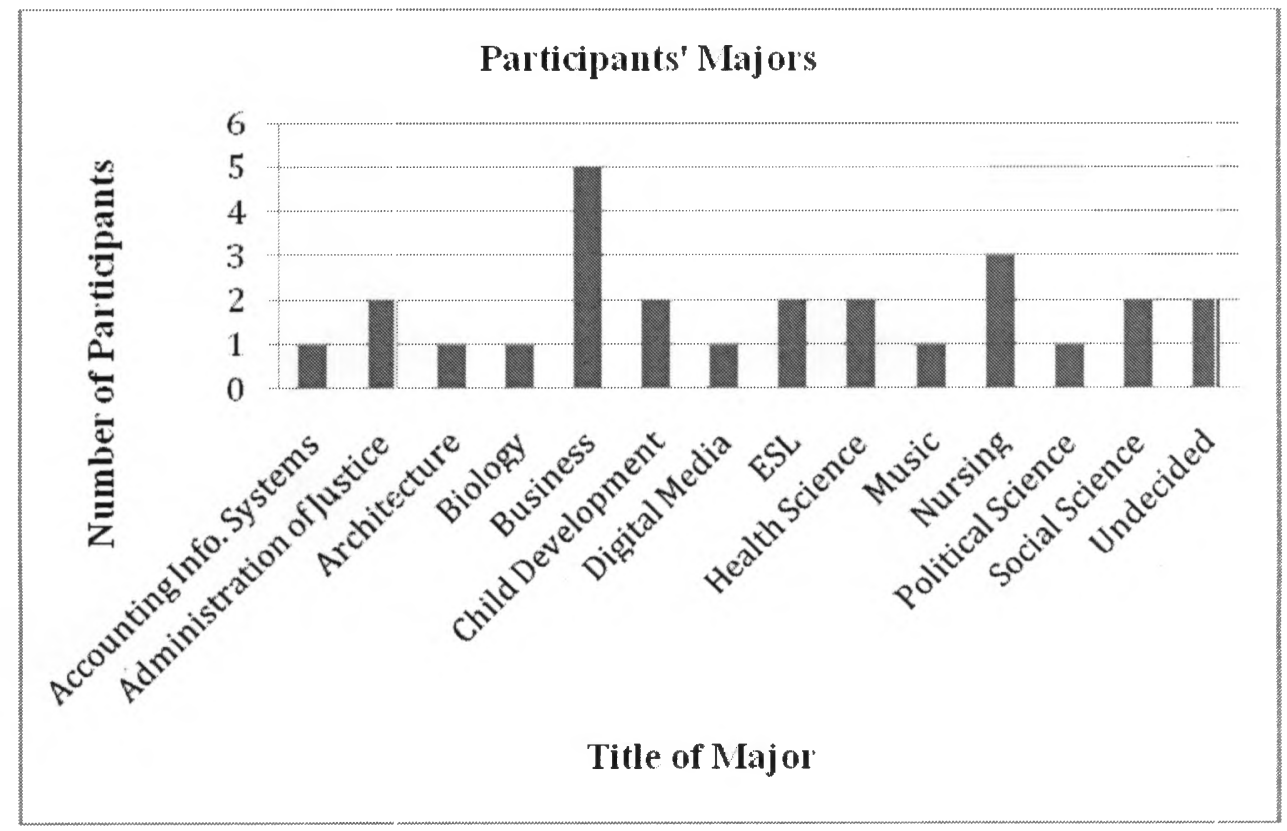

Figure 1. Participants' majors.

Forty-two percent of participants $(\mathrm{n}=11)$ were enrolled in categorical support programs such as Extended Opportunity Programs and Services (EOPS), Mathematics 
Engineering Science Achievement (MESA), TRIO, and Puente, while 58\% of participants $(n=15)$ were not part of any programs (Refer to Table 8 below).

Table 8

Categorical vs. Non Categorical Program Enrollment

\begin{tabular}{lc}
\hline \multicolumn{1}{c}{ Enrollment } & Number of Participants* \\
\hline In Categorical Support Program & $11(42 \%)$ \\
EOPS & 6 \\
TRIO** & 3 \\
MESA $^{* *}$ & 1 \\
Puente & 2 \\
In No Categorical Support Program & $15(58 \%)$ \\
\hline${ }^{*}=26$ & \\
${ }^{* *}$ One student was enrolled in both TRIO and MESA.
\end{tabular}

Slightly less than half of participants (46\%) typically met with a counselor three to four time per semester $(n=12), 38 \%$ met with a counselor one to two times per semester $(n=10)$, and $15 \%$ met with a counselor five to six times per semester $(n=4)$. Participants who were part of categorical support programs were twice as likely to meet with their counselor than those who were not part of any programs. In fact, the average number of counseling appointments scheduled per semester for participants who were part of categorical programs was four compared to two for participants who were not part of any programs (Refer to Table 9 below). 
Table 9

Number of Counseling Appointments Scheduled Per Semester

\begin{tabular}{ccc}
\hline $\begin{array}{c}\text { Number of } \\
\text { Appointments }\end{array}$ & $\begin{array}{c}\text { Participants in } \\
\text { Categorical Support } \\
\text { Programs* }\end{array}$ & $\begin{array}{c}\text { Participants in No } \\
\text { Categorical Support } \\
\text { Programs** }\end{array}$ \\
\hline $1-2$ & 0 & $10(67 \%)$ \\
$3-4$ & $8(73 \%)$ & $4(27 \%)$ \\
$5-6$ & $3(27 \%)$ & $1(6 \%)$ \\
\hline Average \# of & 4 & 2 \\
Appointments & $4{ }^{*}=11 ;{ }^{*}=15$ &
\end{tabular}

\section{Ethics and Protection of Human Subjects}

Institutional permission. Creswell (2008) posited that respecting participants and study sites and obtaining permission prior to data collection are critical ethical practices. Prior to beginning this study, the researcher followed three steps to obtain permission from two of the top leaders at ETCCD to conduct research at their institution. First, she met with the President and the Executive Vice President and Chief Instruction Officer of ETCCD to discuss the amount of time it would take to collect data at the institution, the time that would be required of participants, and how the data would be used and presented upon the completion of the study. Second, she requested official approval by providing them with a formal permission letter to recruit participants and conduct research through ETCCD. Finally, she provided them a copy of the San Francisco State University Institutional Review Board (SFSU IRB) approval (Refer to Appendix A).

Review board approval. In order to guarantee to participants that this research would cause no harm, the researcher received the necessary approval for conducting 
research involving human subjects from the Human and Animal Subjects Committee at San Francisco State University. Approval to conduct this study was granted on April 26, 2012 (Refer to Appendix A). This is a requirement that was created by legislation in the 1970 s to monitor campus-based research because of prior experiences with the abuse of humans in experiments (Creswell, 2008).

Participant permission. Participants who volunteered for the study signed an informed consent form, a statement that participants sign prior to participating in research (available in English and Spanish; Appendices B and C). By signing the informed consent form, participants agreed to become involved in the study and acknowledge that their confidentiality was guaranteed (Creswell, 2008). As part of the process for gaining participant permission, the researcher followed Seidman's (2005) suggested informed consent adapted for in-depth interviews which consisted of: (a) an invitation to participate, explaining the purpose of the study, how it would be conducted, and for how long; (b) an outline of the potential risks of discomfort that might result from taking part in the study; (c) an explicit statement that participating in the study is voluntary and that refusal to participate would carry no penalty; (d) an outline of the possible benefits of the study in general and for the participant specifically; (e) the steps that would be taken to ensure participants' identity is confidential, (f) an indication of how the researcher would disseminate the results of the research; and (g) a clarification of how to contact the researcher and the local IRB if participants had questions about their rights or anything else about the study. Creswell 
(2008) indicated that by obtaining permission and clearly communicating the purpose of the study before the data collection process, the researcher would lessen any disruption the research may cause. Therefore, during every stage of data collection, the researcher introduced herself, fully disclosed the intent and purpose of the study, reviewed the informed consent form, and allowed participants to ask questions and/or stop participation at any time. A copy of the signed informed consent form was provided to every participant.

The researcher did not provide participants with incentives for their participation in this study. Only participants whose instructor agreed to provide them with extra credit for their participation in this study, received extra credit $(n=22)$. Participants whose instructor agreed to give them extra credit for their participation in this study were asked to sign a permission agreement to contact their instructor (Refer to Appendices D and E). By signing this agreement, participants gave the researcher permission to contact their instructor upon the completion of the interview and memberchecking process so that they could be awarded extra credit in their college course.

Throughout the duration of the study, the researcher practiced strict adherence to confidentiality concerning participants. All electronic data was stored in an encrypted document on her password-protected computer. Data was kept in a locked cabinet in the researcher's office and only she had access to the data. Due to the risk of loss of privacy, the names of participants and the community college district were disguised, so as to protect the confidentiality of all participants. In fact, participants were given the 
option to choose their own pseudonyms (Refer to Appendix S). Moreover, to further protect the anonymity of participants, no names or identities will be used in any published reports of the research and transcribed data will be destroyed within three years of the completion of the study.

\section{Data Collection}

Participant recruitment. Creswell (2008) suggested that to facilitate the collection of qualitative data, the researcher must gain access to the site and obtain permission to conduct research. Though gatekeepers who control the access to possible participants could have impeded the researcher from gaining access to potential participants (Seidman, 2005), the fact that she is employed as a counselor at ETCCD facilitated the process of gaining access to the institution. Participant recruitment was conducted in two phases (May 2012 and September 2012) due to not having reached a point of saturation during the first phase of recruitment.

First recruitment phase: Summer term. The first recruitment phase began in early May 2012. The researcher began the recruitment process by emailing six college instructors from the Math, English, and History departments. The email requested permission to conduct classroom presentations in an effort to recruit participants for the study and request to speak to instructors about the possibility of providing extra credit for those who decided to participate. The email also included a brief description of the study, the inclusion criteria, the time commitment for participants, and the researcher's contact information (Refer to Appendix F). The specific courses that were targeted 
included Math (Elementary Algebra, Intermediate Algebra, and Statistics); English (Composition, Composition and Literature, Critical Reasoning and Writing); and History (U.S. History Reconstruction through the Present). Though the summer course offerings were limited, the researcher chose these courses because the majority of them, excluding elementary algebra, met the college general education course requirements for graduation. In fact, most students who are interested in completing an associate degree typically enroll in these courses during their first year in college. Moreover, since the English and Math courses selected are above "basic" level, this ensured that most students enrolled in them would have completed at least one semester in college.

Within one week of the researcher's initial email request to conduct classroom presentations, five out of six instructors responded and agreed to the request for permission to conduct a classroom presentation. Of the five instructors, three agreed to give participants extra credit for participating in the study. Classroom presentations were scheduled on a date and time that were convenient for the instructors and the researcher (Refer to Appendix G). Instructors were reminded via email about the scheduled classroom presentation one week prior. The email included the date, time, and location of the course in which the presentation would be conducted.

All classroom presentations in the first phase of the recruitment process: (a) were conducted on June 18, 2012, (b) heard by approximately 125 students, and (c) lasted approximately 10 minutes each. Conducting classroom presentations involved five steps. First, the researcher introduced herself and the reason for visiting the 
classroom. Second, she handed each potential participant a recruitment flyer that included a brief description of the study, the inclusion criteria, the time commitment for participants, and her contact information (Refer to Appendices $\mathrm{H}$ and I). Third, she provided a brief explanation of the study and reviewed the information on the flyer. Fourth, she provided time for questions. The researcher concluded by reminding potential participants to contact her if they were interested in participating in the study. Throughout the process, the researcher referred to the recruitment script (Refer to Appendix J) to ensure she did not miss any information. After each classroom presentation, the researcher sent each instructor an email thanking them for allowing the opportunity to present her study in their classroom.

Upon conducting the classroom presentations, 12 interested participants contacted the researcher via email and telephone indicating a desire to participate in the study. Prior to setting up an interview date, the researcher responded to participants' email and/or telephone call and asked them to answer ten questions that would allow her to (a) verify the inclusion criteria, (b) determine if participants had previously received counseling services, (c) keep track of the type of counseling services received by participants (categorical, general, or none), (d) determine if they would be eligible for extra credit for their participation in the study, and (e) confirm that they would be sent an email with a possible interview date (Refer to Appendices K and L). During this process, all participants responded with the answers to the questions, yet only 11 out of the 12 interested participants were eligible for the study. Throughout the 
recruitment process, the researcher used her research journal to keep track of potential participants who indicated an interest to participate in the study. The researcher kept track of the students' name, email/phone number, student ID number, type of counseling service received, the name of their summer instructor, and the date and time of the agreed upon interview. Via email and/or phone, all participants were reminded about their scheduled interview two days prior to the date. A total of 11 participants were interviewed during the first recruitment phase.

Second Recruitment Phase: Fall Term. The second recruitment phase began in early August 2012. This phase of recruitment was necessary to reach a point of saturation and capture additional students that would allow the researcher to have equal representation of categorical and general students. During this phase of recruitment, the researcher began by emailing eleven instructors from the English, Psychology, History, and English as Second Language (ESL) departments. The researcher used the same format of the email sent in the first recruitment phase (Refer to Appendix F). The specific courses that were targeted included English (Practical Writing, Composition, Composition and Literature, Critical Reasoning and Writing), Psychology (Introduction to Psychology); History (U.S. History through Reconstruction, U.S. History Reconstruction through the Present, History of Western Civilization); and ESL (Listening/Speaking I \& II, Reading/Vocabulary I \& II, Intermediate ESL Grammar/Writing II, Advanced ESL Composition I, Advanced ESL Grammar I). The researcher chose these courses in order to provide continuity with the first phase 
recruitment and because the majority of the courses, excluding Practical Writing and ESL, meet the college general education course requirements for graduation. In fact, most students who are interested in completing an associate degree typically enroll in these courses during their first year in college. Although, the ESL courses do not meet college graduation requirements, they were chosen to include the voice of this student population and to reach a point of saturation. Moreover, since the English and ESL courses selected are above "basic" level, this ensured that most students enrolled in them had completed at least one semester in college.

Within one week of the researcher's initial email request to conduct classroom presentations, eight instructors responded and agreed to the request, one did not agree to the request, and three did not respond. Of the eight instructors who agreed to the request, five agreed to give participants extra credit for participating in the study. Via email, classroom presentations were scheduled on a date and time that were convenient for the instructors and the researcher (Refer to Appendix G). Instructors were reminded via email about the scheduled classroom presentation one week prior. The email included the date, time, and location of the course in which the presentation would be conducted.

Classroom presentations in the second phase of recruitment were (a) conducted between September 5, 2012 and September 17, 2012,(b) heard by approximately 225 students, and (c) lasted approximately 10 minutes each. Classroom presentations were conducted following the same process reviewed in the first phase of recruitment with 
the exception that one out of three ESL classroom presentations was conducted in Spanish while the other two were conducted in English based on the instructors' request. After each classroom presentation, the researcher sent each instructor an email thanking them for allowing her the opportunity to present her study in their classroom.

Upon conducting the classroom presentations, 24 students contacted the researcher via email and telephone indicating an interest to participate in the study. Of the 24 students who indicated an initial interest, four did not respond to the participant recruitment verification (Appendices $\mathrm{K}$ and $\mathrm{L}$ ), and five were put on a waitlist due to the researcher already having had scheduled interviews (Refer to Appendix M). During this phase of the data collection process, the researcher determined students' eligibility for the study and kept track of this data following the same process she used in the first phase of recruitment. A total of 15 participants were interviewed during the second recruitment phase.

Overall, during the recruitment process in summer 2012 and fall 2012, the researcher (a) contacted a total of 17 instructors of which $76 \%$ agreed to the researcher's request to recruit participants $(n=13)$, and $62 \%$ agreed to give students extra credit for their participation in the study $(n=8)$ (Refer to Appendix G); and (b) conducted classroom presentations in 13 classrooms for approximately 350 students of which $10 \%$ responded $(n=36)$ and $7 \%$ participated in the study $(n=26)($ Refer to Appendix S). It is important to emphasize that the final participant sample was 
determined based on having reached a point of saturation where no new information appeared to be emerging.

\section{Instrumentation}

The current study employed semi-structured in-depth interviews with Latino students attending ETCCD about their perceptions of counseling services. Semistructured in-depth interviews are used when the interviewer has a framework of themes (aggregated codes that form a major idea) to be explored (Patton, 2002) and are especially useful when analyzing participants' experiences and perceptions (Patton, 1990). According to Corbin and Strauss (2008), the researcher is considered the instrument of data collection in grounded theory research. Thus, in this study the researcher conducted face to face in-depth interviews and became an attentive listener who elicited rich detailed material that could be used in analysis (Lofland \& Lofland, 1995). The researcher initially had two interview protocols that would be used with participants depending on whether or not they had received counseling services (Refer to Appendices $\mathrm{O}$ and $\mathrm{P}$ ). However, given that the final study sample consisted of students who had received counseling services, the researcher used the protocol intended for students who had received counseling (Refer to Appendix O). The student interview protocol used included 20 questions and it was divided into two parts: (a) an introduction that collected demographic information and students' perceived support from family, and (b) an exploration of students' perceptions of college counseling 
services. Interview questions were derived from the literature and previous research (Refer to Appendix O).

Interviews. The interviews with the 26 participants took place at the ETCCD campus in mid June 2012 and early September of 2012. Eleven participants were interviewed during June 2012, while 15 participants were interviewed in September 2012 until a point of saturation was reached. This point of saturation was reached during the second recruitment phase when themes were re-occurring in participants' responses and no new information was being gathered. Having reached a point of saturation, it was logical to stop interviewing participants.

Participant interviews lasted approximately 60 minutes, took place between $8 \mathrm{am}$ and 7pm depending on participants' availability, and were conducted in English and Spanish depending on the language preference of participants. During the interviewing process, the researcher used a semi-structured interview protocol (Refer to Appendix O). To conduct in-depth interviews, Lofland and Lofland (1995) suggested selecting a setting that provides privacy for participants and a location that is comfortable, nonthreatening, easily accessible for participants, and distraction-free. Interviews were therefore scheduled in a meeting room on the college campus. Participants were reminded about their scheduled interview one day prior via email and/or phone. Participants unable to attend the scheduled interview time and date were rescheduled for a different date through a follow up email and/or telephone call. Students were not asked to miss class to participate in this study. 


\section{Validity}

In order to increase the validity of this study and ensure the accuracy of the data, the researcher utilized seven steps. First, the participant inclusion/exclusion criteria specifically controlled who participated in the study (Creswell, 2008). Second, interview questions were piloted with four Latino participants during the fall term of 2011. Piloting the questions gave the researcher the ability to make any necessary revisions to questions that were unclear or unnecessary. Third, the researcher used a critical colleague to assist in neutralizing her personal biases throughout the data collection. This critical colleague read the researcher's data memos, made comments, asked questions, and read through detailed parts of participants' transcripts to confirm the findings of this study. Fourth, an inquiry auditor was involved with the data coding and analysis process of this study to ensure trustworthiness of the data. Lincoln \& Guba (1985) defined an inquiry auditor debriefing as "a process of exposing oneself to a disinterested peer in a manner paralleling an analytic session and for the purpose of exploring aspects of the inquiry that might otherwise remain only implicit to the researcher" (p.308). Fifth, trustworthiness of the results was validated through memberchecking in follow-up correspondence with all participants (Refer to Appendix Q). Lincoln \& Guba (1985) called "member-checking" a process through which participants verify data resulting in interpretation. The researcher conducted the member checking process within two weeks of the initial interview by emailing each study participant a copy of their transcript. Through member checking participants were given the 
opportunity to review the transcript, add additional information they had not mentioned in the interview, and approve a final version. Once participants completed the member checking process, their college instructor was contacted via email to let him/her know that they had completed the requirements of the study and were eligible to receive extra credit in the course. Each participant was copied on the email sent to instructors. This process was necessary to ensure validity and establish credibility. Sixth, the researcher met with her dissertation chair a minimum of one time per month to ensure accuracy and trustworthiness of data translation and to discuss the findings that emerged from the data collection process. Finally, the researcher used a research journal to track data, emerging understandings, and important elements related to the study. Lincoln and Guba (1985) noted that reflections provide descriptive data to create transparency that can be utilized by consumers of research to establish the transferability of the researcher's findings. The validity of this study was supported by the triangulation of qualitative data, member checking, and the use of the researcher's critical colleague, inquiry auditor, and dissertation chair who were familiar with this study. Overall, the qualitative findings are applicable to other Latino students in community college settings with similar demographics.

\section{Data Analysis}

Interview data were audio-recorded so that the researcher was able to be fully present with the participants, and so that no information was missed through note-taking (Lofeland \& Lofeland, 1995). Through audio-recording, the researcher preserved the 
words of participants, and had the original data available to check for accuracy (Seidman, 2005). After each interview, the researcher completed verbatim transcriptions of the audio-recorded data using Microsoft Word. Transcription is the process of converting audio-recorded information into word-for-word text data which allows for data analysis (Creswell, 2008). Transcriptions were first completed in the language in which the interview was conducted (English or Spanish). The researcher then translated Spanish transcriptions into English for the use of inquiry auditor who was not Spanish-speaking. Since the researcher is bilingual and biliterate in English and Spanish, she was able to work with all raw data without utilizing the translated transcriptions that she provided the inquiry auditor. By having a verbatim transcript, the researcher and the inquiry auditor were able to fully reflect on the interview themes and have an objective record of the interview data collection process (Seidman, 2005).

Data analysis for this study was conducted using seven steps. First, transcribed data was read using a "preliminary exploratory analysis" (Creswell, 2008, p.250) which involved reading the data to get a general sense of the transcripts and to begin thinking about the ways in which the data would be organized. Second, open coding was used to form initial categories of information by re-reading the transcripts indexing key words and phrases from the interview protocol and writing short memos consisting of phrases, terms, and thoughts in the margin of the transcripts (Corbin \& Strauss, 2008; Creswell, 2008; Patton, 2002). Third, codes were aggregated and organized to form major themes or ideas based on simple frequency counts, calculated by the number of times students 
report certain experiences or perceptions (Creswell, 2008). Fourth, axial coding was used by scrutinizing the transcript line-by-line, coding the data, and organizing the material into concepts (Corbin \& Strauss, 2008). Axial coding was a continual process until saturation was accomplished. Fifth, the constant comparison approach, or the continual evaluation of data, was used throughout to compare new elements of data with previously coded data, which refined emerging themes (Corbin \& Strauss, 2008; Patten, 2009). Sixth, through the use of selective coding, all of the core categories were integrated to generate a comprehensive theory that was grounded in the data (Corbin \& Strauss, 2008). Finally, charts were created to organize and cluster themes and supporting direct quotations in a clear and logical manner (Patton, 2002) (Refer to Appendix R). Throughout the data coding process, the researcher and the inquiry auditor coded the data independently and analyzed the data coding results together via weekly telephone, email, and/or face-to-face meetings. The researcher and inquiry auditor agreed on the coding $90 \%$ of the time. When there was disagreement, interpretations were presented and a mutual decision was made of the appropriate code.

\section{Conclusion}

This chapter reviewed the qualitative grounded theory research methods that were used in this study to capture the community college counseling experiences of first-generation, low-income, Latino students. The next chapter (chapter four) will share the voices of the 26 first-generation, low-income, Latino community college study participants. Chapter four reveals the research findings that are organized into 11 
sections including: (a) student's motivación [motivation] to attend college, (b) the support of la familia [the family] in students' pursuit of higher education, (c) barriers of la familia [the family] to providing academic assistance and advice for students, (d) the importance of community college counseling in supporting students, (e) students' perceptions about the role of community college counselors, (f) characteristics of un buen consejero[a good counselor] in community college, (g) students' positive community college counseling experiences, (h) students' negative community college counseling experiences, (i) students' hindrances to seeking community college counseling services, (j) students' consejos [advice] for community college counselors, and $(\mathrm{k})$ a theoretical model for students' perspectives of community college counseling. Chapter four will conclude with a summary of the findings. 


\section{Chapter Four: Report of Findings}

\section{Introduction}

The purpose of this study was to explore how first-generation, low-income, Latino students perceived, negotiated, and developed a relationship with their community college counselor. A qualitative grounded theory research design was used to allow for a more comprehensive exploration of Latino students' perspectives of community college counseling services. The research uncovered the experiences of 26 first-generation, low-income, Latino community college students captured though faceto-face semi-structured in-depth interviews.

The semi-structured in-depth interview protocol used to interview participants consisted of 20 questions (Refer to Appendix O). This chapter covers participants' responses to questions five through seven and nine through 20 from the semi-structured in-depth interviews. Questions one through four and question eight of the interview protocol were excluded from this chapter and incorporated in chapter three because they were more relevant to the description of the participant sample. In addition, question 12 and questions 15 through 17 of the interview protocol were grouped together because they were all related to the positive community college counseling experiences described by participants. Similarly, questions 18 through 20 were also grouped together because they were all relevant to participants' advice for community college counselors. 
The findings of this study support Nodding's (2003) and Valenzuela's (1999) caring theoretical framework. This framework postulates the need for institutions to be structured around the values of caring and nurturing relationships that are based on respect to meet the needs of Latino students. The findings are organized into 11 sections including: (a) student's motivación [motivation] to attend college, (b) the support of la familia [the family] in students' pursuit of higher education, (c) barriers of la familia [the family] to providing academic assistance and advice for students, (d) the importance of community college counseling in supporting students, (e) students' perceptions about the role of community college counselors, (f) characteristics of un buen consejero [a good counselor] in community college, (g) students' positive community college counseling experiences, (h) students' negative community college counseling experiences, (i) students' hindrances to seeking community college counseling services, (j) students' consejos [advice] for community college counselors, and $(\mathrm{k})$ a theoretical model for students' perspectives of community college counseling. This chapter will conclude with a summary of the findings.

Students' Motivación [Motivation] to Attend College Question 5: What motivated you to attend college?

Pursuing higher education for the completion of a degree was an important goal that $100 \%$ of participants in this study wanted to accomplish. Participants specifically mentioned a motivación [motivation] to attend college based on (a) the struggles they experienced growing up, (b) parental sacrifices and advice, (c) their desire for a better 
job and a better life, and (d) their aspiration to become role models for their siblings, relatives, and/or their children (Refer to Table 10 below). The way in which participants' motivación [motivation] to attend college will be narrated below will not follow the strength of the responses as represented in Table 10 below. Rather, to better reflect participants' story, their motivación [motivation] to attend college is ordered as follows: (a) struggles experienced growing up, (b) parental sacrifices and advice, (c) desiring a better job, and (d) desiring a better life.

Table 10

Participants' Motivación [Motivation] to Attend College

\begin{tabular}{|c|c|c|c|}
\hline Category & Code & Code Definition & $\begin{array}{l}\text { Number of } \\
\text { Responses* }\end{array}$ \\
\hline Better Life & BtrLf & $\begin{array}{l}\text { Wanting a better life for themselves and their children } \\
\text { than they had growing up, being better able to } \\
\text { communicate with others, becoming independent, and } \\
\text { thus a role model for their siblings, relatives, and/or } \\
\text { their children. }\end{array}$ & $26(100 \%)$ \\
\hline Better Job & BtrJb & $\begin{array}{l}\text { Wanting a job that provided: (a) the ability to work } \\
\text { Monday through Friday, (c) the flexibility to spend } \\
\text { time with family, (d) monetary stability, and (e) } \\
\text { satisfaction. }\end{array}$ & $20(77 \%)$ \\
\hline $\begin{array}{l}\text { Struggles } \\
\text { Experienced } \\
\text { Growing Up }\end{array}$ & Strug & Poverty, lack of stability, financial constraints. & $16(62 \%)$ \\
\hline $\begin{array}{l}\text { Parent } \\
\text { Sacrifices }\end{array}$ & PrntSacr & $\begin{array}{l}\text { Sacrifices made by parents (immigrating from Mexico } \\
\text { to the U.S., working multiple jobs) combined with } \\
\text { their encouraging statements provided motivation to } \\
\text { attend college. }\end{array}$ & $11(42 \%)$ \\
\hline
\end{tabular}

Struggles experienced growing up. As demonstrated in Table 10 above, $62 \%$

$(n=16)$ of participants indicated that they were motivated to attend college based on the 
struggles they experienced growing up including: (a) poverty, (b) lack of stability, and (c) financial constraints.

Poverty. Of the participants who indicated that they were motivated to attend college based on the struggles they experienced growing up, 56\% recalled growing up in poverty $(n=9)$. Poverty was especially extreme for participants who immigrated from México to the United States after the age of $15(n=6)$. In fact, these participants recalled their life in México as muy triste [very sad] given that they had to give up their education and began working at a young age to assist their family financially. Crecimos en mucha pobreza. . Empecé a trabajar antes de los 12 años y lo más difícil era comer porque a veces no comíamos . . . no teníamos zapatos . . Yo me acuerdo cociendo los huaraches de plástico que teníamos para mis hermanos porque ya no había. . siempre estábamos en esa situación donde no había dinero . . y ya no pude seguir estudiando. [We grew up in poverty. I started working before the age of 12 and the hardest thing was eating because sometimes we wouldn't eat ... we didn't have shoes ... I remember stitching my siblings' plastic sandals because we didn't have anything ... we were always in that situation where there was no money . . . so I couldn't continue my education] (Cristina, 6/28/12, Question 1).

Similarly, Alejandra recalled having more than frijoles [beans] on the table only during la temporada de la cosecha [the harvest season]. 
Crecimos muy pobres. Había veces que carecíamos de comida. . . Mi papá sembraba lechuga, calabaza, chile, cebolla, frijol. Y cuando era temporada de la cosecha, de ahí comíamos, pero cuando no, pues lo único que comíamos eran frijoles... A veces hasta teníamos que ir a los ranchos más cercanos a pedir para tener que comer... Como tenía que trabajar en el campo para poder sobrevivir, no pude terminar mis estudios. [We grew up very poor. There were times when we had no food ... My dad planted lettuce, squash, peppers, onions, beans. And when it was harvest time, we ate, but when it wasn't, then all we ate was beans. Sometimes we even had to go the nearest farms to ask for food... Since I had to work in the fields to survive, I was unable to finish school] (Alejandra, 9/20/12, Question 1).

Mario recalled working alongside his nine siblings to pay for household expenses after his mother and father divorced. His family was forced to relocate to a different city in México, thus he stopped attending school.

Yo empecé a trabajar a los ocho años... Teníamos que trabajar toda la familia juntos. A veces nos íbamos a trabajar al tianguis a las cuatro o cinco de la mañana. Entre todos pagábamos los gastos de la casa. Desafortunadamente ninguno terminamos el estudio . . era más importante trabajar que estudiar porque si no, no había para comer. [I started working at age eight ... The whole family had to work together. Sometimes we went to work at the market at four or five in 
the morning. Together we paid the household expenses. Unfortunately, none of us finished school ... working was more important than going to school because if not, we wouldn't have anything to eat] (Mario, 6/26/12, Question 1).

Overall, participants who lived in extreme poverty indicated that they had to grow up fast given that they had to give up their childhood and their dream of pursuing an education in order to help pay for household expenses. Aside from living in poverty, participants also struggled with lack of financial and home stability.

Lack of stability. Of the participants who indicated that they were motivated to attend college based on the struggles they experienced growing up $(n=16), 50 \%$ recalled living in constant worry about their stability $(n=8)$ (Refer to Table 10). In many cases, participants had to move constantly from home to home due to their family's lack of financial stability. "The worry of money was always with me and always in the back of my mind" (Alexzander, 9/20/12, Question 1). "Growing up I always had worries and concerns about the everyday things that we needed ... We moved around a lot because my parents just couldn't afford rent" (Sophia, 9/24/12, Question 1). "Every few years we'd have to stop paying the rent and eventually move to another house. And it was like a constant thing ... it was a hassle ... and I kept having to adjust to that" (Ernesto, 9/24/12, Question 1). The lack of stability caused participants to experience financial constraints in their household. 
Financial constraints. As portrayed in Table 10 , of the $62 \%$ of participants who cited struggles growing up, $100 \%(n=16)$ indicated that they experienced financial constraints and recalled being limited on what they ate, what they purchased, and activities in which they participated. Participants said, "Growing up, I was taught to never eat as much as I could from the fridge and to conserve money for buying clothes and take care of ourselves" (Alexzander, 9/20/12, Question 1). "But even with buying clothes and other things, we always had to limit ourselves ... my parents always told me we had to wait" (Jade, 9/20/12, Question 1). "Sometimes I would have to wait a couple of weeks or sometimes not get what I wanted at all” (Rob, 6/21/12, Question 1). "Most of the time we had to go put school clothes and other stuff on layaway at WalMart" (Genesis, 6/21/12, Question 5). "It was hard always being limited . . . I couldn't even participate in like cheerleading or other things because we didn't have money to do it" (Lili, 6/29/12, Question 5). Although participants experienced poverty, lack of stability, and financial constraints growing up, they were motivated to pursue a degree based on their belief that a college education would lead them to a more successful future. This belief was highly instilled by their parents who made various sacrifices and advised them to pursue higher learning.

Parental sacrifices and advice. Participants' motivation to attend college was also instilled by their parents. In fact, $42 \%$ of participants $(n=11)$ indicated that they were motivated to attend college based on the sacrifices their parents made for them and the advice that they gave them about the benefits of pursuing a higher education (Refer 
to Table 10). Participants mentioned that their parents shared their stories of struggle and gave them encouragement to pursue higher education. Participants further explained that in their household, la educación [education] was a priority over work and all other activities.

My family embedded in me that I was never gonna get anywhere if I didn't have an education. The number one rule in our house was school comes first no matter what. Even to this day my mom has always told me, if you feel you can't work and go to school, I don't want you to choose work over school (Yvonne, 9/26/12, Question 5).

Participants were persuaded by their parents that if they went to college, they would not have to matarse [kill themselves] in a dead end job as they had been their entire lives. "My mom always told us that with school we wouldn't have to work on weekends or at stores or anything like that" (Emily, 6/27/12, Question 5). Participants were also convinced by their parents that with an education, they would not have to estar batallando [be struggling] to make ends meet. "My parents would always tell me, look at the struggle that we're going through, you don't want to go through that same struggle. And by going to school and getting a better education, it gets you a better job and you won't have to struggle" (Sophia, 9/24/12, Question 5). Overall, participants indicated that their parents wanted them to "get a job way better than the jobs they had" (Fred, 9/21/12, Question 6). 
Participants' parents also convinced them that with a college education, they would (a) earn more money, (b) gain higher knowledge, and (c) become independent. One participant indicated, "My parents tell me that with an education I can do more for myself . . . I'll have more knowledge than them, I'll be able to earn a degree, and get more money" (Quetzalcoatl, 9/13/12, Question 5). Another participant added, "They want to see me as a better person with a big future and not to depend on anybody" (Jade, 9/20/12, Question 5).

Participants also indicated that they were motivated to attend college due to their parents having made the sacrifice to immigrate to the United States so that they could have a better future.

My mom came here for us. She could of gone back to México, but she stayed because she thought it would be cheaper to go to school and to learn another language. So, I just want to improve myself and make my mom proud. Because she did a lot of sacrifices and I know that it will make her proud and make her feel that it was worth her sacrifice to stay here (Jessica S., 9/12/12, Question 5). For participants, attending college was a way to prove to their parents that the sacrifice they had made to relocate to a foreign country had not been in vain. In fact, they were willing to take advantage of being in this country to pursue the educational opportunities their parents did not have access to. "My parents left the only home they knew and risked all of our lives in the search for a better future for us. I can make that sacrifice count by getting a college education" (Esperanza, 9/17/12, Question 5). 
Overall, participants indicated that their parents highly valued education and instilled the belief that going to college would open doors to better job opportunities, a better future, and a high paying career that would lead them to become someone important in life. Participants indicated that they were also motivated to attend college because they desired a better life and a better job than their parents and other extended family.

Desiring a better job. A majority of participants in this study $(77 \%)$ indicated a motivation to attend college for a better job $(n=20)$. Participants defined a better job as one that provided: (a) the ability to work Monday through Friday, (b) the flexibility to spend time with family, (c) monetary stability, and (d) satisfaction. (Refer to Table 10). Participants expressed that pursuing an education would possibly allow them to have a job that was enjoyable, well-paid, and that allowed the flexibility necessary to spend time with their families; unlike their parents' lives.

Me quiero superar, porque quiero estar trabajando en un lugar que me guste y ganar bien. Quiero un trabajo donde le pueda dar lo necesario a mis hijos y donde no tenga que sacrificar el tiempo con ellos. [I want to succeed because I want to work in a place I like and that pays well. I want a job where I can give my children what they need and where I don't have to sacrifice my time with them] (Dulce, 9/18/12, Question 5).

Participants also mentioned desiring a better job than their family members had, so they would not have to live paycheck to paycheck. 
My cousins, aunts, and uncles, and most of my family all work in either construction, or factories, or stores ... my mom gets paid minimum wage and doesn't have any benefits ... I work in retail and I couldn't imagine being there stuck my entire life. It makes me want to push myself because I don't want that life for myself ... I want something more ... I really wouldn't want to be living paycheck to paycheck (Rob, 6/21/12, Question 5).

Participants not only believed that education would lead them to obtaining a better job, but they also trusted that an improvement in employment would lead to an enhanced quality of life.

Desiring a better life. All study participants ( $\mathrm{n}=26,100 \%)$ indicated that they were motivated to attend college to have a better life. Participants defined a better life as one where they (a) lived differently than growing up (b) communicated better with others, (c) gained independence, and (d) became role models (Refer to Table 10).

A life better than the life growing up. All participants ( $\mathrm{n}=26,100 \%)$ expressed that they were motivated to attend college because they wanted a different life than they had growing up. "I want a different life than my parents' lives. I remember my mom and dad always coming home from work really late and tired and my dad coming back sunburned because he worked outside. I don't want that" (Jade, 9/20/12, Question 5). "I want to do better for myself. I'm determined and I'm motivated to just do well and be well and to have the things that I wasn't able to have growing up because of my mother's circumstances" (Genesis, 6/21/12, Question 5). 
Participants also indicated wanting to offer their own families a better life than their parents were able to provide them. "I want a good job that will allow me to give my children that warmth and love that I feel I didn't really have from my parents because of our financial struggles" (Faith, 9/13/12, Question 5). Ernesto shared, I know that if I did go to college and graduate I will have more money so that I won't have to worry about spending time with my kids or having enough money to support myself or my family like my parents did (9/24/12, Question 5).

Aside from desiring a better life than they had growing up, participants also stated that they wanted a better life where they were better able to communicate with others.

A life with better communication. Of the participants who indicated being motivated to pursue a college education for a better life $(n=26)$, five participants mentioned desiring a life with better communication $(n=5,19 \%)$. It is important to note, however, that the five participants who desired a life with better communication were currently or at one point in their educational career part of the English as a Second Language (ESL) program. These participants $(n=5)$ expressed that they wanted a better life where they could communicate with others without being put down, made fun of, or feeling insecure about themselves.

I'm tired of people putting me down because English is my second language. I'm tired that I'm always being corrected by my kids, by my husband, by my sisters ... I want to be able to write, to say what I want in the right way, and say 
exactly how I feel and for people to understand what I wanted to say. Bottom line, without education you're nothing. The reward of having the knowledge and the ability to communicate is why I'm here (Marisol, 9/18/12, Question 5).

Participants also indicated wanting a better life that involved gaining independence.

A life with independence. All participants $(\mathrm{n}=26,100 \%)$ indicated that they were motivated to attend college because they wanted a better life where they were able to gain independence. Participants expressed that having a better life through obtaining higher education meant gaining the ability to become independent and self-reliant.

I just want to be independent ... All my family, my cousins, my aunts, everybody they just went straight into jobs, or they got pregnant or married with a man and had them take care of them, and their lives are just not the greatest.

So I just decided I didn't want to be like that. So I was like, I'm gonna go to college (Faith, 9/13/12, Question 5).

Participants also said that they wanted a better life where they could be role models for their younger siblings, relatives, and/or their own children.

A life as a role model. All participants (n=26, 100\%) were motivated to attend college because they wanted to lead a better life where they could become role models. By listening to their parents' advice that a college education would lead them to una mejor calidad de vida [a better quality of life], they too hoped to directly and indirectly instill those values for education in their younger siblings, relatives, and/or their own 
children. In fact, participants strived to be un modelo ejemplar [an exemplar role model].

Soy la mayor en mi casa, so también quiero que mis hermanos me vayan mirando como modelo. Ahorita que ya tengo mi bebe yo quiero que el día de mañana que él empiece a ir a la escuela yo le pueda decir con pruebas o con más fortaleza, mijo tienes que ir a la escuela y tienes que aprovechar. Y que él me mire como ejemplo también. [I'm the oldest in my house, so I also want my siblings to see me as role model. Now I have a baby and when he starts going to school I'd like to be able to say with proof and strength, son you have to take advantage and go to school. I want him to also see me as a role model (Yadira, 6/25/12, Question 5).

Of the eight participants who were parents, $100 \%$ of them expressed that their primary motivation for attending college was their children. They mentioned that they viewed a college education as una oportunidad [an opportunity] for themselves and their children and a means to offer them algo mejor [something better] or una mejor vida [a better life].

Mis hijos son mi mayor motivación. Yo quiero darles ese ejemplo de que me gusta estudiar para que ellos quieran ir a la universidad y quieran seguir con su educación. [My children are my biggest motivation. I want to show them by 
example that I like studying so that they are motivated to go to a university and continue their education] (Dulce, 9/18/12, Question 5).

Yo quiero que ellos vean que aunque tengo la dificultad del idioma y que no fui a la escuela. . estoy tratando. Quiero que ellos puedan ver que ellos en este país teniendo todo eso lo pueden lograr. [I want them to see that although I have difficulties with the language and I didn't go to school ... I'm trying. I want them to see that in this country having all that, they can do it] (Cristina, 6/28/12, Question 5).

I think that if I go to school, my kids will have a chance to become something better. They will have an education ... And what I realize is that no matter what, the education that you get no one will take it away from you (Marisol, 9/18/12, Question 5).

As indicated by participants, the primary motivators for enrolling in college included (a) the struggles they experienced growing up, (b) parental sacrifices and advice, (c) their desire for a better job and a better life, and (d) their aspiration to become role models for their siblings, relatives, and/or their children. This motivation to attend college was found to be highly supported by participants' families including their parents, siblings, and extended family as described below. 
The Support of La Familia [the Family] in Students' Pursuit of Higher Education Question 6: Tell me about the support you receive from your family to attend college.

All participants in this study mentioned at least one person in their family as a main source of support and encouragement in their pursuit of a college degree. Support from la familia [the family] included the backing of their mother, father, husband, siblings, and/or extended family. Of these support systems, the support of the mother and the husband were mentioned with the highest frequency (Refer to Table 11 below).

Table 11

Support of La Familia [the Family] in Students' Pursuit of Higher Education

\begin{tabular}{|c|c|c|c|c|c|}
\hline Category & Code & Code Definition & Frequency & $\begin{array}{c}\text { Number of Participants } \\
\text { with Family Member }\end{array}$ & Percent \\
\hline $\begin{array}{l}\text { Mother } \\
\text { Support }\end{array}$ & $\mathrm{MoS}$ & $\begin{array}{l}\text { A main source of } \\
\text { emotional, moral, and } \\
\text { financial support. } \\
\text { Mothers provided } \\
\text { advice, encouragement, } \\
\text { praise, and watched } \\
\text { their grandchildren. }\end{array}$ & 18 & 24 & $75 \%$ \\
\hline $\begin{array}{l}\text { Husband } \\
\text { Support }\end{array}$ & HusS & $\begin{array}{l}\text { Primarily a source of } \\
\text { financial support for } \\
\text { participants who are } \\
\text { married. }\end{array}$ & 6 & 6 & $100 \%$ \\
\hline $\begin{array}{l}\text { Sibling } \\
\text { Support }\end{array}$ & SibS & $\begin{array}{l}\text { Older siblings provided } \\
\text { encouragement, advice, } \\
\text { academic assistance, } \\
\text { and financial support. }\end{array}$ & 5 & 5 & $100 \%$ \\
\hline $\begin{array}{l}\text { Extended } \\
\text { Family } \\
\text { (Aunts, } \\
\text { uncles, } \\
\text { godparents, } \\
\text { grandparents) }\end{array}$ & ExFmS & $\begin{array}{l}\text { Primarily a source of } \\
\text { financial support. } \\
\text { Supported participants' } \\
\text { education by offering } \\
\text { praise and offering to } \\
\text { watch their children. }\end{array}$ & 4 & 26 & $15 \%$ \\
\hline $\begin{array}{l}\text { Father } \\
\text { Support }\end{array}$ & FthrS & $\begin{array}{l}\text { Primarily a source of } \\
\text { financial support for } \\
\text { participants, but also } \\
\text { offered encouragement. }\end{array}$ & 3 & 20 & $15 \%$ \\
\hline
\end{tabular}


Mother Support. When participants were asked about the support they received from their family to attend college, the support of their mother was the most frequently mentioned $(n=18)$. In fact, $75 \%$ of participants $(n=24)$ whose mother was present in their lives mentioned her as a source of support regardless of whether or not they lived with their mother (Refer to Table 11). Participants indicated that their mothers provided them with emotional support.

I have days where you just get tired ... and you just don't want to do it anymore ... My mom is always there for me ... She tells me to keep going and that it will get better. She gives me advice and supports me in any way she can (Jessica C., 6/21/12, Question 6).

Participants also indicated that their mother was a source of encouragement and motivation.

My mom always tells me, échale muchas ganas, quiero que seas alguien importante, no quiero que estés como nosotros [keep it up, I want you to be someone important, I don't want you to be like us] and stuff like that. And when I'm stressed, she always tells me, you have to do good, primero tranquilizate y luego haces la tarea [first calm down and then you can do your homework], or go outside for a little bit para que te distraigas y después la vienes a hacer [for distraction and then you can finish it]. So she really motivates me (Jade, 9/20/12, Question 6). 
My mom always encourages me with what she says, like you're a really bright young man, you can do so many things, there are so many opportunities in this country, there's no reason for you not to succeed and things like that (Quetzalcoatl, 9/13/12, Question 6).

Mothers were also reported to be a source of financial support. In fact, some participants indicated having the ability to live at home without the financial pressures of paying rent. "I feel like my mom is really supporting me because she always tells me, you don't have to pay rent as long as you go to school ... you can help me later" (Jessica S., 9/12/12, Question 1). In other cases, participants mentioned their mothers assisting them with the purchase of school supplies. "If I need the money to buy a book ... or if I need paper, pencils or whatever it is, she'll somehow come up with the money or half of it to help me buy what I need" (Faith, 9/13/12, Question 6). Any financial support mothers provided was done with much sacrifice. "My mom contributes what little money she has ... even if that means having to work another month with uncomfortable wet boots" (Esperanza, 9/17/12, Question 6).

Finally, participants also reported that despite their mothers' low level of education, their strict attitude combined with assistance in taking care of participants' children while participants attended school was beneficial and made it easier.

Mi mamá siempre ha sido estricta o dura pero yo agradezco ... Yo me acuerdo que un día le dije no iba a ir a la escuela y así como estaba me llevó. Literalmente greñuda, en pantuflas agarro y me subió al carro y me dejó afuera 
de la secundaria. So dije, jamás lo vuelvo a hacer. Aparte, el hecho de que ella me cuida a mi hijo para que yo haga tarea o valla a la escuela me ayuda muchísimo. No sé si podría hacerla sin su ayuda. [My mom has always been strict and hard but I'm grateful ... I remember one day I told her that I wasn't going to school and she took me with my hair messed up, with slippers on, she put me in the car and left me outside the school. So I was like I'll never do that again. Besides, the fact that she watches my son so that I can do homework or go to school is very helpful. I don't know if I could make it without her help] (Yadira, 6/25/12, Question 6).

Overall, participants indicated that their mother demonstrated value and support for education by consistently (a) asking them about their classes, (b) dismissing them from doing household chores, (c) staying up late to keep them company during late night assignments, and (d) providing advice, encouragement, financial help, and babysitting assistance. Aside from receiving support from their mother to attend college, some participants also mentioned being supported by their husband.

Husband Support. Husband support was the second most frequently mentioned source of support for attending college $(n=6)($ Refer to Table 11). Although only six participants indicated the support of the husband as key to attending college, it is important to note that this number represents all of the participants $(\mathrm{n}=6,100 \%)$ who were married. All participants who were married indicated that they primarily received financial support from their husband so that they could attend college. 
Mi esposo me apoya económicamente porque yo no estoy trabajando ... me ayuda a comprar libros, con la gasolina ... con cualquier cosa que necesite para la escuela [My husband supports me financially because I'm not working. . . he helps me purchase books, with gas ... with anything I need for school] (Alejandra, 9/20/12, Question 6).

One participant indicated that her husband was willing to take on more work responsibilities so that she could make school her priority. "My husband works two jobs just so that I can be a full time student" (Starlette, 6/21/12, Question 6).

More than half of the participants who were married $(n=4,67 \%)$, indicated that their husband demonstrated his support by allowing them to attend college.

Mi esposo me apoya ... dándome permiso. Porque muchas familias Mexicanas son de que el hombre trabaja y la mamá se queda en casa... No le importa que no esté en la casa limpiando, cocinando, o trabajando. Porque sabe que estoy invirtiendo en mi para un mejor futuro para mí y para mi familia. [My husband supports me ... giving me permission. Because a lot of Mexican families are the type where the man works and the mom stays home ... He doesn't care if I'm not home cleaning, cooking, or working. Because he knows that I'm investing in me for a better future for our family] (Dulce, 9/18/12, Question 6). One participant indicated that she had to "prove herself," "batallar [struggle]", and "pelear [fight]," with her husband so that he would "allow" her to attend college. 
Al principio [mi esposo] se molestaba mucho si yo dejaba a los niños en un lado para poder ir a la escuela... había pleitos. Tuve que ir brincando todo eso para hacerlo entender que era para el propio beneficio de nuestra familia... Creo que cuando él más entendió que necesitaba apoyarme y dejarme ir a la escuela es cuando él vio que ya no necesitaba yo llevarle mis cartas o mis biles a la vecina para que me los tradujera... El miró que ya podía ayudarle hasta a él a leer los papeles o a hacer citas. [At first, it bothered [my husband] if I left our children some place so that I could go to school ... there were disputes. I had to overcome all of that to make him understand that it was for the benefit of our family ... I think that when he most understood that he needed to support me and allow me to go to school was when he saw that I no longer needed to take my letters and bills to our neighbor for translation. He saw that I was even able to help him read documents or make appointments] (Cristina, 6/28/12, Question 6).

Overall, for participants who were married, their husband was a major source of support in their pursuit for higher education. Similarly, participants also mentioned receiving support from their siblings to attend college.

Older Sibling Support. As demonstrated on Table 11, the third most frequently mentioned source of support for attending college was sibling support $(n=5)$. Although only five participants indicated receiving support from their siblings to attend 
college, this number represents $100 \%$ of participants who had older siblings. All participants who had older siblings indicated that their siblings provided them with encouragement, advice, financial support, and in some cases offered academic assistance. Sisters and brothers were perceived by participants as equally supportive of their education. In speaking about sisters, participants indicated, "My sister always encourages me to go to school and not to drop out" (Adela, 6/27/12, Question 6). "She has always helped me out with homework or encourages me by telling me I can do anything" (AJ, 7/2/12, Question 6). Similarly, in speaking about their brothers, participants mentioned, "My brother supports me financially like if I ever need anything for school" (Rob, 6/21/12, Question 6). "Every so often, one of my brothers sends me a gift card for Barnes and Noble to help me pay for my books" (Starlette, 6/21/12, Question 6). Aside from receiving the support of their siblings in their college pursuit, participants also mentioned the support of their extended family.

Extended Family Support. Extended family was mentioned by 15\% of participants $(\mathrm{n}=4)$ as a source of support in their college pursuit (Refer to Table 11). Members of the extended family included aunts, uncles, godparents, and grandparents. Participants indicated that although their extended family praised them and in some cases assisted them in taking care of their children (for participants who were parents), they were primarily a source of financial support. Participants mentioned, "My whole family always supports me any way they can, but it's mainly with money" (Lili, 6/29/12, Question 6). “If I ever need money for my classes or school, it isn't always my 
parents who help pay ... I can also ask my uncles, my aunts, or my godparents for money" (Ernesto, 9/24/12, Question 6). "I know I could count on anyone in my family . .. I know that hands down they would give me the money for any necessity I would need for school" (Rob, 6/21/12, Question 6). Similarly, some participants also mentioned the support of their father.

Father Support. Father support was the least frequently mentioned source of support for attending college ( $\mathrm{n}=3$ ) (Refer to Table 11). However, it is important to note that of the total study sample $(n=26), 77 \%$ of participants $(n=20)$ had a father present in their lives while $23 \%$ of participants $(\mathrm{n}=6$ ) came from a single-parent family where the mother was head of household. Of the participants who had their father present in their lives $(n=20), 15 \%$ of them $(n=3)$ primarily mentioned their father as a source of financial support. "My dad helps me as much as he can with anything financial like my books, with school, or if I need my phone bill to be paid" (Sophia, 9/24/12, Question 6). However, of the three participants who mentioned father support, one participant mentioned that his father also encouraged and motivated him to pursue higher education.

"I could hear my dad's voice clearer than my mom's. He always had the best consejos [advice] to give about everything. He's one of the main reasons why I feel capable of breaking any kind of habits or getting over anything. He would tell me to work hard and do good in school. He was primarily the one who encouraged me to go to school" (AJ, 7/2/12, Question 6). 
Although all participants in this study mentioned that their family was very supportive in their pursuit of a college education, most participants indicated that their family members, especially their parents, were unable to assist them with academic concerns as described in this next section.

\section{Barriers of La Familia [the Family] to Providing Academic Assistance and their Advice for Seeking Support of Key People.}

Question 7: Tell me about the support you receive from your family to deal with academic concerns.

None of the participants in this study mentioned their parents as a source of support for academic concerns. Participants mentioned two specific barriers that prevented their familia [family] from proving them with academic assistance and advice. These barriers included parents' (a) limited education and (b) overwhelming work responsibilities. Of the two barriers cited, parents' limited level of education was the most frequently cited obstacle to providing academic assistance (Refer to Table 12 below).

Table 12

Barriers of La Familia [the Family] to Providing Academic Support

\begin{tabular}{lclc}
\hline Category & Code & \multicolumn{1}{c}{ Code Definition } & $\begin{array}{c}\text { Number of } \\
\text { Responses* }\end{array}$ \\
\hline $\begin{array}{l}\text { Limited } \\
\text { Education }\end{array}$ & LmtEd & $\begin{array}{l}\text { Low educational level (less than a high school } \\
\text { diploma), not knowing the language, and not } \\
\text { understanding the educational system of the United } \\
\text { States. }\end{array}$ & $26(100 \%)$ \\
$\begin{array}{l}\text { Work } \\
\text { Responsibilities }\end{array}$ & WkRsp & $\begin{array}{l}\text { Having multiple jobs and/or working long hours with } \\
\text { limited flexibility. }\end{array}$ & $8(31 \%)$ \\
\hline${ }_{n}=26$ & & &
\end{tabular}


Parents' limited level of education. All study participants indicated that their parents were unable to assist them with academic concerns due to their limited level of education. Participants expressed that even if their parents wanted to help, they could not count on them for assistance because they had not finished school and would not have a clue on how to provide the needed support. Most participants indicated that their parents struggled with speaking and/or understanding English. Participants also indicated that since their parents had less than a high school education they knew more than their parents in terms of academics. Therefore, most participants responded similarly to one participant who stated needing to "rascarse con sus propias uñas" [fend for themselves] anytime they struggled academically.

I can't really count on anyone else in my household for homework assignments. My dad didn't even finish elementary school; he dropped out in the fifth grade to help his family financially. My mom went back to get her GED but she dropped out in $9^{\text {th }}$ grade. My brothers, they went to mechanic school so it's pretty much just me. I have to figure it out by myself (Starlette, $6 / 21 / 12$, Question 7).

Participants also mentioned that their parents lacked understanding about how the college system worked in comparison to the educational system they had experienced in their country. 
They really don't know how college works here. I believe that if we were in México they would know how the system works, but over here they don't have any idea of how college works, credits, units, all of that (Fred, 9/21/12, Question $6)$.

Thus, parents were often unable to assist with anything that was college related. "They don't know a lot of these things. They have no idea about financial aid or about college, how to get into college or do those things" (Sophia, 9/24/12, Question 7). Overall, participants mentioned that aside from coming from a household where their parents had a limited level of education, they also struggled with the fact that their parents had overwhelming work responsibilities that did not allow them to offer their support with academic concerns.

Parents' work responsibilities. Thirty-one percent of participants $(n=8)$ said that their parents were often unable to support them academically due to their hectic and inflexible work schedules (Refer to Table 12). "My mom had two or three jobs. Her not being there was hard ... when I used to get home from school there was like really no one that could teach me how to do anything, so I was basically on my own" (Yvonne, 9/26/12, Question 1). The fact that some parents had multiple jobs or were working all the time often left students feeling alone and neglected. "My mom would get home tired to cook, clean that she didn't really acknowledge or ask too much about school" (Anahi, 9/25/12, Question 1). "I felt like there wasn't that much love because my 
parents were in such a struggle that they couldn't really focus on the kids because they were trying to focus on providing so much for us" (Faith, 9/13/12, Question 5).

Given their limited level of education and work responsibilities, parents struggled to provide their children with the necessary guidance and advice they needed to navigate the system of higher education and often had to rely on the support of key people outside their familia [family].

\section{Parents' advice for seeking support of key people outside la familia [the}

family]. All participants in this study $(n=26,100 \%)$, indicated that since their parents were not able to provide them with the necessary guidance to attend college, their parents often advised them to seek the support of key people on the college campus that could possibly assist them with their college-related questions and concerns.

Whenever I have any problems, my parents normally tell me to find help in the college ... My mom just tells me to ask my professor or anyone in the college who will explain things and who will help me try to come up with a solution (Quetzalcoatl, 9/13/12, Question 7).

Through their parents' direction, $100 \%$ of participants $(n=26)$ indicated that anytime they experienced difficulties, they would see a college instructor, a friend, and/or or a college counselor. Of these individuals, participants specifically emphasized counselors as a very important support service in community college campuses to guide and assist them with their concerns. One participant indicated, "There's teachers that you can go to, but they really don't know like counseling wise. 
So counselors are more important to tell you about classes, or how to transfer, or how to not overwhelm yourself with classes" (Yvonne, 9/26/12, Question 9). The following section describes participants' perceptions about the importance of community college counseling services.

\section{The Importance of Community College Counseling in Supporting Students} Question 9: How would you describe the importance of counseling in community colleges?

Participants considered counseling services to be an important support service on community college campuses. In fact, $96 \%$ of students $(n=25)$ described counseling services as "very important" or "important," while only one student described counseling as "not important" (Refer to Table 13 below).

Table 13 Importance of Community College Counseling Services

\begin{tabular}{cc}
\hline Importance & Number of Responses* \\
\hline Very Important & $17(65 \%)$ \\
Important & $8(31 \%)$ \\
Not Important & $1(4 \%)$ \\
\hline${ }^{*} \mathrm{n}=26$ &
\end{tabular}

Most participants indicated that counseling services were especially important for firstgeneration students who typically (a) feel lost and confused, (b) need step-by-step guidance, (c) want encouragement, and (d) cannot rely on their parents for assistance. "I think counseling is way more important for first-generation students because you have no idea of what to expect." (Fred, 9/21/12, Question 9) "You know, when you're new you need to know where to go, what to do, what to expect, you're just like huh?" (Marisol, 9/15/12, Question 15) "You really don't hear it from your parents where they 
tell you what you need to do or where to go, so counseling is extremely important in getting your foot in the door of college" (Esperanza, 9/17/12, Question 9).

Participants also mentioned that counseling was important in order to verify that they understood the steps they needed to take to ensure that they are on the right path.

I always have to see a counselor to help me and understand more what I need to do or what path to take. I just don't want to do things wrong. And then I can't ask my mom or my dad (Jade, 9/20/12, Question 9).

In fact, some participants indicated the need to solicit information from counselors multiple times in order to be able to fully comprehend the subject of discussion.

I feel like me coming from a family that hasn't been to college, this is so new to me so I need to like hear it three times to like get it into my head so that I can be like oh ok I know what you mean (Jessica S., 9/12/12, Question 9).

Finally participants indicated the importance of counseling in assisting them in completing their goals and reaching success.

Counseling is extremely important in any college because you're handling someone's life. Education is the pathway to success, and that success can depend on whether the counselor is giving students adequate information to where they can apply themselves to the position they want to be in or the places where they want to go (Question 9). In a sense counselors are like a guide 
through a valley where there's many dreams and many pitfalls. . . and without a counselor you're kind of stuck on your own (Alexzander, 9/20/12, Question 10).

As indicated on Table 13 above, although the majority of participants $(n=25,96 \%)$ believed that counseling services were important or very important, there was one participant who felt that counseling was not important. However, she confirmed that her feeling about the lack of importance of counseling had to do with her limited exposure to counseling services.

I feel like counseling is not important . . . I guess if I utilized it better it would be ok ... I'm not really aware of how well the counseling system works because I don't really immerse myself in it (Genesis, 6/21/12, Question 9).

Overall, participants expressed that community college counseling services were crucial for them to be able to (a) receive individualized and step-by-step guidance, (b) obtain support and encouragement, (c) solicit and verify information, and (d) gain the motivation, confidence, and tools needed to complete their educational objectives. Participants also shared their perspectives about the role of community college counseling services as described in the next section.

\section{Students' Perceptions about the Role of Community College Counselors} Question 10: Based on your experience, how would you describe the role of counselors?

The two counselor roles that participants most frequently mentioned for community college counselors were guiding and helping. All participants $(n=26$, 
$100 \%)$ indicated that a counselor's role was to guide, while half of them $(n=13,50 \%)$ indicated that their role was to help (Refer to Table 14 below). The terms guide and help are very close in definition and could have been collapsed into one category. However, these terms were separated based on what the researcher gathered from participants' responses in regards to the role of a community college counselor. As demonstrated on Table 14, when participants spoke about counselors' ability to guide, they mostly referred to academic concerns. On the other hand, when participants spoke about counselors' ability to help, they seemed to indicate mostly personal concerns and to a smaller degree the things related to educational planning.

Table 14

Role of Community College Counselors

\begin{tabular}{lclc}
\hline Category & Code & Code Definition & $\begin{array}{c}\text { Number of } \\
\text { Responses* }\end{array}$ \\
\hline Guide & Gd & $\begin{array}{l}\text { Guide students in the educational path they desire, show } \\
\text { them the courses that are required for their path, make } \\
\text { recommendations and/or give advice on courses to take. }\end{array}$ & $26(100 \%)$ \\
Help & Hlp & $\begin{array}{l}\text { Help students with personal problems, the development of } \\
\text { an educational plan, and anything they need to succeed } \\
\text { (resources, motivation, follow-up) }\end{array}$ & $13(50 \%)$ \\
\hline${ }^{*} \mathrm{n}=26$ & &
\end{tabular}

As shown on Table 14, participants defined a community college counselor's role by their ability to: (a) guide them in the right path, (b) ensure that they are taking the right courses, (c) give advice on what courses to take, (d) discuss options, (e) develop an educational plan that meets their career goal, and (f) help if they are struggling academically and/or personally. Some participants gave metaphorical definitions to illustrate the role of counselors. 
Counselors metaphorically are those people that kind of open the door to a library and show you what books to read, what classes you need to take, what's beneficial to you in terms of not wasting your time and your money ... They're really important and a good tool to use if you find a counselor that suits you and understands your needs. I think they're here for personal and academic assistance (Esperanza, 9/17/12, Question 10).

Overwhelmingly, participants felt that it was a counselor's role to assist them with whatever is in their power and help them graduate no matter what. Aside from commenting on the counselor's role, participants also mentioned characteristics that they believed were important for a counselor to possess.

Characteristics of Un Buen Consejero [a Good Counselor] in Community College Question 11: If you were to describe a perfect counselor, what would he/she be like?

Participants indicated that un buen consejero [a good counselor] was one who was (a) caring, (b) able to guide them in the right direction, (c) welcoming, (d) interested, (e) knowledgeable, (f) helpful, (g) bilingual, and (h) available. (Refer to Table 15 below). 
Table 15

Characteristics of Un Buen Consejero [a Good Counselor] in Community College

\begin{tabular}{|c|c|c|c|}
\hline Category & Code & Code Definition & $\begin{array}{l}\text { Number of } \\
\text { Responses* }\end{array}$ \\
\hline Caring & $\mathrm{Crg}$ & $\begin{array}{l}\text { Takes time, listens to concerns, focused on the } \\
\text { individual, builds connections, makes individuals feel } \\
\text { comfortable, and is patient, encouraging, } \\
\text { understanding, trustworthy, respectful, and } \\
\text { supportive. }\end{array}$ & $26(100 \%)$ \\
\hline Guide & Gd & $\begin{array}{l}\text { Guide students in the educational path they desire, } \\
\text { show them the courses that are required for their path, } \\
\text { make recommendations and/or give advice on courses } \\
\text { to take. }\end{array}$ & $26(100 \%)$ \\
\hline Welcoming & Welc & $\begin{array}{l}\text { Friendly, approachable, easy to talk to, open, } \\
\text { outgoing, funny, makes you feel comfortable. }\end{array}$ & $26(100 \%)$ \\
\hline Interested & Intr & $\begin{array}{l}\text { Showing interest in others' personal and academic } \\
\text { welfare, by (a) following-up via email and/or phone } \\
\text { and (b) encouraging multiple visits. }\end{array}$ & $22(85 \%)$ \\
\hline Knowledgeable & Knowl & $\begin{array}{l}\text { Knows answers to questions posed and/or is willing to } \\
\text { find them. }\end{array}$ & $13(50 \%)$ \\
\hline Helpful & Hlp & $\begin{array}{l}\text { Help students with personal problems, the } \\
\text { development of an educational plan, and anything } \\
\text { they need to succeed (resources, motivation, set } \\
\text { realistic goals, apply to universities, apply for } \\
\text { scholarships) }\end{array}$ & $13(50 \%)$ \\
\hline Bilingual & Bilngl & $\begin{array}{l}\text { Has the ability communicate with others fluently in } \\
\text { English and Spanish. }\end{array}$ & $10(38 \%)$ \\
\hline Available & Avail & $\begin{array}{l}\text { Can easily contact and/or schedule appointments with } \\
\text { a counselor. }\end{array}$ & $8(31 \%)$ \\
\hline
\end{tabular}

Care for, guide, and welcome students. As demonstrated in Table 15 above, $100 \%$ of participants $(\mathrm{n}=26)$ agreed that community college counselors had to be caring, welcoming, and possess the ability to guide students in the right direction.

When it comes to a good counselor, I think it's someone that knows you, knows your background ... and don't just treat you like any other student. Kind of like 
your friend but in a professional manner where ... they help you out with your classes, they push you, and make you feel welcome (Anahi, 9/25/12, Question 11).

A perfect counselor would be someone that I can go to and talk to about anything, from my classes to stresses at home and school. I want them to be able to have suggestions or advice. Because I feel that that's what they should be there for (Sophia, 9/24/12, Question 11).

In some cases, participants indicated they wished that their counselor was like other faculty they had encountered on the college campus.

Counselors should probably be like my creative writing teacher ... very open . . . just a loving and caring person who's dealt with things themselves and who can understand you and guide you in the direction you want to go toward (AJ, 7/2/12, Question 11).

Overall, participants wanted counselors who "are just really supportive . . motivating, caring, and want to see you succeed" (Faith, 9/13/12, Question 11). Participants also mentioned that they wanted counselors to demonstrate interest in students.

Demonstrate interest in students. More than half of participants $(n=22,85 \%)$ felt that counselors had to show interest in their personal and academic welfare (Refer to Table 15). "A perfect counselor would be someone that will actually do a follow up on you, ask you to come back and set up another appointment with them, and has the interest in talking to you" (Rob, 6/21/12, Question 11). 
Un buen consejero debe de estar al pendiente del estudiante de cómo va en sus estudios, sus calificaciones, y de cómo se siente con la escuela. Debe de ofrecer ayuda. . . Por ejemplo, si el estudiante tiene un problema psicológico o algún problema familiar, que le ofrezca esa ayuda. Debe de apoyar al estudiante y hacerle encourage a seguir con los estudios. [A good counselor should keep an eye on students on how their classes are going, their grades, and how they're feeling in school. They should offer them assistance ... For example, if they have a psychological or family problem, that they offer them assistance. They should support students and encourage them to continue with their studies] (Mario, 6/26/12, Question 11). El consejero debe de pensar un poquito en las necesidades especiales de cada estudiante como persona individual y las opciones que tiene. [The counselor should think about the special needs of each student as an individual person and about the options they have] (Cristina 6/28/12, Question 11).

In addition, participants felt that counselors needed to be knowledgeable and helpful.

Knowledgeable and helpful to students. Half of the participants $(n=13,50 \%)$ mentioned that a perfect counselor had to be knowledgeable and helpful (Refer to Table 15). "A counselor has to be knowledgeable in the different fields that are out there and the different career paths one can take" (Jessica C., 6/21/12, Question 11). "If they don't have the answer they should ask for it" (Adela, 6/27/12, Question 11). "I think more than anything counselors should be qualified and know what they're talking about 
because they're dealing with students and their future" (Esperanza, 9/17/12, Question 11). Finally, participants indicated that counselors should offer bilingual services and be available.

Bilingual and available. Less than half of participants indicated that un buen consejero [a good counselor] should be bilingual $(n=10,38 \%)$ and available $(n=8,31 \%)$ (Refer to Table 15).

En mi caso como inglés es mi segundo idioma, pues un buen consejero sería que hable español para que nos podamos entender mejor. Que te ayude, te explique las cosas paso por paso... te de información sobre los programas o los servicios que uno puede agarrar, que se interese en ti, que esté disponible cuando lo necesites, y que sea paciente. Que pongan empeño en que te superes y que te motiven a que no te des por vencido. [In my case since English is my second language, a good counselor should speak Spanish so that we can better understand each other. They should help you, explain things step-by-step ... give you information about the programs or services that we can get, show interest in you, be available when you need him, and be patient. They should make the effort to motivate you to succeed and not give up] (Alejandra, 9/20/12, Question 11).

Overall, participants expressed that los buenos consjeros [good counselors] needed to be (a) caring, (b) welcoming, (c) interested, (d) knowledgeable, (e) helpful, (f) bilingual, 
(g) available, and (h) able to guide students in the right direction. In general, participants whose counselors possessed these characteristics were more likely to describe their counseling experience as positive compared to participants whose counselor did not possess such characteristics as described in the next section.

\section{Students' Positive Community College Counseling Experiences}

Question 12: Describe positive counseling experiences you have had with community college counselors and what you liked about those experiences.

Question 15: How does your counselor maintain contact with you during the semester or inform you about important deadlines, scholarships, financial aid etc.?

Question 16: What are the ways in which your counselor shows a genuine interest and care in your personal and academic success?

Question 17: How has your counselor motivated you to stay in college?

Positive community college counseling experiences were related to counselors possessing the characteristics of un buen consejero [a good counselor] Los buenos consejeros [the good counselors] were those who were (a) caring, (b) welcoming, (c) interested, (d) knowledgeable, (e) helpful, (f) bilingual, (g) available, and (h) able to guide them in the right direction (Refer to Table 15). Of the participants who indicated having positive experiences with counselors, more than half $(n=17,65 \%)$ indicated that this experience had to do with their counselor being caring, interested in their personal and academic welfare $(n=16,62 \%)$, and being willing to help them with anything necessary $(n=15,58 \%)$ and teach them about important websites and resources available for their use ( $\mathrm{n}=12,46 \%)$ (Refer to Table 16 below). 
Table 16

Positive Community College Counseling Experiences

\begin{tabular}{|c|c|c|c|}
\hline Category & Code & Code Definition & $\begin{array}{l}\text { Number of } \\
\text { Responses* }\end{array}$ \\
\hline Caring & $\mathrm{Crg}$ & $\begin{array}{l}\text { Takes time, listens to concerns, focused on the individual, } \\
\text { builds connections, makes individuals feel comfortable, } \\
\text { and is patient, encouraging, understanding, trustworthy, } \\
\text { and supportive. }\end{array}$ & $17(65 \%)$ \\
\hline Interested & Intr & $\begin{array}{l}\text { Showing interest in others' personal and academic } \\
\text { welfare, by (a) following-up via email and/or phone and } \\
\text { (b) encouraging multiple visits. }\end{array}$ & $16(62 \%)$ \\
\hline Help & Hlp & $\begin{array}{l}\text { Help students with personal problems, the development } \\
\text { of an educational plan, and anything they need to succeed } \\
\text { (resources, motivation, set realistic goals, apply to } \\
\text { universities, apply for scholarships). }\end{array}$ & $15(58 \%)$ \\
\hline Teach & Tch & $\begin{array}{l}\text { Teach students about programs and websites they can use } \\
\text { as a resource (assist, CSU mentor, financial aid etc). }\end{array}$ & $12(46 \%)$ \\
\hline
\end{tabular}

Out of the total study sample $(n=26)$, over two-thirds of participants $(n=18$, $69 \%$ ) expressed that they had a positive experience with their community college counselor. Of the 18 participants who indicated having a positive experience, $56 \%$ were part of categorical support programs (e.g., EOPS, MESA, Puente, and TRIO) $(n=10)$ while $44 \%$ were not part of any special population program $(n=8)$. The majority of participants in categorical support programs $(n=10,91 \%)$ indicated having a positive counseling experience with their community college counselor compared to slightly over half of participants $(n=8,53 \%)$ who were not part of any programs (Refer to Table 17 below). Students who were part of support programs were more likely than students who were not part of any programs to perceive their counseling experience as positive. 
Table 17

Participants' Community College Counseling Experiences

\begin{tabular}{cccc}
\hline Experience & $\begin{array}{c}\text { In Support Program } \\
(\mathbf{n}=\mathbf{1 1})\end{array}$ & $\begin{array}{c}\text { No Support Program } \\
(\mathbf{n = 1 5 )}\end{array}$ & $\begin{array}{c}\text { Total Number of Responses } \\
(\mathbf{n}=\mathbf{2 6})\end{array}$ \\
\hline Positive & $10(91 \%)$ & $8(53 \%)$ & $18(69 \%)$ \\
Negative & $1(9 \%)$ & $15(100 \%)$ & $16(62 \%)$ \\
\hline
\end{tabular}

All categorical participants who had a positive counseling experience $(n=18$, $100 \%$ ) described their counselor as caring, interested in their personal and academic welfare, willing to help them with anything necessary, and willing to teach them about important websites and resources available for their use (Refer to Table 18 below).

Table 18

Participants' Positive Community College Counseling Experiences in Support Programs vs No Support Programs

\begin{tabular}{cccc}
\hline Experience & $\begin{array}{c}\text { In Support Program } \\
(\mathbf{n}=\mathbf{1 0})\end{array}$ & $\begin{array}{c}\text { No Support Program } \\
(\mathbf{n}=\mathbf{8})\end{array}$ & $\begin{array}{c}\text { Total } \\
(\mathbf{n}=\mathbf{1 8})\end{array}$ \\
\hline Caring & $10(100 \%)$ & $8(100 \%)$ & $18(100 \%)$ \\
Interested & $10(100 \%)$ & $6(75 \%)$ & $16(89 \%)$ \\
Help & $10(100 \%)$ & $4(50 \%)$ & $14(78 \%)$ \\
Teach & $10(100 \%)$ & $3(38 \%)$ & $13(72 \%)$ \\
\hline
\end{tabular}

The positive counseling experiences that participants in categorical support programs described were in reference to their assigned program counselor, while the positive counseling experiences described by participants who were not part of special support program highlighted four counselors in particular. Thus, this section will be divided into two parts. The first part will review the positive community college counseling experiences with categorical counselors expressed by participants in support programs, while the second part will review the positive counseling experiences with their general counselors expressed by participants who were not part of any special support program. Categorical counselors are those who provide counseling services to students in 
programs such as EOPS, MESA, Puente, or TRIO. General counselors are those who provide counseling services for the general community college population.

Positive counseling experiences with categorical counselors. Participants in categorical support programs overwhelmingly expressed high satisfaction with their program counselor $(\mathrm{n}=10,91 \%)$ and described their counseling experience as more positive and different from their counseling experience prior to being part of the support program they were currently a part of.

It's different being part of programs like TRIO and MESA where you feel more of a comfort because you can come in and actually talk to your counselor. Instead of when you see a counselor up there in general counseling, there's no connection. Here, there's trust (Rob, 6/21/12, Question 9). En EOPS es diferente porque son más amables. Son como una familia . . más cercanos a los estudiantes. Como allá en consejería general, son un caso más o un número más y aquí son más humanos. Me gusta más aquí en EOPS porque se interesan más en ti. [In EOPS it's different because they are friendlier. They are like a family ... closer to students. Like over there in general counseling they are just another case or one more number and there they are more humane. I like it better here in EOPS because they are interested in you] (Dulce, 9/18/12, Question 19). 
It's different here in TRIO because I have my own counselor and that I don't have to look for different counselors all the time. When my counselor sees me, it's like she knows me. You know, like a person, not just like I'm a G number or something (Adela, 6/27/12, Question 12).

Participants especially emphasized the (a) caring encounters they experienced with their counselor, (b) interest their counselor demonstrated in their personal and academic success, and (c) desire of their counselor to help and teach.

Caring encounters. Participants defined a caring counselor as one who takes their time, listens to concerns, focuses on the individual, builds connections, makes individuals feel comfortable, and is patient, encouraging, understanding, trustworthy, and supportive (Refer to Table 16). As demonstrated in Table 18, all participants in categorical programs that indicated having a positive counseling experience $(\mathrm{n}=10$, $100 \%$ ), emphasized the caring encounters they experienced with their program counselor. Participants who were part of Puente $(\mathrm{n}=2,100 \%)$, described their counselor as a mom who could not be avoided in any way and who demonstrated that she cared about them by constantly contacting them and making herself available for anything they needed.

My Puente counselor, she's like another mom to us. In the beginning I was like 'Oh my God, she's so annoying, but she helps us and she's always there for us. She gives us her house phone, cell phone, everything. It's funny because she tells you, if you guys go out to a party and you guys need to have someone pick 
you up in the middle of the night, I'll pick you up. So she's super cool. She really cares (Lili, 6/29/12, Question 10).

Similarly, most participants who were part of EOPS $(n=5,83 \%)$, indicated that they were highly satisfied with their counselor and that they "could not ask for more" than what the program was already offering them. They especially emphasized "being treated like family."

I couldn't ask anymore than what EOPS does for us. My counselor is there for me listening to me and being patient and understanding. She's always there to advise me. She's nice, knowledgeable, listens to what I have to say and is respectful of my choices if I switch my ed plan. She takes her time (Jessica C., 6/21/12, Question 11).

I'm grateful for EOPS because these programs help us with so much in helping us move forward and really keeping us motivated to keep doing good. It really helps to get help with counseling, registration, and with anything we need (Ernesto, 9/24/12, Question 19).

In EOPS, they support us in every way (Question 10) ... You're like a little family ... they show us that they care and they give us the encouragement to keep going (Question 18) ... My counselor is always there for me. She always motivates me and knows that I get can get through anything and everything, she makes sure I'm on the right track ... She's great (Faith, 913/12, Question 11). 
Likewise, participants in TRIO $(n=3,100 \%)$ and MESA $(n=1,100 \%)$ indicated building a close relationship with their program counselor and feeling motivated to pursue their goals because of their counselor's assistance. "In TRIO and MESA, I like that you build a trust relationship and that they'll check up on grades and stuff like that . .. they expect something from you in a way" (Rob, 6/21/12, Question 12). "It's motivating to know that you can come and see everyone in TRIO happy that you're here. You're motivated to stay here because they care and are concerned about you and your success" (Adela, 6/27/12, Question 17). Participants in categorical programs also mentioned that the positive experiences they encountered with their counselor had to do with their counselor's ability to demonstrate interest.

Demonstrating interest. Participants defined an interested counselor as one who shows interest in others' personal and academic welfare, encourages multiple visits, follows-up, informs, and communicates via email/phone (Refer to Table 16). All participants in categorical support programs that indicated having a positive counseling experience $(n=10,100 \%)$, believed that their counselor showed interest in them and that this motivated them to continue pursuing their goals (Refer to Table 18).

Participants indicated that their program counselor always demonstrated an interest in their personal lives and their well-being. They believed that this was important as their personal lives also affected school and vice versa.

My counselor always asks me how I am or how my family is doing before anything. And then she goes on by saying how work is, how I'm paying for 
school, and is just a person with an open mind. She just wants to hear that you're fine and if you're not, then she'll help you (Question 16) ... My counselor is very friendly and always takes the time to say hi even outside her office ... she won't try to ignore you or run away when you say hi like other counselors do (Quetzalcoatl, 9/13/12, Question 19).

My counselor is always welcoming when I come in. She always asks if there's anything good or bad or how everything is going. If there's something bad, she'll guide me or give me advice or tell me about tutoring if I'm struggling with a class. She's just interested in how I am (Anahi, 9/25/12, Question 16). Participants also mentioned that their program counselor demonstrated an interest in them by following-up and communicating with them on an ongoing basis.

One of the things I really like about my counselor is that she is always on top of us making sure we were doing good in our classes. She will check our grades, and then she will email us and tell us to not forget that we have a counseling appointment (Emily, 6/27/12, Question 10).

I really like that counselors show their interest in us by keeping us informed. With EOPS it's emails or letters in the mail about anything coming up or important deadlines. Puente, she'll like hunt you down. It's email, cell phone, house phone and she would talk to other Puente students. She'll get a hold of you somehow in some way. She's like ON US for everything. Like if she keeps 
in contact with us and is always reminding us, then we're not gonna give up (Lili, 6/29/12, Question 12).

For many participants, a counselor's willingness to stay in touch through follow-up made them believe that their counselor genuinely cared about them and their success. "The fact that my counselor keeps in touch makes me think that she not only wants me to succeed in college but in life" (Fred, 9/21/12, Question 16). "Following up and talking to you shows you that counselors do care and that they're interested in your success" (Rob, 6/21/12, Question 16).

Finally, participants in categorical support programs related their positive community college counseling experience to their counselor's desire to help and teach.

Helping and teaching. Participants defined a helpful counselor as one who was able to help students with personal problems, academic concerns, and/or anything necessary for their success (e.g., resources, motivation, realistic goal-setting, university and scholarship applications). They indicated that helpful counselors were also often willing to teach students about programs and websites that could serve as a resource (e.g., assist. CSU mentor, financial aid, etc.) (Refer to Table 16). All participants in categorical support programs who had a positive counseling experience $(n=10,100 \%)$ indicated that their program counselor was always willing to help them with anything they needed and taught them about various resources they could use (Refer to Table $18)$. 
My counselor helps me a lot. She taught me the assist website, how to look for what classes I need to take here to transfer to San Jose State, and she helped me do my ed plan. She showed me how to use the catalog, and a lot of stuff that I think the student needs to know when they're coming to a community college especially if they have parents who can't really help them with all that stuff (Emily, 6/27/12, Question 9).

Interestingly, a few of the participants who were part of categorical support programs $(n=4,36 \%)$ indicated that they often became a resource and a source of assistance for other students on campus who were not part of any programs. "What I've learned from my counselor, I've been able to help out my friends. Everything they've taught me about assist and other programs I've been able to pass it on to other people and help them" (Rob, 6/21/12, Question 12).

According to participants in categorical support programs, counselors' willingness to care, show interest, help, and teach instilled confidence in them to complete their educational objectives.

My Puente counselor has always told us that we can do anything but that it's up to us. She always says 'más ganas' or something like that. So her helping us is like a little nudge to continue moving forward. That really motivates me (Lili, 6/29/12, Question 17). 
My counselor in EOPS kind of assures me that I'm gonna make it. She tells me oh I know you can do it, I know you'll get your class done, I know you'll pass it, you're smart you can do it, I can't wait for you to be a nurse you're gonna get into the nursing program soon you'll be great. Just very encouraging statements that keep me working hard to get where I want to go in life (Faith, 9/13/12, Question 17).

Overall, most participants who were part of categorical support programs $(n=10$, 91\%) indicated that everything about their experiences with their program counselor had been positive. However, there was one participant in EOPS who indicated a contrary experience from the majority of participants in categorical support programs.

My counselor doesn't really acknowledge how I'm feeling. We just do what we have to do with my ed plan and she sends me off on my way (Question 11). Also, I've tried to meet with my counselor more than three times but when I've called to make the appointment there was a lot of questioning like why did I want to see her. So, it made me feel bad and I was like never mind I don't need the appointment. Then when I finally met with my counselor, she was like what did you want to see me for? You've already completed your three contacts, so what can I help you with? The fact that she told me I had made my three contacts made me feel like I couldn't come back once I had met with her those three times. That's why I don't go to my counselor besides the three required times (Question 8). I have a fear now of when I want to talk to my counselor. I 
don't want to call and set up an appointment because I'll get questioned. It's kind of like the doctor's office, what do you need to be seen for? That's what the doctor is for and in this case that's what the counselor is for so I can tell them what's going on. I may just want to go and say hi and that should be ok (Starlette, 6/21/12, Question 14).

Starlette was the only participant from a categorical support program that indicated having a negative counseling experience with her program counselor. All other participants who were in categorical support programs $(n=10,91 \%)$ indicated a positive counseling experience with their program counselor. Similarly, participants who were not part of any categorical support programs also indicated having positive community college counseling experiences with some of the counselors with whom they met.

Positive counseling experiences with general counselors. Of the total study sample ( $\mathrm{n}=26$ ), only $31 \%$ of participants $(\mathrm{n}=8)$ described a positive counseling experience with a general counselor. However, of the participants who were not part of support programs $(\mathrm{n}=15)$, slightly over half $(\mathrm{n}=8,53 \%)$ indicated having positive experiences with their community college counselor (Refer to Table 17). Similar to participants who were part of categorical programs, those who were not part of a support program and who indicated having a positive counseling experience $(n=8,53 \%)$ also described their counselor as caring $(n=8,100 \%)$, interested in their personal and academic welfare $(n=6,75 \%)$, willing to help them with anything necessary $(n=4,50 \%)$ 
and teach them about important websites and resources available for their use $(n=3$, $38 \%$ ) (Refer to Table 18).

The positive community college counseling experiences expressed by participants who were not part of a support program highlighted four specific counselors at El Toro Community College District (ETCCD). Of the four counselors mentioned by participants, only two were general counselors, while the other two were categorical counselors who also serve the campus in the role of general counselors. There are 13 general counselors at ETCCD and nine categorical counselors. Of the nine categorical counselors, two are general counselors for part of their work load and both of these counselors were mentioned in participants' positive counseling experiences. This unsolicited data seems to support the fact that participants indeed feel supported by counselors from categorical programs. Table 19 below demonstrates the four counselors highlighted. Counselors were labeled as categorical and general to protect their identities.

Table 19

Participants' Positive Community College Counseling Experiences with General Counselors

\begin{tabular}{cc}
\hline Counselor & Number of Responses* \\
\hline General Counselor (Male) & $4(50 \%)$ \\
Categorical Counselor 1 & $3(38 \%)$ \\
General Counselor (Female) & $2(25 \%)$ \\
Categorical Counselor 2 & $2(25 \%)$ \\
\hline${ }^{*} \mathrm{n}=8$ &
\end{tabular}

Participants felt that their counselor cared about their success because they (a) were welcoming, (b) took their time and explained everything step-by-step, (c) 
developed an educational plan that indicated an end goal (certificate/degree/transfer), and (d) provided support and encouragement. In fact, two participants indicated that they visited several counselors until they finally found a counselor they liked and who met their individual needs.

El consejero que tengo ahorita. . él si me gusta y con él me quedé. El es muy accesible. Vas a la cita y no te está explicando todo rápido. Te da tu tiempo a que pienses en lo que te está diciendo. Son muy contados los consejeros que son pacientes con los estudiantes pero él es uno de ellos (Question 12). También me motiva. Cuando me quejo de mis clases él me dice, no te des por vencida, todo se puede hacer siempre y cuando tú quieras. Y pues eso me demuestra que él quiere que yo salga adelante. [The counselor that I have right now is a Latino and I like him, so I stayed with him. He is very accessible. You go to the appointment and he is not explaining things in a hurry. He gives you time to think about what he's saying. There are very few counselors who are patient with students, but he is one of them. He also motivates me. When I complain about my classes he tells me, don't give up, anything can be done as long as you want to. So that shows me that he wants me to succeed] (Alejandra, 9/20/12, Question 16).

Participants also indicated that their counselor cared about their success in college because they (a) were friendly, (b) welcoming, (c) treated them like family, and (d) took their time in explaining things step-by-step. 
Me gusta mucho como ella me ayuda porque habla español, es amable, me explica cuales son las clases que tengo que tomar y cuáles van a ser mis clases después. Porque yo soy una de esas personas que yo sola no entiendo mucho. Aunque yo lea algo, necesito que me expliquen paso por paso para yo entender. Y ella es así. Y no nada más me dice ten has esto. Tiene el interés de tomarse su tiempo solo para mí, como si fuera de su familia. [I really like how she helps me because she speaks Spanish, is friendly, explains what classes I have to take now and which classes I'm going to take later. Because I'm one of those people who doesn't understand things on my own. Even if I read something, I need someone to explain things step by step so that I can understand. And she's like that. She doesn't just say here do this. She is interested in taking her time just for me, like I'm part of her family] (Jade, 9/20/12, Question 12).

Participants also emphasized counselors' interest in their personal and academic welfare.

A counselor I met with . . . actually got a little more personal with me and she would remember what was my background and what I had told her in my last meeting. She asked me about my goals and planned my ed plan and classes around my life because at that time I was trying to get a job. She was just interested in me. (Yvonne, 9/26/12, Question 12) 
Participants also highlighted counselors' (a) ongoing follow-up, (b) encouragement of multiple counseling visits, and (c) high degree of knowledge, and (d) support.

I've only had one positive experience with a counselor, so I've continued to meet with her. What I liked about her was that she listened to what I needed, looked up on her computer what would be beneficial for me, gave me feedback and asked me if I had any concerns. She was open to that idea of not just having that one counseling session and that was it. But she said if I had any more questions I could come back to her, email her, or call. She made herself available if I needed more help. And even when I don't make an appointment with her, she emails me things or makes little notes so the next time I return she tells me this is beneficial for you or I have this for you. I don't have to ask her. She cares and looks prepared, qualified, and knows what she's doing (Question 12). She pushes me and gives me the confidence to move forward by telling me good job, keep it up, or you'll have no problem transferring (Esperanza, 9/17/12, Question 17).

Overall, similar to participants who were part of categorical support programs, the positive counseling experiences described by participants who were not part of support programs highlighted four specific general counselors who possessed the characteristics of un buen consejero [a good counselor]. Buenos consejeros [good counselors] as described by participants were those who were (a) caring, (b) welcoming, 
(c) interested, (d) knowledgeable, (e) helpful, (f) bilingual, (g) available, and (h) able to guide them in the right direction (Refer to Table 15).

Although more than half of participants $(n=18,69 \%)$ in the total sample described positive community college counseling experiences, negative counseling experiences were expressed by $100 \%$ of participants $(n=26)$ as described in the next section.

\section{Students' Negative Community College Counseling Experiences}

Question 13: Describe negative counseling experiences you have had with community college counselors and what you disliked about those experiences.

All participants in this study indicated having a negative community college counseling experience. Participants' negative counseling experiences were primarily in reference to general counselors. In fact, of the total study sample $(n=26)$ only one participant (Starlette) indicated having a negative experience with her categorical program counselor compared to $100 \%$ of participants who indicated a negative counseling experience with a general counselor (Refer to Table 20 below).

Table 20

Number of Participants who had at Least One Negative Counseling Experience with Categorical Counselors and General Counselors

\begin{tabular}{cc}
\hline Counselor & Number of Responses* \\
\hline Categorical Counselor & $1(4 \%)$ \\
General Counselor & $26(100 \%)$ \\
\hline${ }^{*} n=26$ &
\end{tabular}

Participants' negative community college counseling experiences were based on the perception that their counselor (a) lacked caring, (b) rushed them during counseling 
appointments, (c) provided them with no options and threw them into classes, (d) discouraged them from pursuing their goals, (e) was unavailable, and (f) gave them conflicting information (Refer to Table 21 below).

Table 21

Negative Community College Counseling Experiences

\begin{tabular}{|c|c|c|c|}
\hline Category & Code & Code Definition & Number of Responses* \\
\hline No Caring & $\mathrm{NCrg}$ & $\begin{array}{l}\text { Not interested in student. Get the "job" done } \\
\text { without taking the time to get to know the } \\
\text { individual or ask about their personal life and/or } \\
\text { goals. Do not encourage them to come back. }\end{array}$ & $24(92 \%)$ \\
\hline Rushed & Rsh & $\begin{array}{l}\text { Appointments and conversations are "fast" and in a } \\
\text { hurry. }\end{array}$ & $20(77 \%)$ \\
\hline No Options & NOpt & $\begin{array}{l}\text { No discussion about educational options (courses, } \\
\text { universities, degrees). "Throws" individuals into } \\
\text { classes without providing options or explanations } \\
\text { on course content. }\end{array}$ & $18(69 \%)$ \\
\hline Discourage & Dscrg & Discourage students from pursuing their goals. & $13(50 \%)$ \\
\hline Unavailable & Unvl & $\begin{array}{l}\text { Unable to see students continuously due to full } \\
\text { schedules. Long wait to make appointments and to } \\
\text { be seen even with a schedule appointment. }\end{array}$ & $11(42 \%)$ \\
\hline $\begin{array}{l}\text { Conflicting } \\
\text { Information }\end{array}$ & ConfInf & $\begin{array}{l}\text { Receiving different information from each } \\
\text { counselor visited. }\end{array}$ & $9(35 \%)$ \\
\hline
\end{tabular}

${ }^{*} n=26$

Lack of caring. The most commonly mentioned negative community college counseling experience was related to counselors' lack of caring. The majority of participants $(n=24,92 \%)$ indicated that general counselors did not genuinely care about them or their personal welfare (Refer to Table 21 above). Participants claimed that general counselors were often overly focused on the academic aspects of students' college experience that they rarely took the time to learn about their personal lives. Adela said, "They ask you everything like your name is? You're here for? Your major 
is? Or, let me check your banner and that kind of stuff. No personal questions" $(6 / 27 / 12$, Question 13). Similarly Yvonne added,

Counselors don't take the time to know if a student has children, or has a husband, or has three jobs. They don't ask about students' lives" (Question 10). They're more business-like, kind of like here and out the door type of thing. They're just like very serious like here's what you need, these are the classes, here you go, and that's it. Like not how've you been? Is there anything going on? Or do you think this is gonna fit well with your schedule' type of thing. Just not personable at all (Yvonne, 9/26/12, Question 11).

Participants also mentioned that they felt that general counselors did not care about them because they saw them and treated them as numbers and did not encourage them to return for follow-up counseling appointments. Alexzander mentioned, "They see me as a number, they don't see me as a person, like oh next one come in. They don't genuinely care about the results that they're gonna bring to me" $(9 / 20 / 12$, Question 11). Similarly Yadira shared, "Siento como que el estudiante va y viene y como que al consejero no le interesa que pasa contigo. [I feel like the student comes and goes and like the counselor doesn't care what happens to you] (6/25/12, Question 16). Genesis added, "I feel like counseling here is dry. You're there and then you're not and they don't care if you come back" (6/21/12, Question 19).

Overall, participants revealed that general counselors were not welcoming which made them feel that counselors did not care about them. "Counselors up there in 
admissions aren't very nice nor welcoming" (Anahi, 9/25/12, Question 11). "It's just the way they present themselves and their answers . . . like when they roll their eyes or are rude" (Esperanza, 9/17/12, Question 13). "They make you feel like you're bothering them, like they don't want to be there" (Jessica S., 9/12/12, Question 13). "Seeing their big ol' face makes you feel so intimidated that you forget what you were going to ask, what you were there for, and you just want to get out" (Marisol, 9/18/12, Question 11). Aside from feeling that general counselors did not care about students because they were unwelcoming, treated them like numbers, and were unwilling to get to know them or encourage multiple counseling visits, participants also indicated constantly feeling rushed during their counseling appointments.

Rushed counseling appointments. The second most commonly mentioned negative community college counseling experience was related to counseling appointments being rushed or "like a doctor's office” (Marisol, 9/18/12, Question 15). Seventy-seven percent of participants $(n=20)$ mentioned that their counseling appointments were always done in a hurry (Refer to Table 21). "It's like bam boom. Now you're in the counseling office, now you're done, now you can go on with your day. It's just too fast” (Genesis, 6/21/12, Question 13). “They're so business-like I guess. It's like get in, get them out, move on to the next one so we can get our days done in our nine to five job" (Faith, 9/13/12, Question 18).

Feeling rushed during counseling appointments caused frustration among participants. As first-generation students who were often new to the college and had no 
other source of information, participants often had many questions for counselors. One participant indicated, "I wanted so much information because I didn't know anything and I needed a lot of help. But they were just very basic and didn't really want to explain things in detail "cause they were in such a hurry" (Anahi, 9/25/12, Question 13). Thus, in many cases participants left their counseling appointment with many questions unanswered due to feeling rushed. Yadira mentioned, "El proceso es tan rápido que hasta uno se siente de prisa. A veces uno hasta se le olvidan las cosas que iba a decir porque se siente uno en ritmo rápido. Uno seguido se tiene que ir sin respuestas. [The process is so fast that you even feel in a hurry. You even forget the things you were going to say because it's so fast paced. You often have to leave without answers]" (Yadira, 6/25/12, Question 20).

Participants also expressed waiting longer to see a counselor than the time they actually spent in the counselor's office. In many cases, the long wait coupled with the rushed appointment often left participants feeling that the counselor had not met their needs and that they were not important.

When I went to counselors over there in admissions, it took me like more than half an hour to see them. When I was finally there, I was there for like 10 or 15 minutes max and I had to be out. It was like a rushed situation. It took me more to wait to see the counselor than what she actually helped me with (Fred, 9/21/12, Question 13). 
The rushed appointments and conversations with community college counselors often also led students to be placed into courses without being given the opportunity to engage in discussion about the most appropriate course of action.

Lack of options, thrown into classes. The third most commonly mentioned negative community college counseling experience was related to counselors' unwillingness to provide participants with details and explanations on course and career options. Over half of participants $(\mathrm{n}=18,69 \%)$ indicated that general counselors did not communicate to students the various course options and educational paths they had at the community college to meet their educational objectives (Refer to Table 21). Participants mentioned that anytime they sought assistance with academic planning and course registration, counselors often placed them into courses without (a) explaining why the course was needed or how it would fit with their goals, (b) considering their availability or their individual needs, or (c) giving them the opportunity to express their opinion about the proposed schedule of classes.

Participants felt that rushed counseling appointments often led counselors to ignore their requests and choose courses that they personally believed were a fit for them. Jessica S. indicated, "I feel like sometimes they don't try to listen to what you're trying to say. Like I say oh I want to take this class and they kind of push it and say no and want to choose for you" (9/12/12, Question 9). Yadira said,

La consejera que yo vi, fue muy rápida. Ella me buscó las clases y no me pidió opinión ni me dio opción. Solo me dijo que eran clases generales y que de todas 
maneras las tendría que tomar algún día. [The counselor I saw was too fast. She chose my classes and didn't ask for my opinion or give me options. She just told me that they were general classes and that I would have to take them some day anyway] (6/25/12, Question 19).

Participants also felt that the majority of the time, they were thrown into classes without being given much explanation.

The counseling up at the administration, they don't really care. They kind of just throw you in whatever and don't see how hard it's gonna be for you. They're kind of just oh here is the classes, I did my job, now next student (Faith, 9/13/12, Question 13).

Participants revealed that rushed course placements with limited discussion on the specific demands of the course and its applicability to their goals, often caused them to be unsuccessful in passing their semester courses.

The first time that I met the counselor, I had no idea about what I needed to do . .. The counselor chose the classes for me and she didn't explain anything about the classes I was going to be taking or if they were going to be difficult. And since it was my first semester, I just trusted that she knew and I didn't think of looking at the classes I would be taking. So I didn't pass one of my classes (Emily, 6/27/12, Question 13). 
In addition, the lack of explanation on the various options available to participants often created confusion and ambiguity in regards to the steps they needed to take to meet their educational objectives (certificate/degree/transfer).

Cuando me reuní con la consejera, no me explicó bien que clases me hacían falta; no me dio opciones de que otras clases debería de tomar o que otras cosas tenía que hacer para poder llegar a la universidad. No me dijo cuando tenía que aplicar, ni todos los pasos que tenía que seguir. Uno se queda sin saber más o menos cuando llegaremos a nuestra meta. [When I met with the counselor, she didn't explain what classes I still needed, she didn't give me options of what other classes I should take or what other things I needed to do to get to the university. She didn't tell me when I needed to apply and all the steps I needed to take. One is left not knowing more or less when we will reach our goal] (Mario, 6/26/12, Question 13).

According to participants, when counselors ignored their requests, their individual needs, and pushed them to take courses without having ample discussions about their options and their opinion, they inadvertently expressed that they did not care about students' success in college. Participants also mentioned blatant discouraging experiences with their community college counselor as described below.

Discouraging statements. The fourth most commonly mentioned negative community college counseling experience was related to participants feeling discouraged by counselors. Half of participants $(n=13,50 \%)$ indicated that general 
counselors often discouraged them from pursuing their goals (Refer to Table 21). In fact, participants expressed that general counselors judged their ability to succeed in college based solely on their assessment test scores.

When I took the assessment test here, I think I scored in the lowest. When the counselor saw my scores, he went on by saying that college wasn't a place to fool around and that I had to do my work. I felt that because I didn't do so well on that test, he thought I wasn't a good kid and was acting like a tough guy toward me because I didn't do good on that test. I felt he was judging me for what he saw on my scores. I just feel that that was unfair (Quetzalcoatl, 9/13/12, Question 13).

Participants also indicated that general counselors often had low expectations of them based on looking at their past performance in college courses and often expressed disregard about their abilities.

I've never seen such horrible counseling. In one case, I felt like I was talked to like I was stupid the whole time (Question 11). In another case, she was like oh you did badly in this class? How did you do bad? You're never gonna get into a four year college. Literally, like that, no joke (Alexzander, 9/20/12, Question 13).

Participants were also discouraged from pursuing their desired career path.

I went to a counselor and I told her I wanted to change from child development to RN. And she was basically discouraging me from doing nursing. She wasn't 
like, oh you can do it. She made it seem like it was gonna be so hard and like, 'why are you doing this' type of thing. She pretty much was trying to make me change my mind (Yvonne, 9/26/12, Question 13).

Participants who were currently or previously enrolled in the ESL program, were particularly discouraged from pursuing any other educational objective that required more than simply learning English. Alejandra mentioned,

Cuando recién empecé que quería sacar una carrera no nada más terminar ESL, fui con una consejera y me dijo, ¿pero para que quieres sacar una carrera? Tú solamente necesitas terminar el programa de ESL. ¿Cómo te vas a beneficiar si tienes hijos? Tú ya te tienes que quedar en tu casa a cuidarlos. Nomas tienes que aprender el inglés y es todo. Te quieren desanimar a que sigas estudiando. [When I first started to think that I wanted to obtain a career and not just finish ESL courses, I went to a counselor and she told me, why do you want to obtain a career? You just need to finish the ESL program. How are you going to benefit if you have kids? You need to stay home and take care of them. You just need to learn English and that's it. They want to discourage you from continuing your education] (9/20/12, Question 13).

Similarly, Cristina added, Una vez vine con una consejera y le dije que quería sacar mi AA degree, ella me dijo, ¿y porqué? ¿Para qué te preocupas en tanto? Nada más enfócate en sacar 
tu certificado ... Ella no me dio más información de cómo sacar el AA degree. Sentí como que a lo mejor no me ven lo suficientemente capaz para poderlo hacer. [One time that I came with a counselor and I told her that I wanted to get my AA degree, she said, for what? Why do you worry so much? Just focus on getting your certificate ... She didn't give me any more information about how to get an AA degree. I felt that maybe she didn't see me capable enough to do it] (Cristina, 6/28/12, Question 1).

Two ESL participants expressed that they felt that general counselors were racist against ESL students. "Es triste decirlo pero yo veo que si te miran que no hablas mucho inglés, hay racismo en como miran la capacidad de la persona. [It's sad to say, but I feel that if they see that you don't speak a lot of English, they are racist in the way they see the person's ability]" (Cristina, 6/28/12, Question 11).

According to participants, the discouraging statements they experienced from general counselors often made them doubt that they belonged in college and questioned their ability to complete their educational objectives. This uncertainty was also related to feeling that they often did not have access to a counselor on a continuous basis due to counselors' lack of availability as described below.

Unavailability. The fifth most commonly mentioned negative community college counseling experience was related to counselors' unavailability. Slightly less than half of participants $(n=11,42 \%)$ indicated that general counselors were unavailable to see students on a continuous basis due to their busy schedules (Refer to Table 21). 
"Their schedules are always full so it's really hard to see a counselor right away. Sometimes I have to wait 2 or 3 weeks to see my counselor because she's so busy" (Emily, 6/27/12, Question 13).

Participants further explained that even when they were finally able to schedule an appointment with a general counselor, they often still experienced a long waiting period before they were seen.

I scheduled an appointment and there was no one in the reception office and I just sat there waiting. Finally a lady came to ask if I was there for counseling. I told her I had been there for a while and I didn't know where my counselor was. She said that the counselor was going to be in, in half an hour. Instead of helping me because she was obviously available, she just walked back into her office. So what sucked was the waiting period even though I had an appointment. It made me feel inferior because here I am trying to get something and I wasn't able to do that. I was stuck and felt as if my time wasn't important (Genesis, 6/21/12, Question 13).

Participants revealed that due to counselors' limited availability, they often found themselves seeing different counselors every time they visited the counseling department. As a result, they faced the negative experience of "never seeing the same counselor and having to tell their story over and over again" (Adela, 6/27/12, Question 13) before they actually received the assistance they needed. In other cases, the lack of 
continuity in counseling also caused participants to receive conflicting information as described below.

Conflicting information. Receiving conflicting information from general counselors was a negative community college counseling experience mentioned by $35 \%$ of participants $(n=9)$ (Refer to Table 21). According to participants, each counselor they visited often had a different answer to the same question. "You go to one and they tell you something. You go to another and they tell you something else" (Jessica C., 9/12/12, Question 8). This variation in information caused frustration among participants because they often left their counseling appointment "más confundidos que cuando entraron a la oficina del consejero [more confused than when they entered the counselor's office]" (Yadira, 6/25/12, Question 13).

On a few occasions, the varying messages received from multiple counselors caused participants to fall short in the general education courses that were necessary to receive their associate's degree. Receiving conflicting information not only caused participants to postpone their graduation, but it also made them doubt counselors' credibility.

Un consejero me dijo que ya podía agarrar mi AA y a la hora de la hora otro me dijo que me hacía falta una clase que es la que tuve que tomar este verano para poder graduarme (Question 13). Entonces, uno siempre está con la duda de que, ¿que si todavía me falta? ¿ ¿que si voy por el camino que no debo? No haya uno ni a quién creerle. Causa frustración cuando tú estás pensando algo 
que el consejero te dijo y luego otro consejero te lo cambia, ya te cambia tus planes mentalmente. [A counselor told me that I could get my AA and it turned out that another counselor told me I needed another class which is the one I had to take this summer to graduate. So, you're always wondering, what if I still need classes? Or what if I'm not on the right path? You don't know who to believe. It's frustrating when you're thinking about something a counselor told you and then another counselor changes it. That changes your plans mentally] (Cristina, 6/28/12, Question 18).

Overall, all participants in this study $(\mathrm{n}=26,100 \%)$ indicated having a negative community college counseling experience with general counselors, while only one participant indicated having a negative experience with her categorical program counselor. Participants' negative community college counseling experiences were based on their perception that their counselor (a) lacked caring, (b) rushed them during counseling appointments, (c) provided them with no options and threw them into classes, (d) discouraged them from pursuing their goals, (e) was unavailable, and (f) gave them conflicting information (Refer to Table 21). Although these negative community college counseling experiences often kept participants from visiting counselors, participants also mentioned three other hindrances to seeking counseling services as described in the next section. 


\section{Students' Hindrances to Seeking Community College Counseling Services} Question 14: Has there been anything that keeps you from meeting with a college counselor?

The three hindrances to seeking counseling services most frequently mentioned by participants included (a) lack of time (69\%), (b) fear (62\%), and (c) doubt (54\%) (Refer to Table 22 below).

Table 22

Hindrances to Seeking Community College Counseling Services

\begin{tabular}{lclc}
\hline Category & Code & Code Definition & $\begin{array}{c}\text { Number of } \\
\text { Responses* }\end{array}$ \\
\hline $\begin{array}{l}\text { Lack of } \\
\text { Time }\end{array}$ & NTm & $\begin{array}{l}\text { Not having enough time to see a counselor due to school/work } \\
\text { schedule and/or transportation difficulties. }\end{array}$ & $18(69 \%)$ \\
Fear & Fr & $\begin{array}{l}\text { Fear of being: (a) questioned, (b) scolded, (c) pressured to do } \\
\text { more than able to handle, (d) discouraged from pursuing goals, } \\
\text { (e) unable to communicate, and (f) revealed (break in } \\
\text { confidentiality). }\end{array}$ & $16(62 \%)$ \\
Doubt & Dbt & $\begin{array}{l}\text { Doubt of counselors' ability to help and offer "genuine" } \\
\text { wisdom. }\end{array}$ & $14(54 \%)$ \\
\hline$* n=26$ & & &
\end{tabular}

It is important to note, however, that the hindrances to seeking counseling mentioned by participants varied based on whether or not they were part of a support program. As indicated below in Table 23, participants who were part of categorical support programs most frequently mentioned lack of time $(n=10,91 \%)$ as an obstacle to seeking counseling services while only one participant mentioned fear and doubt as something that kept her from meeting with her program counselor. In contrast, all participants who were not part of any support programs overwhelmingly mentioned fear $(n=15,100 \%)$ and doubt $(n=13,87 \%)$ as hindrances to seeking counseling services while slightly over half mentioned lack of time ( $n=8,53 \%)$ (Refer to Table 23 below). 
Table 23

Participants' Hindrances to Seeking Counseling in Support Programs vs No Support Programs

\begin{tabular}{cccc}
\hline Hindrance & In Support Program* & No Support Program ${ }^{* *}$ & Total $^{* * *}$ \\
\hline Lack of Time & $10(91 \%)$ & $8(53 \%)$ & $18(69 \%)$ \\
Fear & $1(9 \%)$ & $15(100 \%)$ & $16(62 \%)$ \\
Doubt & $1(9 \%)$ & $13(87 \%)$ & $14(54 \%)$ \\
\hline
\end{tabular}

${ }^{*} \mathrm{n}=11 ; *^{*} \mathrm{n}=15 ;{ }^{* * *} \mathrm{n}=26$

Lack of time. Lack of time was the most frequently mentioned obstacle to seeking counseling services. In fact $69 \%$ of participants indicated that they often did not have time to make an appointment with a college counselor due to their busy school and work schedule and/or difficulties with transportation $(n=18)$ (Refer to Table 22).

Participants expressed that they struggled with the demands of attending class, doing homework, and going to work. Thus, they often struggled to find any extra time in their schedule to meet with a counselor.

A lot of the times I have to be at school or I have to be at work. Like right now I'm taking six classes so I have to spend a lot of the time on homework, commuting, work, and more homework. Right now I'm working 30 hours, so it's just hard to make time (Esperanza, 9/17/12, Question 14).

In many cases, participants felt torn between the need to see a counselor, their responsibility to show up to work on time, and meeting their class requirements.

I work nine to five. I have to go to school and then I have to go straight to work. So basically when I go see a counselor, it's at the beginning of the semester when I know I have a little bit of time to meet with them. I mean, I know I can 
make time, but I think it would harm me if I don't get an extra hour of my school because I work Monday through Friday and sometimes Saturdays nine to five and on top of that I have school and homework (Yvonne, 9/26/12, Question 14).

Time constraints were even more prevalent for participants who had children. One participant indicated, "It's hard because I go to school, I have my son, and I have to work to pay the bills (Question 1). My schedule is limited . . basically I only have certain time to meet with a counselor" (Anahi, 9/25/12, Question 14).

Finally, time limitations were also common for participants who relied on public transportation to get to school. The sporadic bus arrivals, early bus departures, and the long bus rides home hindered participants from finding an appropriate counseling appointment time that didn't conflict with class, bus, and/or work schedule. Ernesto mentioned, "I have to take the bus home and here. So if I do want to meet with a counselor I only have an hour between my last class and the last bus that leaves here" (9/24/12, Question 14). Jade added, "como yo no manejo y tengo que tomar el camión, pues me toma mucho tiempo para venir a una cita. [Since I don't drive and I have to take the bus, it takes me a long time to come to an appointment]" (9/20/12, Question 14). Aside from time constraints, fear was also a factor that prevented participants from seeking counseling services. 
Fear. Over half of participants (62\%) indicated that fear prevented them from seeking counseling services $(n=16)$ (Refer to Table 22). Participants indicated a fear of being: (a) questioned, (b) scolded, (c) pressured to do more than able to handle, (d) discouraged from pursuing goals, (e) unable to communicate, and (f) revealed (break in confidentiality).

Da un poco de miedo. Te sientes como cohibida al momento de que tu consejera solamente hable un idioma, que tal vez no le vayas a entender, o que te quiera desanimar. También creo que da un poco de miedo que te vayan a regañar si preguntas algo o quieres cambiar tu plan. Más que nada creo que la parte dificil es poder expresarte de una manera que sepas que va a ser confidencial. [It's a little scary. You feel intimidated when your counselor only speaks one language, that maybe you won't understand her, or that she'll want to discourage you. I think it's also a little scary that they might scold you if you ask something or if you want to change your plan. More than anything, I think the hard part is being able to express yourself in a way that you know will be confidential] (Isabel, 9/25/12, Question 12).

Aside from fear, participants also mentioned doubt as something that prevented them from seeking counseling services.

Doubt. Slightly over half of participants (54\%) mentioned doubt as a hindrance to seeking counseling services $(\mathrm{n}=14)$ (Refer to Table 22). Having had multiple 
negative community college counseling experiences, participants often doubted counselors' ability to help and offer genuine wisdom regarding any academic and/or personal concerns.

I doubt that counselors will be able to help. With my experiences, now I'm thinking, What if they don't have anything beneficial to say? What if it's a waste of time? I don't want to schedule an appointment, go see a person and then it not be worth my while if they don't have any genuine wisdom or insight (Genesis, 6/21/12, Question 14).

Some participants indicated having lost hope in finding the counselor who would meet their needs.

I don't know if I'll ever find a good counselor. Right now I feel like what's the point of seeing a counselor 'cause I've seen several counselors and I'm not completely comfortable in going back to them. They're not welcoming and informative. They're just real quick, real brief. I don't know, I feel like they should be asking me questions because sometimes students don't know what questions to ask. Especially students that are new to community college (Sophia, 9/24/12, Question 13).

Overall, more than half of study participants mentioned lack of time, fear, and doubt as obstacles that kept them from meeting with a community college counselor (Refer to Table 22). These obstacles combined with their negative community college counseling experiences left $23 \%$ of participants $(n=6)$ wishing for a counseling session 
that was similar to their high school counseling experience. Participants indicated that compared to their experiences with college counselors, their high school counselor not only assisted them academically but was also concerned about their personal lives and about building a student-counselor connection.

I think that if college counselors were like high school counselors things would be different and there wouldn't be things to keep you from seeing them. My counselors in high school were just really helpful. There were a lot of us, but they knew all of us by name. We talked about everything. They just wanted to help us in any way possible. They were there to encourage us and support us. Now that I look back and think about it I still go to them because they're just so positive. I feel real comfortable in calling them and telling them about my problems and they're more than happy to talk to me about them. I don't feel like I can do that here right now ... I've already met with several counselors and there was no connection. I guess I have a higher standard for counselors because I had a lot of good ones in high school. So I guess I just expect a lot more (Sophia, 9/24/12, Question 14).

Given the positive and negative counseling incidents and the obstacles they faced in seeking counseling services, participants had some advice to offer community college counselors as described below. 


\section{Students' Consejos [Advice] for Community College Counselors}

Question 18: How would you change or improve community college counseling services?

Question 19: Is there anything else that you feel is important for me to know about your experiences with community college counselors?

Question 20: Do you have any advice for counselors who assist Latino college students?

Based on their experiences with community college counselors, participants indicated a need to improve counseling services in order to better serve first-generation, low-income, Latino students. Thus, participants offered consejos [advice] for counselors suggesting that they should (a) care more about students, (b) keep students informed, (c) show interest in assisting students, (d) provide bilingual services, and (e) be consistent in presenting information and assigning students to counselors (Refer to Table 24 below). 
Table 24

Participants' Consejos [Advice] for Community College Counselors

\begin{tabular}{|c|c|c|c|}
\hline Category & Code & Code Definition & $\begin{array}{l}\text { Number of } \\
\text { Responses* }\end{array}$ \\
\hline $\begin{array}{l}\text { Caring "Care More } \\
\text { about Students" }\end{array}$ & $\mathrm{Crg}$ & $\begin{array}{l}\text { Takes time, listens to concerns, focused on the } \\
\text { individual, builds connections, makes } \\
\text { individuals feel comfortable, and is patient, } \\
\text { encouraging, understanding, trustworthy, and } \\
\text { supportive. }\end{array}$ & $26(100 \%)$ \\
\hline $\begin{array}{l}\text { Information "Keep } \\
\text { Students Informed" }\end{array}$ & Infrm & $\begin{array}{l}\text { Provide information about counseling services } \\
\text { (location, ways to contact them, availability) and } \\
\text { other on-campus resources (financial aid and } \\
\text { scholarships). }\end{array}$ & $20(77 \%)$ \\
\hline $\begin{array}{l}\text { Interested "Show } \\
\text { Interest in Assisting } \\
\text { Students" }\end{array}$ & Intrst & $\begin{array}{l}\text { Showing interest in others' personal and } \\
\text { academic welfare, by (a) following-up via email } \\
\text { and/or phone and (b) encouraging multiple } \\
\text { visits. }\end{array}$ & $16(62 \%)$ \\
\hline $\begin{array}{l}\text { Bilingual "Increase } \\
\text { bilingual counseling } \\
\text { services" }\end{array}$ & Bilngl & $\begin{array}{l}\text { Has the ability to communicate with others } \\
\text { fluently in English and Spanish. }\end{array}$ & $14(54 \%)$ \\
\hline $\begin{array}{l}\text { Consistency "Provide } \\
\text { consistency in } \\
\text { counseling and } \\
\text { information" }\end{array}$ & Cnsist & $\begin{array}{l}\text { Consistency in information between counselors } \\
\text { and in ability to see the same counselor. }\end{array}$ & $11(42 \%)$ \\
\hline
\end{tabular}

Of the participants who were part of categorical support programs $(n=11)($ e.g., EOPS, MESA, Puente, TRIO), $91 \%$ of them $(n=10)$ mentioned that they had no advice for their program counselor. In fact, the advice that participants in support programs offered for the improvement of counseling services was specifically targeted for general counselors. In contrast, of the participants who were not part of any categorical support programs $(n=15), 100 \%$ offered advice for the improvement of general counseling services. 
Care more about students. All participants in this study $(n=26,100 \%)$ advised community college counselors to care more about students. Participants described a caring counselor as one who (a) took time, (b) listened to concerns, (c) focused on students, (d) built student-counselor connections, (e) made students feel comfortable, and (f) was patient, encouraging, understanding, trustworthy, and supportive (Refer to Table 24).

Participants expressed that counselors could be more caring by asking them about their personal and academic lives as opposed to solely focusing on the grades on their transcript. "I think counselors should be caring about your personal life as well as your academic life because they can be two completely separate sides of oneself" (Genesis, 6/21/12, Question 11). "It would be nice if you could go to your appointment and the counselor asked about your ed plan but also asked how you're doing and that they knew you by your first name" (Starlette, 6/21/12, Question 11).

Participants also mentioned that counselors could show students that they care by being willing to get to know them better. "Counselors should try to get to know the person a little bit ... even if it's just a few personal questions. Like, are you the first one to come to college? Or why did you decide to come to college?” (Jessica S., 9/12/12, Question 20) “Me gustaría que los consejeros preguntaran más de mi, de mi vida, y mi familia. [I would like counselors to ask more about me, about my life, and my family]" (Jade, 9/20/12, Question 18). 
In addition, participants indicated that counselors could express caring by being patient and willing to answer all questions. "I think it's really helpful for counselors to have patience, go step by step, and take more time with students" (Jessica S., 9/12/12, Question 9). "Como uno que tiene papás que no fueron a la escuela pues a veces necesitamos que nos ayuden más porque hay veces que no sabemos nada. [For those of us whose parents didn't go to college, sometimes we need more help because sometimes we don't know anything]" (Jade, 9/20/12, Question 20). "Aparte, es importante que los consejeros no se agobien con tanta pregunta porque pues uno solamente quiere estar bien informado y sentirse en confianza de hacer preguntas de todo. [Besides, it's important that counselors don't get overwhelmed with so many questions because we only want to be well informed and feel confident to ask all kinds of questions]" (Alejandra, 9/20/12, Question 20).

Moreover, participants indicated that counselors could demonstrate caring by encouraging students to continue their education and to not give up. "I think that counselors need to motivate students . . tell them that they're there to help ... and make them feel like they're not alone" (Fred, 9/21/12, Question 20).

Latino students need to be encouraged and followed throughout the time we are in college. I've noticed that for every person pushing a student to succeed and earn a degree, outside campus there's a bunch of people telling them to go back to work because it's worthless to get an education or that we came to this country to work and not waste time in school (Mario, 6/26/12, Question 20). 
Counselor encouragement was especially helpful for female participants who currently or at one point in their career were part of the ESL program $(n=5,100 \%)$ given the fact that going to college typically went against their cultural norms.

I think being Latino, we come from a background where whatever the men say that's what you're supposed to do. And sometimes you don't get anyone telling you that education is important. So you get comfortable being a mom. So counselors should encourage women to keep on going and become something else aside from being a woman at home. When they take that first step and make that choice to come to college, it's important that they meet with a counselor who knows their culture, knows their background, is welcoming, and who can motivate them and encourage them. That way they can see that it's possible (Marisol, 9/18/12, Question 19).

Finally, participants indicated that caring about students was about building student-counselor relationships, being genuine, and having heart. "To me it's really important to have some kind of relationship with counselors" (Starlette, 6/21/12, Question 19).

It's just all about genuine and having heart with the people that you see and it's about connecting with the individual (Question 19). Support is so few far and between that if students have one light, that one counselor can change their whole outlook if that counselor is really passionate about that one student. If they want that student to succeed they will. It's real. People can change people. 
A person can change their pattern of life and their whole way of thinking if one person believes in them and if a counselor can do that with a student then their whole life can be changed (Genesis, 6/21/12, Question 20).

Aside from advising counselors to care more about students, participants also advised them to keep students informed:

Keep students informed. An overwhelming majority of participants $(n=20$, $77 \%$ ) advised counselors to keep students informed. According to participants, keeping students informed involved providing information about counseling services (e.g., location, ways to contact them, availability) and other on and off-campus resources (e.g., financial aid and scholarships) (Refer to Table 24).

Of the participants who advised counselors to keep students informed, 50\% indicated a need to increase the information provided to students about the existence of community college counseling services $(\mathrm{n}=10)$. "I feel like we need more awareness that counselors are there" (Sophia, 9/24/12, Question 19). "Por ejemplo, muchos Latinos somos primera vez que venimos a la escuela y no sabemos que existen estos recursos de consejería [For example, for a lot of Latinos it's the first time we come to school and we don't know that these counseling resources exist]" (Mario, 6/26/12, Question 20).

For participants who immigrated from México to the United States after the age of $15(n=6)$, the need to know about the existence of counseling services was especially 
critical. "La gente piensa que todo mundo sabe de consejería, pero uno que no es de aquí no sabe. [People think that everyone knows about counseling, but for those of us who are not from here, we don't know]" (Cristina, 6/28/12, Question 9).

Yo creo que es importante que nos informen sobre los servicios de consejería sobre todo por nosotros que venimos de otro país. Es muy diferente la estructura de educación de México a la de aquí. Cuando llegué de México yo nunca había escuchado de los servicios de consejería (Question 9). Sería bueno que hubiera más información sobre donde o cuando o que hacer para contactarte con un consejero. Tal vez que pusieran en el muro de la página de internet, o tener volantes o folletos, o poner letreros en el salón donde todo mundo pueda ver que hay servicios disponibles. [I think it's important to inform us about counseling services especially for us who come from another country. The educational structure in México is very different from the one here. When I first came from México, I had never heard about counseling services (Question 9). It would be good if there was more information about where, when, and what to do to contact a counselor. Maybe have them put it on the website, or have flyers or pamphlets, or post signs in the classroom where everyone can see that there are services available] (Isabel, 9/25/12, Question 18).

Participants also indicated that community college counselors needed to advertise their services and their availability by (a) posting flyers, posters, and/or signs in classrooms 
and on campus, and (b) conducting classroom presentations. "I feel like counseling should be advertised in the school so that students know that counselors are available to help students to get a degree or move on to a university" (Quetzalcoatl, 9/13/12, Question 20). "Maybe have a description of what counselors can do" (Ernesto, 9/24/12, Question 20). "Maybe teachers could go over the flyers or posters in class to let students know that there are counselors available" (Yvonne, 9/26/12, Question 18). "Or counselors can come into the classroom personally so that students can recognize their face and feel more comfortable going to them for help" (Mario, 6/26/12, Question 20). Moreover, participants expressed that counselors needed to inform students about on-campus and off-campus resources without assuming that students have prior knowledge about the services available to them. "Counselors should tell everyone about everything just in case they don't already know" (Genesis, 6/21/12, Question 16). "Falta que los consejeros den más información sobre los programas que tienen para nosotros, las opciones que tenemos, ayuda financiera o los diferentes programas que hay en el colegio. [Counselors need to give more information about the programs available for us, our options, financial aid, or different programs that are available at the college)" (Yadira, 6/25/12, Question 20). "It would also be nice to have some community resources available. Maybe like a list of daycares or food resources, or just a phone number to call" (Starlette, 6/21/12, Question 18).

Participants especially emphasized the need for counselors to inform students about financial resources available to assist them with the high costs of attending 
college. "I think that a lot of first-generation low-income students are here because they don't have money for a four-year institution. So I think counselors should recommend scholarships ... and give them financial help that could possibly aid the burden of tuition" (Esperanza, 9/17/12, Question 20). Aside from advising community college counselors to keep students informed, participants also advised them to show interest in students.

Show interest in students. Over half of participants $(62 \%)$ advised counselors to show interest in students' personal and academic welfare by (a) encouraging multiple counseling visits and (b) following-up through email and/or phone ( $\mathrm{n}=16)$ (Refer to Table 24). "I wish counselors just took their time and seemed to be more interested in the student" (Anahi, 9/25/12, Question 19). "We need more friendly and caring counselors who show they're interested in us by asking about our personal life so that we don't feel that they're just here for a paycheck" (Quetzalcoatl, 9/13/12, Question 20).

Of the participants who advised counselors to show interest in students $(n=16)$, over half $(\mathrm{n}=9,56 \%)$ expressed that counselors needed to encourage multiple visits. "If they really want to help, they should encourage you to come and meet with them" (Alexzander, 9/20/12, Question 12). "Me gustaría que saliera de ellos de decirnos ven cuando quieras, no que nosotros nada mas cuando necesitáramos algo fuéramos. [I'd like for it to come out of them to say come whenever you want, not just for us to go to them when we need them]" (Jade, 9/20/12, Question 18). "Like kind of motivate 
students to come back and not just be like, here's an ed plan, here are the classes you need to take, if you don't have to come see me then don't" (Emily, 6/27/12, Question 20).

Moreover, of the 16 participants who advised counselors to show interest in students, $50 \%$ of them $(\mathrm{n}=8)$ mentioned that counselors needed to be required to followup with them through email and/or phone at least two times per semester. "I think keeping in contact is the best thing the counselor can do with students because they're letting them know that they're still interested in helping them" (Lili, 6/29/12, Question 20). "Counselors should take five minutes out of their hectic schedule and shoot an email to students" (Starlette, 6/21/12, Question 18).

Even just an automated message would be cool . . . like 'hi student, I'm really glad I had a chance to meet with you. Here is my email. If you have any questions and if you ever need academic counseling or someone to listen to you here is my email, here's my hours (Genesis, 6/21/12, Question 18). Overall, participants felt that counselors could show interest and increase their connection with students by checking-in with them on a continuous basis in an effort to: (a) review their progress, (b) keep them informed, (c) encourage them to return, and (d) give them advice and motivation to assist them in reaching their goals.

I know it's not high school to hold your hand, but you get stuck sometimes ... Counselors should encourage you to contact them if you have any problems and guide you step by step to overcome anything (Question 9). It would be better if 
they scheduled you another appointment in three months to follow up to see how your classes are going or stuff like that (Yvonne, 9/26/12, Question 18). Yo creo que si el consejero se mantuviera en contacto conmigo, eso me daría más confianza para seguir viéndolo y me motivaría a seguir adelante con mis metas porque sentiría que podría contar con su apoyo en cualquier cosa que se me pudiera atravesar. [I think that if the counselor kept in contact with me, I would feel more comfortable seeing them and it would motivate me to continue moving forward with my goals because it would make me feel that I could count on his support with anything that could come up] (Mario, 6/26/12, Question 19). Aside from advising community college counselors to show interest in students, participants also advised them to offer more services to students.

Increase bilingual counseling services. Slightly over half of participants $(\mathrm{n}=14,54 \%)$ indicated that bilingual counseling services needed to be increased (Refer to Table 24). In fact, being bilingual was one of the eight characteristics that participants believed were important for a counselor to possess (Refer to Table 15). Participants expressed that it was important for first-generation, low-income, Latino students to encounter other Latino counselors on the college campus who were Spanishspeaking and who understood their culture. "Si la mayoria de los estudiantes somos de habla Hispana, sería bueno que hubiera más consejeros que hablaran el idioma español. [If most students are Spanish speaking, it would be good to have counselors who spoke Spanish]" (Cristina, 6/28/12, Question 11). "Si los consejeros hablan 
español, te pueden comprender, entender tu cultura, y de dónde vienes. [If counselors speak Spanish, they can understand you, your culture, and where you come from" (Dulce, 9/18/12, Question 20). "If counselors know more about students' culture, their background, and their language then they can find better ways to approach students to make them feel comfortable to express themselves and come back to see them" (Marisol, 9/18/12, Question 19).

Participants emphasized that it was especially important to have Spanishspeaking counselors available to students whose primary language was Spanish or who had recently immigrated to the United States "I think it's important to have counselors who speak Spanish especially for those of us who English is their second language or who just recently came to this country" (Adela, 6/27/12, Question 20).

I could not imagine how negative the experiences of those that don't speak English must be. If I don't have glowing experiences with counseling and I'm immersed in the American culture, I can't imagine how someone just moving here and never been to college before would feel without having more Spanishspeaking counselors available. That's why it's extremely important to have Spanish-speaking counselors who can make it known that they speak Spanish. Just like bank tellers, counselors should have a sign outside their door to let students know they're Spanish-speaking (Genesis, 6/21/12, Question 19). Overall, participants indicated that having more Spanish-speaking counselors who understood their cultural background and could relate to their life experiences 
would increase their (a) ability to communicate (b) comfort in returning to seek counseling services, (c) trust in the counselor, and (d) likelihood of developing a student-counselor relationship.

Son contados los consejeros que realmente saben bien el español. Necesitamos consejeros que realmente sepan hablar, leer, y escribir el español para podernos comunicar de una mejor manera. Creo que eso nos ayudaría mucho porque tendriamos más en común, nos podríamos entender más, confiariamos más en ellos, nos relacionaríamos más, y nos animaríamos más a venir y buscar ayuda. Porque uno a veces se siente cohibido de buscar ayuda al pensar que te vas a encontrar con alguien que medio sabe tu idioma o que no lo sabe para nada. Definitivamente necesitamos más consejeros Latinos y de habla Hispana que puedan ser nuestros modelos y guías para poder lograr nuestras metas. [There are few counselors who really know Spanish well. We need counselors who really know how to speak, read, and write Spanish so that we can have better communication. I think that would help us a lot because we would have more in common, we could understand each other better, we could trust them more, relate to them more, and be more likely to come and seek help. Because sometimes we're fearful to seek help thinking that you'll encounter someone who kind of knows your language or who doesn't know it at all. We definitely need more Latino Spanish-speaking counselors who could be our role models and guides so that we can achieve our goals] (Isabel, 9/25/12, Question 18). 
Aside from desiring more Latino Spanish-speaking counselors, participants also expressed a need for consistency in information and counseling services.

Provide consistency in counseling and information. Slightly less than half of participants $(n=11,42 \%)$ expressed a need for consistency in the information they received from counselors and in their ability to see the same counselor (Refer to Table 24). Participants indicated a desire to be assigned to a community college counselor in order to: (a) receive consistent information and guidance, (b) obtain individualized counseling and follow-up services, (c) build a student-counselor relationship, and (d) connect with someone who is knowledgeable about the college process and who can encourage and motivate them to complete their educational objectives. However, participants emphasized that being assigned to a counselor also had to involve the flexibility and option of switching to a different counselor even if it meant having to go through an appeal process.

The following quotes illustrate students' perspectives about the benefits of being assigned to a community college counselor. "Having a counselor assigned to you throughout the whole entire time you're at a community college would be better" (Rob, 6/21/12, Question 18). "That way you don't have to keep telling counselors your story over and over again" (Jessica S., 9/12/12, Question 18). "Seeing the same counselor would allow you to see that one person you can know and can know you and that can help you with academic and personal concerns" (AJ, 7/2/12, Question 18). "Sería de más beneficio tener un consejero para poder formar una relación. [It would be more 
beneficial to have one counselor in order to build a relationship]" (Cristina, 6/28/12, Question 18). “Así el consejero ya sabe más o menos tus ideas, tus sueños, y tus metas y te puede motivar y ayudar de una mejor manera para que puedas lograr tus metas. [That way the counselor more or less knows your ideas, your dreams, and your goals and he can motivate and help you in a better way so that you can achieve your goals]" (Dulce, 9/18/12, Question 18). "But I would probably recommend that we have flexibility because you don't want to get stuck with a counselor you don't like. We also need to have options" (Adela, 6/27/12, Question 18).

Overall, based on their life experiences and their positive and negative encounters with community college counselors, participants advised counselors to (a) care more about students, (b) keep students informed, (c) show interest in assisting students, (d) provide bilingual services, and (e) be consistent in presenting information and assigning students to counselors. Participants expressed that in following their advice, first-generation, low-income, Latino community college students would be more likely to feel supported and motivated to complete their educational objectives and reach college success. "It's those small things that count. Those small things really do add up, they show the character of a person and whether or not they really want to help out somebody in being successful in college" (Alexzander, 9/20/12, Question 12). The following section delineates the grounded theory model that offers a visual representation of the study findings. 


\section{Theoretical Model for Students' Perspectives of Community College Counseling}

The use of qualitative grounded theory research in this study specifically emphasized: (a) observing the world through the eyes of participants while developing concepts and theories that were grounded in multiple stages of data collection, (b) generating an explanatory theory that emerged through constant comparative analysis, and (c) making predictive statements about the experiences of participants that were grounded in the data (Cresswell, 2008; Glaser, 2003; Glaser \& Strauss, 1967).

Using grounded theory allowed the researcher to use the (a) information from the literature review to guide the data collection and analysis, and (b) process of constant comparisons to better organize the raw data into meaningful sets of events and re-occurring themes. The mechanics of emerging concepts coupled with continuous parallels to the literature create a synthesis of thought and a goal of contributing theory of knowledge at the conclusion (Glaser \& Strauss, 1967). According to Glaser and Strauss (1967), theory is a process that is ever-developing rather than a perfected product. By implementing a qualitative methodology in combination with a grounded theory design, the researcher was able to (a) listen to the voices of Latino community college students as they shared their experiences on how they perceived, negotiated (interpret or try to make meaning of), and developed the relationship with their community college counselor, (b) freely search for constant new ideas and elements, and (c) develop theories based on themes encountered in the data collection process. 


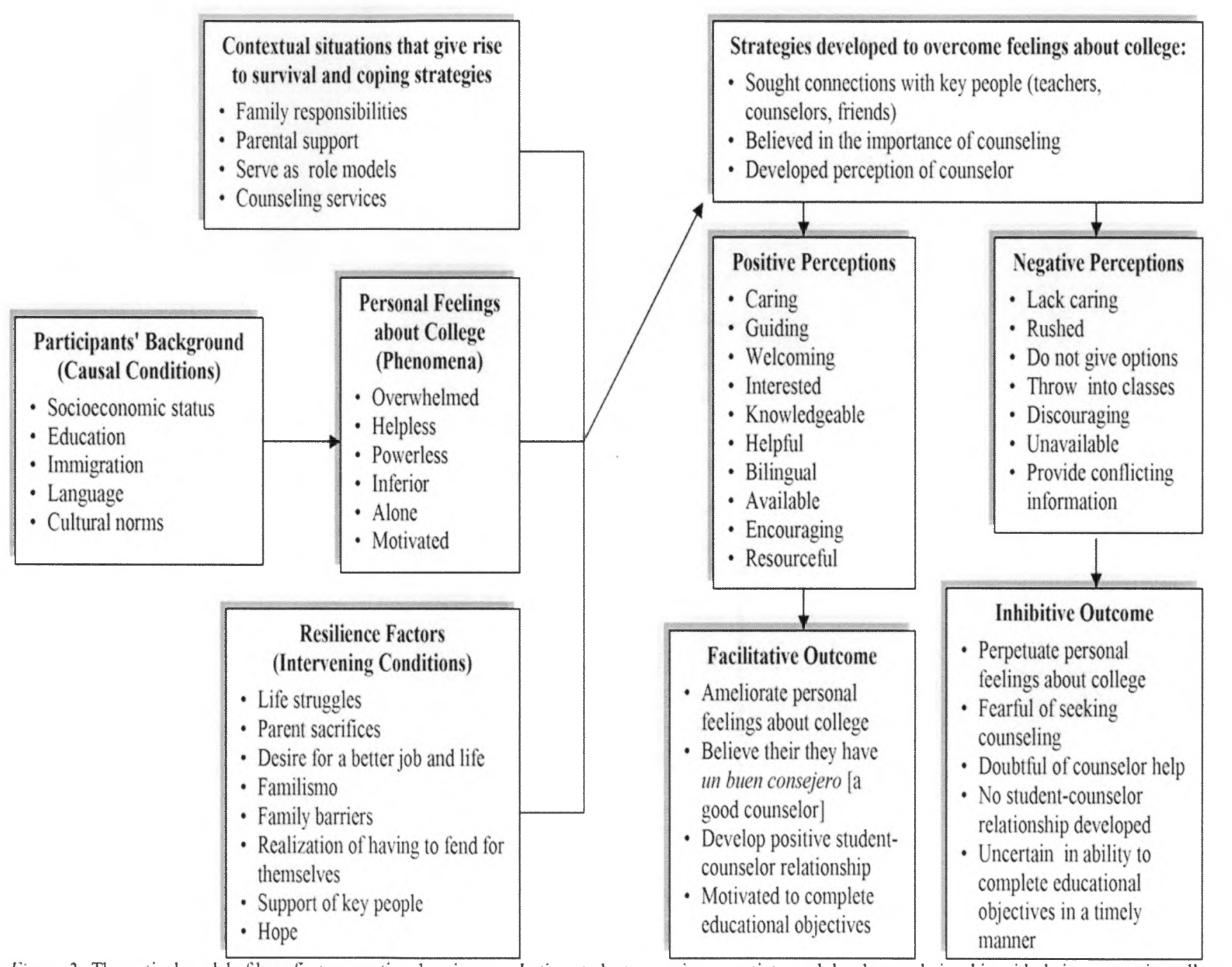


As illustrated in Figure 2 above, there were various causal conditions, or variables that led to the development of the phenomena, derived from participants' background that included having to cope with (a) low socioeconomic status, (b) limited levels of education, (c) immigration, (d) Spanish being the primary language, and (e) various cultural norms (e.g., familismo, personalismo, machismo, marianismo, respeto). Coming from a family background that involved such conditions ultimately led to the phenomenological experiences or personal feelings about college including feelings of being overwhelmed, helpless, powerless, inferior, and alone. However, participants still felt motivated to navigate through the community college system in an effort to reach their educational objectives to improve their lifestyle and become role models.

Strategies were developed by participants to overcome their personal feelings about college. The development of these strategies was influenced by particular contextual situations (personal life circumstances) and resilience factors (methods of coping). The contextual markers that influenced the strategies developed by participants to overcome their feelings of being overwhelmed, helpless, powerless, inferior, and alone included: (a) family responsibilities, (b) parental support and advice, (c) a desire to serve as role models, and (d) community college counseling experiences. In addition to context, there were also intervening conditions or resilience factors that influenced participants' choices to overcome their personal feelings about college. Resilience factors included (a) life struggles, (b) parent sacrifices and advice, (c) a desire for a better 
job and life, (d) familismo (family support) (e) family barriers, (f) a realization of having to fend for themselves, and (g) hope.

In the presence of the contextual situations and resilience factors described above, various strategies were developed by participants to survive and cope with their personal feelings about college or the way they saw their schooling experience. Participants were likely to seek connections with key people on the college campus who could provide them with hope, motivation, empowerment, and inspiration needed to reach their educational objectives. In fact, $96 \%$ of participants mentioned counseling as one of the most critical support services for their academic success. Based on their counseling experience, participants developed their perception about their community college counselor. Participants perceived their community college counseling experience as positive if they believed their counselor was caring, guiding, welcoming, interested, knowledgeable, helpful, bilingual, available, encouraging, and resourceful. In contrast, negative community college counseling perceptions were based on participants' belief that their counselor lacked caring, rushed, did not give options, threw them into classes, discouraged, was unavailable, and provided conflicting information.

As demonstrated in Figure 2, participants developed strategies and perceptions that led to either a facilitative or an inhibitive outcome. Facilitative outcome: participants who had positive perceptions about community college counseling services expressed (a) ameliorating their personal feelings about college, (b) having un buen consejero [a good counselor], (c) being able to develop a positive student-counselor relationship, and (d) 
feeling more motivated to complete their educational objectives. Inhibitive outcome: participants who had negative perceptions about community college counseling services expressed (a) a perpetuation of their personal feelings about college, (b) fear of seeking counseling services, (c) doubt in counselors' ability to help, (d) inability to develop a student-counselor relationship, and (e) uncertainty in their ability to complete their educational objectives in a timely manner.

\section{Conclusion}

Pursuing higher education for the completion of a degree was an important goal that all participants in this study $(n=26,100 \%)$ wanted to accomplish. Participants were specifically motivated to attend college based on (a) the struggles they experienced growing up, (b) parental sacrifices and advice, (c) their desire for a better job and a better life, and (d) their aspiration to become role models for their siblings and/or their children. This motivation to attend college was found to be highly supported by their familia [family] including their parents, siblings, and extended family.

Mothers and husbands were found to be especially supportive of participants' pursuit for higher education. Participants indicated that their mother demonstrated their value and support for education by consistently (a) asking them about their classes, (b) dismissing them from doing household chores, (c) staying up late to keep them company during late night assignments, and (d) providing advice, encouragement, financial help, and babysitting assistance. On the other hand, husbands primarily provided financial support for participants to attend college. 
Although Latino families were found to be very supportive of participants' pursuit of a college education, they were often unable to support them due to their limited education and overwhelming work responsibilities. Thus, counseling services were found to be pivotal in supporting students with their academic and personal concerns. In fact, the majority of participants in this study $(n=25,96 \%)$ described counseling services as very important or important, while only one student described counseling as not important.

Participants indicated that counseling services were especially crucial for firstgeneration students who typically felt lost and confused about the college process and could not rely on their parents or other family members for guidance and assistance. They further explained that community college counseling services were fundamental for them to be able to (a) receive individualized and step-by-step guidance, (b) obtain support and encouragement, (c) solicit and verify information, and (d) gain the motivation needed to complete their educational objectives. However, participants mentioned that they preferred meeting with counselors who possessed the characteristics of what they perceived to be un buen consejero [a good counselor].

Participants perceived un buen consejero [a good counselor] as one who was: (a) caring, (b) welcoming, (c) interested, (d) knowledgeable, (e) helpful, (f) bilingual, (g) available, and (h) able to guide students in the right direction. Participants whose counselors possessed the characteristics un buen consejero [a good counselor] were more likely to describe their counseling experience as positive than participants whose 
counselor did not possess such characteristics. Out of the total study sample $(n=26)$, more than two-thirds of participants $(n=18,69 \%)$ expressed that they had a positive experience with community college counselors. Positive counseling experiences were related to counselors being caring $(65 \%)$, interested in their personal and academic welfare $(62 \%)$, and being willing to help them with anything necessary $(58 \%)$ and teach them about important websites and resources available for their use (46\%).

Of the participants who indicated having a positive counseling experience, over half $(n=10,56 \%)$ were part of categorical support programs (e.g., EOPS, MESA, Puente, and TRIO) while $44 \%$ were not part of any programs $(n=8)$. The majority of participants in categorical support programs with the exception of one $(n=10,91 \%)$, overwhelmingly expressed high satisfaction with their program counselor and described their counseling experience as more positive and different from their counseling experience prior to being part of the support program. Participants especially emphasized the (a) caring encounters they experienced with their counselor, (b) interest their counselor demonstrated in their personal and academic success, and (c) desire of their counselor to help and teach. In contrast, only $53 \%$ of participants who were not part of any special support program described their counseling experience as positive. Although participants who expressed having positive counseling experiences also described their counselors as being caring, interested, and willing to help and teach, they specifically highlighted four counselors at their community college. 
Participants also described negative community college counseling experiences. All participants in this study $(n=26)$, indicated having had a negative community college counseling experience. These negative counseling experiences were primarily in reference to general counselors. In fact, of the total study sample $(n=26)$ only one participant indicated having had a negative experience with her categorical program counselor compared to $100 \%$ of participants who indicated a negative counseling experience with a general counselor. Participants' negative community college counseling experiences were based on their perception that their counselor (a) lacked caring, (b) rushed them during counseling appointments, (c) provided them with no options and threw them into classes, (d) discouraged them from pursuing their goals, (e) was unavailable, and (f) gave them conflicting information (Refer to Table 21).

Although negative community college counseling experiences often kept participants from visiting counselors, participants also mentioned lack of time on their end (69\%), fear (62\%), and doubt (54\%) as hindrances to seeking counseling services. Counseling-seeking hindrances varied based on whether participants were in support programs or not. Participants who were part of categorical support programs most frequently mentioned lack of time on their end (91\%) as an obstacle to seeking counseling services while only one participant mentioned fear and doubt as something that kept her from meeting with her program counselor. In contrast, all participants who were not part of any support programs overwhelmingly mentioned fear (100\%) and doubt 
$(87 \%)$ as hindrances to seeking counseling services while slightly over half mentioned lack of time on their end (53\%).

These obstacles combined with their negative community college counseling experiences left $23 \%$ of participants $(n=6)$ wishing for a counseling session that was similar to their high school counseling experience. Participants indicated that compared to their experiences with college counselors, their high school counselor not only assisted them academically but was also concerned about their personal lives and about building a student-counselor connection. Thus, in an effort to improve counseling services to better serve first-generation, low-income, Latino students, participants suggested that counselors should (a) care more about students, (b) keep students informed, (c) show interest in assisting students, (d) provide bilingual services, and (e) be consistent in presenting information and assigning students to counselors.

Although participants who were part of categorical programs more frequently expressed having positive community college counseling experiences than participants who were not part of any programs, the results of this study indicate that students' perceptions about community college counseling were related to the specific characteristics, presence, and interactions of the counselor with whom they met. The results revealed that regardless of whether or not participants were part of a categorical program (EOPS,MESA, Puente, TRIO), they were more likely to perceive their community college counseling experience as positive if their counselor: (a) possessed the characteristics of un buen consejero [a good counselor], (b) cared about them as if they 
were family, (c) demonstrated interest in their personal and academic welfare, (d) helped them with anything necessary, (e) taught them about important websites and resources available for their use, (f) encouraged, motivated and supported them, and (g) developed a positive student-counselor relationship.

Overall, this chapter addressed the research question associated with this study by allowing us to hear the voices of 26 first-generation, low-income, Latino community college students as they shared their life struggles and community college counseling experiences in their pursuit of higher education. The next chapter (chapter five) provides a discussion about the outcomes, implications, and recommendations of this study. Chapter five is organized into seven sections including: (a) study overview, (b) interpretation of findings, (c) limitations of the study, (d) implications, (e) recommendations for action, (f) recommendations for further study, and (g) reflections on the research process. 